DEEORA ZAMARIOLI

Cartografia de um Corvo em Cena:

Ertraçẽ e Codificaçñ de Matrizes Corvorais através do método Eody Mind Centeringo

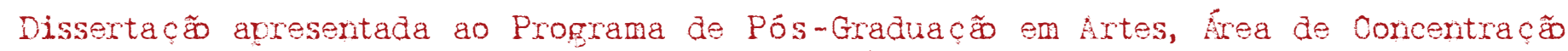
Pedagogia do Teatro, Linha de Pesquisa Formaç̃ do Artista Teatral, da Escola de Comunicações e Artes da Universidade de Sẽ Paulo, como exigencia varcial vara obtençõ do Título de Mestre em Artes, sob a orientaçäo do Prof. Dr. Armando Sérgio da Silva.

Sผ̃ Paủo

2009 
DÉBORA ZAMARIOLI

\title{
Cartografia de um Corpo em Cena: \\ Extração e Codificação de Matrizes Corporais através do método Body Mind Centering ${ }^{\circledR}$
}

\begin{abstract}
Dissertação apresentada ao Programa de Pós-Graduação em Artes, Área de Concentração Pedagogia do Teatro, Linha de Pesquisa Formação do Artista Teatral, da Escola de Comunicações e Artes da Universidade de São Paulo, como exigência parcial para obtenção do Título de Mestre em Artes, sob a orientação do Prof. Dr. Armando Sérgio da Silva.
\end{abstract}


Zamarioli, Débora.

Cartografia de um corpo em cena: extração e codificação de matrizes corporais através do método Body Mind Centering® / Débora Zamarioli. -- São Paulo: USP / Escola de Comunicação e Artes, 2009.

xi, 104p.; il.; $31 \mathrm{~cm}$.

Orientador: Prof. Dr. Armando Sérgio da Silva

Dissertação (mestrado) - Universidade de São Paulo, Escola de Comunicações e Artes, CAC, 2009.

Referências bibliográficas: f. 105 - 109

1. Teatro. 2. Extração e codificação de matrizes. 3. Princípios do método BMC®. 4. Pedagogia do Teatro - Tese. I. Silva, Armando Sérgio. II. Universidade de São Paulo, Escola de Comunicações e Artes. III. Título. 


\section{AGRADECIMENTOS}

À minha querida e amada família que sempre apoiou meus caminhos, minhas decisões e meus desejos. Muito, muito obrigada!

Ao encorajador Prof. Dr. Armando Sérgio da Silva que orientou e confiou no meu trabalho, amparando-me nos momentos difíceis da pesquisa e compartilhando as felizes descobertas.

Àqueles que fazem ou fizeram parte do CEPECA e acompanharam generosamente todo o processo.

Às minhas grandes amigas e companheiras de trabalho Isis Madi e Sandra Pestana que sempre estão dispostas a compartilhar um café com pãozinho e se lançarem no risco da criação.

À minha querida Renée Bressan que dividiu muitas das suas horas em longas conversas sobre teatro, dança, arte, vida...

À Adriana Almeida Pees que me iniciou nesta jornada e me apresentou os princípios do Body Mind Centering ${ }^{\circledR}$.

À antiga Zero Zero Cia de Teatro que acreditou em seus sonhos, despertou meus anseios e me mostrou que “cara feia é fome!”.

Ao amigo Diego Martinez que, pacientemente, me deu aulas de manipulação de objetos, escutou e incentivou muitas idéias mirabolantes.

Ao querido Pedro Hurpia que aconselhou, fotografou, colaborou e acompanhou de perto todas as crises e alegrias do processo.

A todos os meus amigos amados que carinhosamente viram ensaios, conversaram, fomentaram e beberam as dificuldades de uma atriz-pesquisadora.

Ao Samir Signeu e Gabriel Catelani que confiaram no meu trabalho e me deram a oportunidade de expandir a pesquisa com alunos-atores.

Aos meus alunos que, dia-a-dia, me ensinam a arte da partilha e da entrega.

Ao Marcelo Comparini que, atenciosamente, editou o material audiovisual, e que, sem saber, fundou as bases para este trabalho. 
Ao Tiago Spagnuolo que incansavelmente me acompanhou durante as idas e vindas à rua 25 de março a procura de objetos e idéias para o espetáculo.

À Renata Vendramin que gentilmente escutou meus pensamentos em pleno café da manhã!

À Verônica Fabrini que me mostrou que o ser humano é, antes de tudo, belo!

Ao Renato Ferracini que, generosamente, colaborou com a formulação deste projeto e, sensivelmente, me encorajou a arriscar.

À Rosely Rodrigues que zelosamente revisou e traduziu meus textos.

À FAPESP que acreditou e financiou a pesquisa, possiblitando minha integral dedicação aos estudos. Aos atenciosos professores e funcionários da USP.

Sou muito grata a todos! 
À Cristina, José Paulo e Paula Zamarioli, meus amados pais e irmã. 
"Pode ser que eu tenha nascido com um corpo atormentado, ilusório como a imensa montanha; mas é um corpo cujas obsessões servem para alguma coisa; e percebi, na montanha, para que serve a obsessão de contar. Não houve sombra que eu deixasse de contar ao vê-la dando voltas ao redor de alguma coisa; e muitas vezes foi somando sombras que cheguei até estranhos lugares”. (ARTAUD, 1983, p. 98)

“- O que é 'sabedoria corporal'?

- Tudo o que você precisa saber está aí, dentro de você. Os segredos do universo estão gravados nas células do seu corpo".

(...)

“A compreensão é unidimensional. É a compreensão pelo intelecto que leva ao conhecimento. A percepção, por outro lado, é tridimensional. É a compreensão simultânea da cabeça, do coração e do instinto. Ela provém unicamente da experiência pura”.

(MILLMAN, 2000, p. 26-27) 


\section{RESUMO}

Este projeto está intimamente ligado à criação artística do ator, suas abordagens, reflexões e métodos. Ele está no âmbito da pesquisa do corpo cênico, de seus movimentos e de sua continua (re)significação perante quem o assiste e, por sua vez, da sua própria (re)organização.

Para isso, cartografei meu próprio processo de aprendizagem e criação através dos diálogos entre o método de educação do movimento, Body Mind Centering ${ }^{\circledR}$, inicialmente desenvolvido pela americana Bonnie Bainbridge Cohen, das formas de extração e codificação de matrizes corporais mapeadas por Renato Ferracini, e dos princípios da performance estudados por Renato Cohen.

Assim, o desafio desta pesquisa foi a utilização do material perceptivo, proveniente da prática corporal, para a elaboração cênica. Ou seja, transcrever as sensações em matrizes codificadas, visando uma apresentação final em que este procedimento fosse (in)visível.

Palavras-chave: teatro, interpretação, BMC ${ }^{\circ}$, processo de corporificação, sistemas corporais, matriz, punctum, espaço do corpo. 


\begin{abstract}
The present project is closely linked to the artistic creation of the actor, his approaches, thoughts and methods. The project is located in the realm of the research of the scenic body, its movements and its continuous (re)meaning in the face of the spectator and, on its turn, facing its own (re)organization.

To achieve my goal I mapped our own learning and creation process through the dialog between the method of educating the movement, called Body Mind Centering ${ }^{\circledR}$, firstly developed by Bonnie Bainbridge, through the method of extracting and encoding the body matrixes mapped by Renato Ferracini, and through the performances studied by Renato Cohen.

Therefore, the challenge of the present research was the use of perceptive material, deriving from the body practice used to build the scene. That means, translate the sensations into coded matrixes, aiming a final presentation where the said procedure would be (in)visible.
\end{abstract}

Key words: Theater, interpretation, $\mathrm{BMC} \AA$, body building process, body systems, matrix, punctun, body space. 


\section{SUMÁRIO}

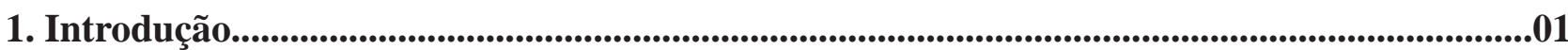

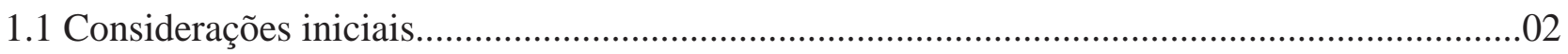

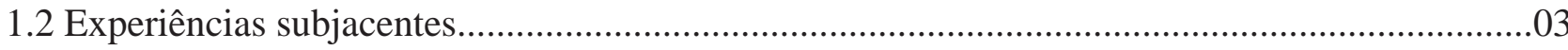

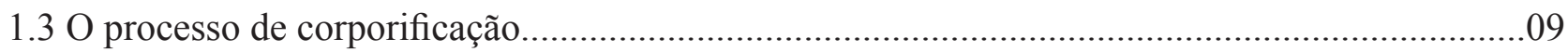

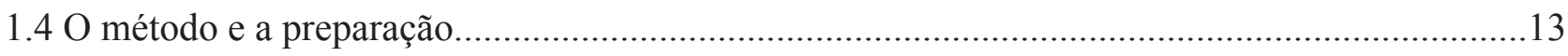

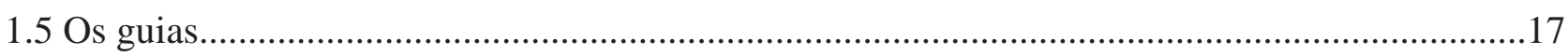

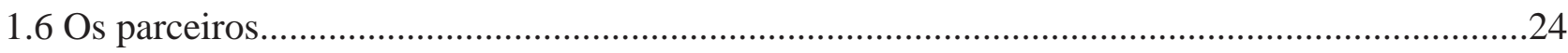

2. A Preparação..............................................................................................................................25

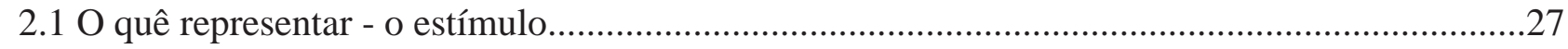

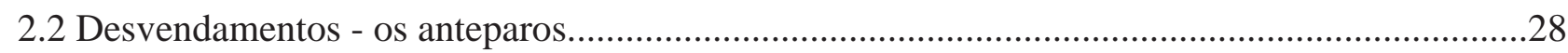

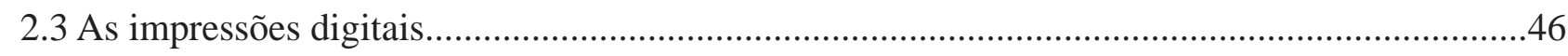

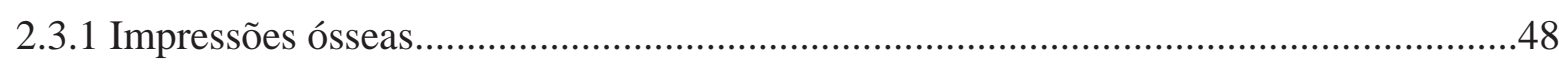

2.3.2 Impressões orgânicas..................................................................................................60

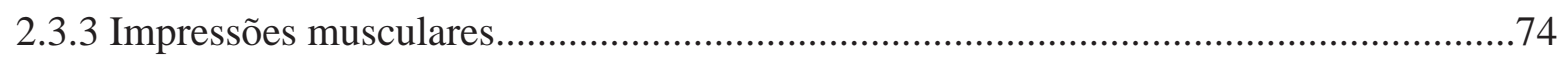

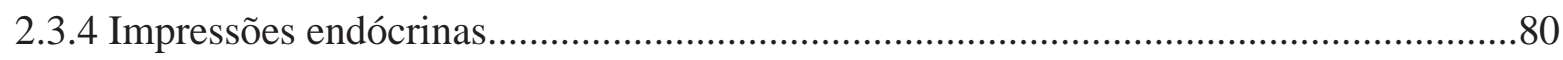

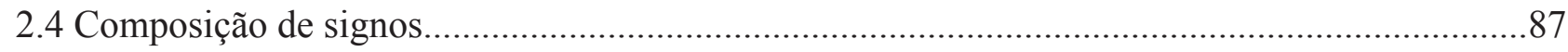

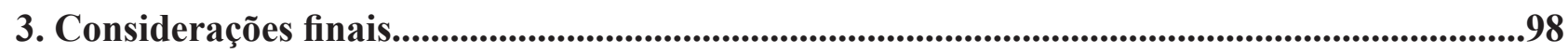

Bibliografia.................................................................................................................................................................105

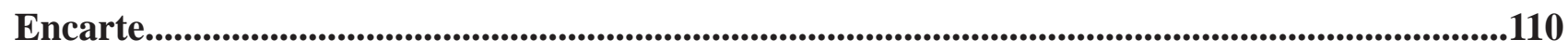

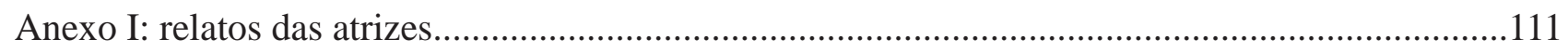


Anexo II: Ana-me... 


\section{INTRODUÇÃO}

“Tecer a rede é construir uma ponte entre nós, como somos habitualmente em condições normais, trazendo conosco nosso mundinho de todo dia, e um mundo invisível que só pode se revelar quando a insuficiência da percepção ordinária é substituida por outro tipo de consciência cuja qualidade é infinitamente mais aguda".

(BROOK, 2005, p. 72) 


\subsection{CONSIDERAÇÕES INICIAIS}

O trânsito entre palavras escritas, faladas e sentidas é um exercício registrado nessa dissertação. A tentativa de refletir sobre a própria prática da cena traz consigo a intrínsica e subjetiva relação entre sujeito-objeto, pois se trata de encontrar estratégias para conceituar a própria experiência-em-arte que teima em ser silenciosa e sem palavra.

Narrar a experiência do próprio corpo-em-arte é também uma experiência. Portanto, as palavras e suas disposições espaciais foram contaminadas pelo processo, aqui, contado. Capaz de abrigar a não-linearidade, a não-hierarquia, a transitoriedade, as lacunas, os insights, o não saber, a intuição, e outras possibilidades inerentes à experiência, o conceito de rizoma nos influenciou na preparação do texto.

De acordo com Deleuze, o rizoma “(...) não começa nem conclui, ele se encontra sempre no meio, entre as coisas, inter-ser, intermezzo. A árvore é filiação, mas o rizoma é aliança, unicamente aliança. A árvore impõe o verbo "ser", mas o rizoma tem como tecido a conjunção "e... e... e..." Há nesta conjunção força suficiente para sacudir e desenraizar o verbo ser. Entre as coisas não designa uma correlação localizável que vai de uma para outra e reciprocamente, mas uma direção perpendicular, um movimento transversal que as carrega uma e outra, riacho sem início nem fim, que rói suas duas margens e adquire velocidade no meio”.

(DELEUZE, 1995, p. 36)

Assim, ao desenharmos o texto "rizomaticamente", ganhamos a liberdade para escrever, experimentando, trocando, afetando. Similarmente à prática, a escrita, também, é exposição, travessia e risco. Aqui, nos expomos em: vermelho, gráficos, figuras, setas, vazios, questionamentos, comentários, citações, poesia, transparências, entre linhas, etc.

Todas as intervenções são "e...e...e...". Acreditamos que essas conjunções somam e formam conjuntos híbridos que auxiliam a percorrer o riacho sem início nem fim da criação-em-arte. Entretanto, auxiliar a travessia não é paralizar o fluxo da água ou limitar o significado, mas sim, prover bóias, bolhas para mergulhar ou suspender a experiência. 


\subsection{EXPERIÊNCIAS SUBJACENTES}

Como cheguei ao tema dessa pesquisa de mestrado? Quais foram os parâmetros para a escolha da bibliografia, da linha de pesquisa, dos itens de avaliação? Como perceber o próprio processo criativo?

Essas perguntas só foram possíveis depois de experiências com mestres, amigos, colegas de trabalho, amores, sonhos e decepções. Todas essas vivências são, hoje, minha base e meu apoio para todas as reflexões acerca do trabalho do ator, do pesquisador e do criador.

A vida uterina desse projeto se deu em Barão Geraldo, distrito de Campinas, onde se localiza a Unicamp

L "Ooservando o desenvolvimento do feto e do bebê, vodemos ver vadrões subjacentes que se refletirão em todos os níveis do desenvolvimento". (HARTLEY, 1995, 0. 25)

- local onde cursei artes cênicas e conheci a "Turma Zero Zero", assim chamada pois seus membros ingressaram na universidade no ano de 2000.

Não irei, aqui, narrar os felizes e intensos momentos da graduação que embora não estejam tão distantes, já são capazes de despertar relevante nostalgia. Lá encontrei amigos, professores e artistas que marcariam L Se o "Ser Piegas" rẽo fosse tẽo frágil e vulnerável, eu escreveria terna nostalgia... profundamente meu modo de ver a atuação e meus próprios padrões de percepção. Os diferentes olhares que atravessaram comigo a jornada de iniciação ao trabalho de ator, ajudaram-me a distinguir e entender as relações entre "dentro" e "fora", criando a consciência e a experiência do "limite". Durante quatro anos, estudamos, ensaiamos e treinamos exaustivamente para entender e ultrapassar nossos limites individuais e coletivos, e prazerosamente!

pois tínhamos o desejo de ser um grupo ao fim do curso. Portanto, tínhamos a tarefa de descobrir, identificar, articular, diferenciar e integrar nossas fronteiras. Éramos pequenas células que possuíam a mesma formação acadêmica e distintas especialidades. como um coroo unico". (EARDT e NEGRI, 2005, 0. 248)

Junto com outras colegas, respondi pela função de preparadora corporal do grupo. E, em 2004, nosso

primeiro ano como bacharéis em interpretação, iniciei meu desenvolvimento como atriz-pesquisadora responsável Habilidade de iniciax os próprios movimentos propositalmente, pela manutenção dos estudos e descobertas corporais da Zero Zero Companhia de Teatro. Intuitivamente, propus ao grupo um trabalho de consciência corporal, que eu não sabia para onde nos levaria. 
Descreverei cronologicamente vara facilitar a compreená̃o, mas, no
momento que acontecia, o vrocesso era mais caótico.

Primeiro ensaio: iniciar movimentos a partir de diferentes partes do corpo (cabeça, ombro, cotovelos, pés...). Selecionar os movimentos que julgarem interessantes e formalizar uma seqüência. Repetir. Repetir. E repetir.

Segundo ensaio: Retomar a seqüência elaborada. Descrevê-la verbalmente durante a execução com o máximo de detalhes e precisão. Aqui surge a primeira pergunta dos atores - descrever o que: os movimentos que o corpo faz no espaço ou as imagens criadas durante a execução dos movimentos? Foi uma grande surpresa, pois, na ocasião, eu não pensei nessa possibilidade de descrição imagética. Então separei em dois momentos - descrição dos movimentos em si (viro meu pé direito para fora enquanto faço trajetórias circulares no ar com mão esquerda) e descrição das imagens (caminho para a porta enquanto aceno um adeus triste ao meu passado).

A partir daqui, observo que existem diferentes padrões de criação em cada ator. E que eu deveria ficar atenta a eles.

"Eroerimentada através do sistema esquelético, a mente se torna estruturalmente organizada, vromovendo suoorte - avoio vara nossos vensamentos, alavanca vara nossas idéias, e dobradiças ou escaços vara a articulaça relaç̃ entre elas". (COHEN, 2008, 0. 2)

Terceiro ensaio: Propus a eles que tocassem seus ossos; com as mãos tocar a pele e, aos poucos, deixar os dedos penetrarem no corpo, atravessar os músculos, observar o sangue e chegar aos ossos. Depois de fazer isso em todo o corpo, retomar a seqüência. Minha segunda surpresa (e susto!) o estado corporal mudou. Alguns dançavam de forma mais ágil e precisa, outros experimentavam as possibilidades das articulações, e, ainda outros, brincavam com a imagem da caveira. Ou seja, cada um organizava e selecionava as informações comuns de acordo com seus próprios conhecimentos e experiências de vida.

Outros ensaios: Pesquisamos os ossos a partir do toque em si mesmo; da iniciação de movimentos; da ilustração dos ossos no próprio corpo com o auxílio de giz; e, sempre tentávamos transformar essas impressões em "cena", em "dança".

Todos os exercícios eram elaborados intuitivamente e, muitos deles, surgiam no momento do encontro, decorrente das qualidades de movimentos sugeridas pelos atores.

Senti que poderíamos mudar o foco da pesquisa e nos aprofundarmos em nossa conscientização corporal: partimos para a exploração dos órgãos.

"Quando rimos, choramos ou exolodimos de raiva, experimentamos essas emoçóes - um movimento vara fora - nos órgéos". (HARTLY, 1995, 巳. 183) 
"Mensageiro: Matou-se ela mesma. Fôste pouvado ao mais doloroso do acontecimento, por rö teres rada sob os olhos. Contudo, quanto me é possivel lembrar, saberás os sofrimentos daquela desditosa. No seu arrebatamento, mal transôs o vestíbulo, precioitouse diretamente à alcova nupcial; ia arrancando os cabelos com ambas as mõos. Entrou, bateu a porta após si, passou a chamar por Laio, há tantos anos morto; lembrou o filho entầ concebido, a cujas mãss Laio houve de morrer, deirando-a para mãe da vrole abominável do próprio filho dêle. Deplorava, a desverturada, o tálamo desdobrado onde gerou dum marido outro marido, dum filho, outros filhos. Como, depois, morreu fá rथ̃ sei dizer, porque Édioo irrompeu aos brados e rổ nos deirou assistir ao seu fim; tínhamos os olhos nêle, nas voltas que dava, indo e vindo a vedir lhe arranjássemos uma espada, a perguntar onde encontrar a espôsa, que rỗ era espôsa, mas desdobrada gleba maternal amanhada para si e para seus filhos. Algum nume o conduziu na sua fúria e rõo qualquer de nós que verto estávamos. Como se alguém o guiasse, soltando um grito horrivel, atirou-se de encontro às fôlhas da porta, fazendo os lemes saltar do vש̃ das fêmeas, e arrojou-se na alcova. Vimos, então, a mulher pendurada, enforcada nas voltas dum baraço. Mal o coitado a viu, deu um rugido medonho e desatou os nós do 1aço. Quando Jazeu no cín aquela misera, seguiu-se uma cena horrorosa. Éaido arrancou-The das vestes uns alfinetes de ouro que a adorravam, ergueu-se e com eles vazou os globos de seus próprios olhos, exclamando coisas horríveis; que fá ré poderiam ver os males que sofria, nem os que causava; no futuro veriam somente em trevas a quem rü deviam ver e rй conheceriam quem êle desejara conhecen. Enquanto gritava tais palavras, ia, rố uma, revetidas vêzes, levantando os alfinêtes e ferindo as páloebras. Enquanto isso, as pupilas ensangüentadas banhavam-Ihe as barbas; rõo era um gotejar de bagos úmidos, era uma chuva escura, um granizo de sangue que escorria".

$$
\text { (SÓFOOLES, 1968, ๖. } 83 \text { e 84) }
$$


Primeiro ensaio: Como nos ossos, experimentamos tocar os órgãos. Mas, dessa vez, esse exercício não foi tão simples... Muitos atores começaram a chorar e penetrar em algum lugar escuro e fundo; alguns comentaram que ficaram com medo de seguir e não conseguir encontrar o caminho de volta. Percebi a atmosfera que se instaurou e finalizei o ensaio com conversas sobre as experiências.

Segundo ensaio: Pedi aos atores tocarem os órgãos, mas, agora, com a visão de um cientista que perceberia suas características como o peso, a cor e o volume. Senti que precisava recuar as emoções para dar espaço para a própria fisicidade dos órgãos. A maioria conseguiu visualizar e perceber os órgãos. Mas de qualquer forma, o ensaio finalizou sem a experiência "cênica". Terceira surpresa: os tempos, ósseo e orgânico, eram diferentes.

Terceiro ensaio: Mais familiarizados e preparados, novamente tocamos os órgãos e conseguimos dançálos. As seqüências ganharam peso, volume, emoção e expressividade. Essa observação me levou a pensar nas relações entre diferentes sistemas corporais e gêneros dramáticos.

Outros ensaios: Depois da ativação do estado corporal proveniente do sistema orgânico, unimos os órgãos à tragédia grega. Escolhi a peça "Édipo Rei”, de Sófocles. Dividi os atores em grupos: masculino e feminino. Li o trecho em que é relatada a morte de Jocasta e as ações conclusivas de Édipo. Pedi aos meninos que improvisassem Édipo e às meninas, Jocasta. Foi surpreendente. Os atores conseguiram transformar as sensações dos órgãos em ações densas e emotivas. Em outro momento, para sentirmos os órgãos, utilizamos, além do toque, sacos plásticos cheios de água colorida e envoltos por óleo. Finalizamos e partimos para os músculos.

Primeiro ensaio: Conduzi uma série de exercícios de resistência e força unidos a um caráter de jogo. Os atores ficaram extremamente falantes, dispersos e, alguns, irritadiços. Mas, ao mesmo tempo, havia disposição e energia.

Segundo ensaio: Cheguei e pedi a eles que se aquecessem sozinhos, pois eu sairia e voltaria como outra pessoa, alguém que me substituiria e que conduziria o ensaio. Sentia que os atores precisavam mudar de atitude, ganhar tônus e ter a vontade de se mostrar para alguém desconhecido. Eles aceitaram o jogo e eu cheguei como "Denise" . Através dessa brincadeira pude exigir mais precisão, vitalidade e, ao mesmo 
tempo, mais concentração. Na época não sabia os motivos dessa proposta. Eu apenas seguia minha intuição. Atualmente, observo que foi uma forma de perceber em mim mesma o sistema muscular, pois é um sistema que posteriormente comecei a entender.

Terceiro ensaio: Estava muito frio dentro do espaço onde ensaiávamos, então conduzi o aquecimento do lado de fora, no sol. E, sem perceber, trabalhamos a pele e os sentidos. Depois, não consegui retornar aos músculos. Eu estava completamente perdida. Na época, não entendia que aqueles sinais de extroversão poderiam fazer parte da expressão e que poderíamos criar a partir disso.

Outros ensaios: A companhia estava com apresentações marcadas, substituição a fazer e pouco tempo para os ensaios. Então, interrompemos o processo nesse ponto. Acredito que a interrupção foi necessária para a reflexão e amadurecimento da pesquisa, pois chegamos a um ponto em que eu precisava experimentar e corporificar a própria pesquisa. Mas como? A quem ou a que técnica eu deveria recorrer? O que eu estava fazendo? Eu tocava os atores e era tocada por eles. Percebia-me no tempo e no espaço através desses movimentos recíprocos .

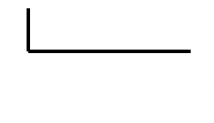
"A eroeriencia do toque é, cronologicamente e osicologicamente a háa dos Sentidos. Na evolucã dos
sentidos, ele é, sem dúvida, o orimeiro que avarece. (...) o toque, mais do que qualquer outra

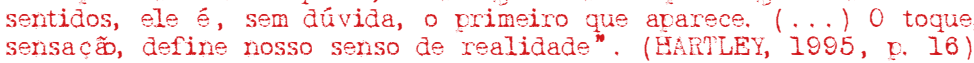

Mas já existiam percepções que guiariam minha busca e que se tornariam os principais objetivos dessa pesquisa:

- Estudar diferentes potencialidades criativas através do estudo dos sistemas corporais;

- Entender o corpo como um espetáculo em si;

- Codificar e transformar em material cênico as sensações percebidas durante o processo;

- Construir “personagens", personas ou figuras através da exploração e refinamento da percepção corpórea;

- Investigar formas de comunicação híbridas a fim de promover a criação entre o ator e o espectador;

- Refletir e conceituar o processo prático de criação cênica proveniente dessa percepção;

- Criar exercícios ou caminhos que auxiliem na formação do artista teatral;

- Buscar a autonomia de criação do intérprete.

Entretanto, ainda, não havia encontrado o procedimento metodológico capaz de envolver e abraçar minha intuição. Até que em 2006, conheci o método de educação do movimento desenvolvido incialmente 
por Bonnie Bainbridge Cohen, o Body Mind Centering ${ }^{\circledR}(B M C \circledR)$.

“O pensamento é como o vento e o corpo é como a areia: se você quer saber como o vento está soprando, você pode observar a areia.” (COHEN, B. B., 2008, p. 1)

Como a areia, o corpo se expressa por minúsculos pontos de afetividade, de singularidades, de devires. De acordo com Cohen, B. B., "nosso corpo se move como nosso pensamento. A qualidade de qualquer movimento é uma manifestação da forma de expressão do pensamento. Quando mudamos a qualidade do movimento, pedimos para nosso pensamento se rearranjar e mudar de foco no corpo. Inversamente, quando direcionamos nosso pensamento ou atenção para diferentes áreas do corpo e iniciamos movimentos a partir delas, mudamos a qualidade de nosso movimento. (...) No BMC®, 'centering’é um processo de equilíbrio, não um lugar para se atingir. Esse equilíbrio é baseado no diálogo, e o diálogo, na experiência. Um aspecto importante na jornada em BMC® é descobrir a relação entre o menor nível de atividade no interior do corpo e o maior movimento do mesmo - alinhando o íntimo movimento da célula e a expressão externa do movimento no espaço. Isto envolve identificação, articulação, diferenciação e integração de vários tecidos internos do corpo, descobrindo suas qualidades, contribuições e envolvimentos para o desenvolvimento do movimento externo; e os papéis que desempenham na expressão do pensamento. (...) Entretanto, o alinhamento não é um objetivo. É um diálogo contínuo entre conhecimento e ação - tornar-se consciente das relações existentes entre corpo/mente e agir a partir dessa consciência. Esse alinhamento cria um estado de sabedoria. (...) Nós somos os estudantes, o estudo e o professor.” (2008, p. 1)

Desta forma, o BMC® é uma prática que visa, entre outras coisas, entender o processo do pensamento, percebendo, conceitual e empiricamente, as relações entre a parte e o todo. Busca-se a organização, a articulação e a integração dos vários sistemas existentes no organismo, descobrindo a contribuição dos mesmos para cada qualidade de movimento do indivíduo e sua expressão sobre o pensamento. Utiliza-se conhecimentos da ciência ocidental e da filosofia oriental, no que se refere, principalmente, aos princípios de complementaridade e integração, (re)significando os próprios termos científicos. Deste modo, estuda-se a anatomia e fisiologia de um sistema corporal, percebendo seus processos e estados mentais e expressivos. Cada parte é detentora de expressão, poesia e conhecimentos únicos. No BMC® eles são estimulados através de técnicas de toque, 
visualização e movimentação.

Através do curso "Formação em Integração do Movimento Somático®", que utiliza os princípios do BMC ${ }^{\circledR}$ para a educação do movimento, ministrado e coordenado por Adriana Almeida Pees, BMC ${ }^{\circledR}$ practitioner, estudei aspectos dos sistemas ósseo, orgânico, muscular, fluído, endócrino, nervoso, sensorial e perceptivo; reflexos, reações de endireitamento e resposta de equilíbrio (RRR); e, padrões neurológicos básicos. A partir dessas vivências pude corporificar e "concretizar" minha intuição: os princípios do BMC ${ }^{\circledR}$ seriam os procedimentos metodológicos que guiariam a pesquisa.

\subsection{O PROCESSO DE CORPORIFICAÇÃO}

Para uma melhor compreensão do processo proposto pelo BMC®, utilizo as explicações e descrições contidas no artigo “The Process of Embodiment”. (COHEN, B. B., 2008, p. 157). Nele, entendemos que para o BMC®, a exploração da anatomia é um processo de corporificação. É um aprendizado dissolvido na consciência celular. No método, corporificar significa presença, claridade e sabedoria. Através de visualização e somatização, retornamos à pré-consciência com o pensamento consciente.

De acordo com o BMC®, o processo de corporificação é orientado por:

- "Visualização - processo em que o cérebro imagina aspectos do corpo, informando ao corpo que ele próprio existe. Nesse processo existe um guia. Depois de observar e mentalizar a imagem de uma determinada estrutura corporal, investiga-se essa imagem até que ela se localize e se transforme em corpo.

- Somatização - processo em que o movimento, a propriocepção e o toque informam que o corpo existe. Nesse processo existe uma testemunha, uma sabedoria interna. Percebe-se a sensação que emana de determinada parte do corpo através do toque ou do movimento; ou inicia-se o movimento por esse lugar e percebe as sensações e sentimentos que surgem. O que se nota? Quais são as sensações, sentimentos e percepções? Como isto afeta o movimento e a consciência?

- Corporificação - é o (re)conhecimento próprio das células. Deixa-se fluir. Let go of the conscious map. É uma experiência direta; não há passos intermediários ou transições. Não existe guia ou testemunha. 
Existe apenas a consciência total da experiência iniciada pelas próprias células. Nesse momento, o cérebro é o último a saber. Existe uma compreensão serena. Desta corporificação brotam sentimentos, pensamentos, testemunhos e entendimentos. A fonte desse processo é amor”. (COHEN, B. B.,2008, p. 157)

Assim, percebemos que primeiramente se focaliza a atenção na imagem, estimulando a sensação que ocorre no cérebro. Depois essa imagem se localiza no corpo e pode ser convidada à expressão através do toque ou do movimento. Então, esta percepção se torna corpo, corporificando-se. A chave está na sensação interna e no conhecimento das próprias células.

Observamos que existe um caminho facilitador e percepções diferenciadas entre a imagem e sua corporificação. O foco principal está na experiência direta das próprias células. De acordo com Cohen, B. B., "as imagens são mapas para a exploração. Não se deve colocar a atenção e a importância nos mapas, mas sim, na experiência em si. A atenção celular é uma sensação derivada da experiência direta que acontece nas células e não na mediação das imagens”. (2008, p. 157)

Entendemos esse estado criado pela consciência celular como um estado zen. Simplicidade e serenidade são palavras que nos remetem à impressão da magnitude da experiência direta entre o ser e o universo. Impressão, poucas vezes sentida, e muito almejada, em exercícios de improvisação.

Todas as células do organismo possuem a mesma estrutura e respiram . Mas cada uma possui sua especialidade (célula nervosa, cardíaca, muscular, etc). Quando o BMC ${ }^{\circledR}$ propõe experimentar a corporificação de determinada parte do corpo sugere, na realidade, o contato com a "memória ontológica". Ou seja, é trazer à consciência aquilo que já sabíamos profundamente, mas estava inconsciente. Ele considera que todas as células são memória. Memória da pele, do toque, do movimento. Acordamos o pensamento da célula especializada em simbiose, atravessada pela memória ontológica.

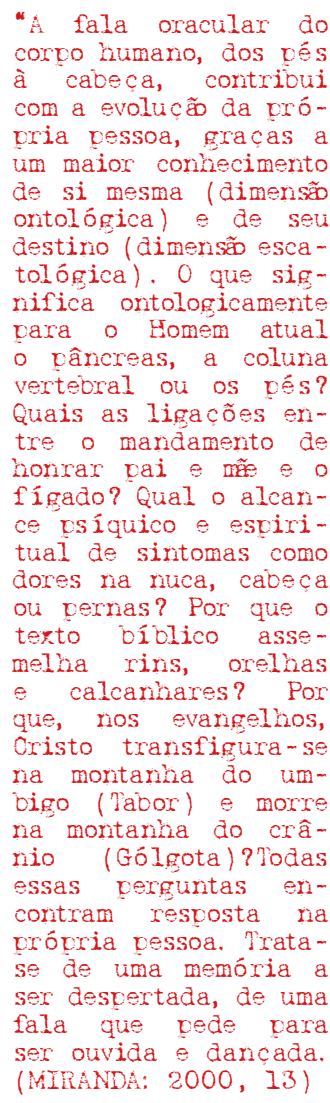

Aqui tratamos da estrutura celular em si. "Tođa a matéria viva é comoosta de células e todas as células são originađas a parti de células preeristentes, que contém as informações hereditárias dos organismos dos quais elas são uma parte. Essas afirmaçóes comó̃em a teoria celular que possui imolicacóes imoortantes como: ao estudar a biologia da célula, se está estudando a vida e, essa vida continua, de célula varental vara célula filha. Todas as células cossuem dois elementos essenciais: a memorana vlasmática, conhecida também oor vlasmalema ou memorana celular, que sevara os contéudos celulares do ambiente externo. E o outro é o material genético, que constitui a informaçó hereditária, que regula todas as atividades celulares e características que sĩ vassadas vara outros descendentes. $(\ldots$. .

Os componentes de célula, sem considerar o núcleo e a varede celular, quando vresentes, constituem-se do citoplasma e da membrana celular que o envolve". htto: / / ww ufmt. br / bionet / conteudos/15.07.04/morf_org. htm 
Para Cohen, B. B., os pensamentos conscientes e inconscientes são fluidos e flutuam, interpenetram-se o tempo todo e em todas as direções. Eles são um continuum do próprio pensamento ou da mente.

“Eles são a sombra ou suporte do movimento e da expressão um do outro. Quando expressamos um desses aspectos da mente mais do que o outro, ainda sim estamos ativos naquele”. (2008, p. 13)

No processo de corporificação, pensamentos conscientes e inconscientes dialogam, pois como define Cohen, B. B., “o BMC® é uma prática do jogo 'aprender - conduzir’' a sabedoria consciente e, depois, (re) absorvê-la profundamente até a inconsciência, entendendo a natureza essencial e a origem do conhecimento

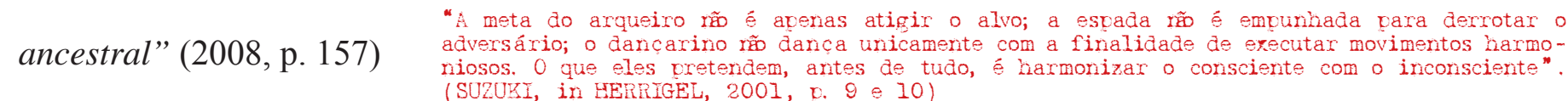

Podemos encontrar momentos claros do diálogo e da relação de apoio e mobilidade entre consciência e inconsciência em nosso próprio cotidiano de trabalho. Quantas vezes entramos em uma sala de ensaio sem saber o que fazer, e começamos a nos mover aleatoriamente... Até que, sem saber o motivo, acontece uma mudança. Esses movimentos se preenchem, engravidam e nos lançam para outro lugar dotado de objetividade subjetiva. Então a imaginação, a movimentação e o espaço fluem e respiram juntos. E, simplesmente, percebemos a forma que emerge da intuição.

Desta maneira, colocamos a atenção em nossa intuição e iniciamos os movimentos por ela, sem nos preocuparmos com sua localização. Aos poucos, ela ganha forma e desenha o espaço, caracterizando um padrão de movimento. Então, a criatividade ganha consciência, estrutura e localização.

Ou o contrário, quando temos um foco claro de estudo, como nos relata Naomi Silman, atriz-pesquisadora do Lume Teatro: “lembro-me de que na época dos ensaios com Tadashi (dançarino e coreógrafo de butoh que trabalhou e criou o espetáculo Shi Zen - Sete Cuias junto com o Lume Teatro) trabalhávamos exaustivamente com a imagem de estar pendurados, suspensos entre a terra e o céu, andando como se um fio tênue nos segurasse. No seguinte momento imaginávamos que esse fio era cortado e assim caíamos de repente no chão. O importante era não antecipar a "queda", fingí-la ou forçá-la, mas que ela acontecesse "de verdade”, num determinado momento preciso. Depois de um tempo bastante prolongado de repetição dessa dinâmica, cada um começou a entrar num ritmo de movimentos que não era mais conduzido por nossa mente racional, que tentava realizar o exercício, mas como se fôssemos conduzidos por uma música interna que tomava conta do 
nosso corpo e o guiava, sem a nossa vontade. (...) Tornando visível o invisível. O céu se encontrando com a terra”. (SILMAN, in FERRACINI, 2006 b, p. 49)

Se analisarmos pelo ponto de vista do diálogo entre pensamento consciente e inconsciente, verificamos que existia um procedimento, um exercício claro, uma "forma", e que, depois de muita repetição, ela deixou de ser racional ou consciente, atingindo a inconsciência e os fluidos. Ou seja, primeiramente sentimos e esmiuçamos cada movimento, seqüenciamento e forma, até que, de repente, percebemos que as próprias quedas e recuperações, como nesse relato, nos guiam na experiência. E, simplesmente, percebemos os pensamentos da própria forma. Transformamos a imagem, a forma e suas informações em sabedoria celular. Então, experimentamos a criatividade e pensamentos inerentes dessas células especializadas através da facilitação teórica, estrutural ou formal.

Em ambos os casos, a iniciação do movimento é um princípio fundamental e amplamente explorado no BMC®. Em uma experiência, selecionamos os impulsos que a iniciam, por exemplo: iniciamos, ora através dos sentidos, ora dos ossos, ora dos músculos, dos órgãos, das glândulas, etc. Para o BMC®, a iniciação do movimento é um princípio que não se restringe às articulações do sistema ósseo. Portanto, não se trata, apenas, de iniciação central, distal, medial ou proximal . O processo de corporificação admite a veracidade do conhecimento, das informações e do desejo originados de cada sistema, de cada parte.

Nesse sentido, compreendemos que cada sistema possui um pensamento, uma manifestação diferente. Como vercebi intuitivamente nas exoeriências realizadas com a consciência

No BMC®, esse pensamento é chamado de mind. Podemos compreendê-la como a presença ou energia das células do tecido. Daí a importância do entendimento desse princípio, pois podemos iniciar o movimento por qualquer sistema, reconhecendo seu pensamento e deixando-o influenciar e equilibrar outros sistemas. Através da sabedoria e ação consciente, podemos recuperar a interação dinâmica e o equilíbrio entre os sistemas corporais e suas qualidades.

"A iniciaç̃o e seqüenciamento de movimentos š̃o duas funcôes que organizam o movimento corooral considerando o imoulso inicial e sua continuidade. Uma mesma aç̃ pode ser realizada de maneiras totalmente distintas, dependendo de qual parte inicia e qual (is) parte ( $S$ ) dá ( dão) continuidade ao movimento".

$(\ldots)$

A Iniciacão imolica em qual varte do corvo lidera o movimento, e oode ser (Hackney, 1998: 240-1): Iniciacễ central ("Core") - a vartir do centro do coroo;

Iniciaç̃ ororimal "Prorimal") - a vartir das articulacóes vrorimais: corofemoral e escavuloneural;

Iniciacão medial (Mid-Limo") - a vartir dos cotovelos e joelhos:

Iniciacẽ distal ("Distal") - a vartir da cabeca, dos vés e das nóos.

Seqüenciamento imolica na continuidade da iniciaço de uma dada ação, e vode ser:

Simultâneo (duas ou mais partes movem-se ao mesmo temó)

Sucessivo (vartes adjacentes movem-se como que em uma onda, como o movimento de vértebra vara vértebra, ou do Centro

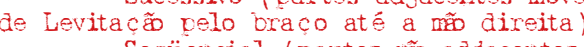

- Seqüencial (vartes rố adjacentes movem-se em sequida uma da outra, como mõ direita, cabeca, cé direito)". (FERNANDES, 2006 , v. $67-68$ 
Desta forma, experimentamos o caminhar e perguntamos: qual pé está em frente ao outro? como os ossos se acomodam? Experimentamos o comer: qual o gosto disto? qual a textura? A percepção se torna o centro, a pergunta chave, o pensamento principal: o que estamos percebendo. Entretanto, existe um momento em que se deve simplesmente andar e comer: agir. Há um ponto em que atingimos a consciência e, depois, "let

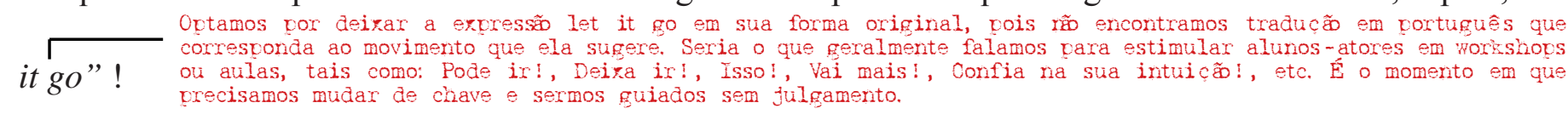

Notamos que existe uma relação de apoio e mobilidade entre perceber e agir, sentir e fluir. Como

Cohen, B. B. exemplifica, “quando se está em um ambiente desconhecido a primeira coisa que se faz é usar os sentidos; a percepção fica ativa em um lugar onde não se conhece os limites. Retarda-se os fluídos para ficar alerta. Mas se estivermos num momento de real perigo, e fizermos uma longa pausa para pensar, seremos aniquilados e morreremos. Simplesmente devemos agir, e nesse momento as percepções são inconscientes. Felizmente ganhamos habilidade sensorial suficiente que nos servirá de suporte para conseguirmos sobreviver”. (2008, p. 65)

Assim, podemos escolher o lugar onde se inicia a experiência e quais os princípios utilizados. O jogo produzido depende das relações de apoio e mobilidade entre os sistemas. Por exemplo, podemos mobilizar ou explorar o Sistema Muscular com o apoio do Sistema Circulatório, ou pela estabilidade do Sistema Nervoso, transformando seu pensamento, suas energias e sua presença. Ou seja, cada pensamento, presença ou mind sistêmica contribui, distintamente, para a qualidade do movimento. Eles são interdependentes, e juntos provem um oceano de expressão e suporte. De acordo com o método, alguns possuem afinidades naturais, entretanto, elas são particulares de cada indivíduo, grupo e cultura.

\subsection{O MÉTODO E A PREPARAÇÃo}

Nas palavras de Ferracini, “o ator busca, como artista, fazer com que o outro ser humano que o assiste se desorganize - se ressignifique - se reorganize. Para tanto, ele precisa, cotidianamente, desorganizar-seressignificar-se - reorganizar-se em sala de trabalho e na sua relação com seu público, tentando criar com o corpo um espaço outro, um tempo outro, um campo de intensividades”. (FERRACINI, 2006 a, p. 35, 36). 
Percebemos que, o trabalho do ator sobre si mesmo entende o próprio processo de aprendizagem como parte de seu ofício. Através de práticas e sistematizações constantes, o ator se potencializa na tentativa de construção do encontro entre humanidades (Grotowski).

O teatro é feito por pessoas e apresentado por elas através de suas dimensões humanas, "criando vínculos do ator com sua vida interior, com seus colegas e com o público”. (BROOK, 2005, p. 26) E esses vínculos, essas redes devem ser tecidos no momento presente da apresentação. $\mathrm{O}$ ator, como parte de um todo espetacular, é um ator comum, um ser qualquer que está em relação, em harmonia, em alegria com outros homens quaisquer.

Cremos que a relação teatral é formada por afetos lançados em múltiplas direções. Todos os corpos são ativos (agem) e passivos (acolhem), capazes de afetar e serem afetados. O ator como qualquer um está inserido no meio que o atravessa e, por sua vez, o meio também é atravessado por ele. Ou seja, acontece troca, interação e comunhão entre corpos e espaços, produzindo bens imateriais.

$\mathrm{O}$ ator cria junto com o expectador, que por sua vez cria junto com o ator. Esse ato, essa operação é um processo que resulta na própria criação. Desta maneira, entendemos o teatro como experiência, como movimento. Ele cria e se recria o tempo todo. No ponto de vista da atuação, cada ação do ator vibra no espaço gerando percepções no público. Essas percepções se transformam em ações, na medida, que retornam para o ator, que as percebe e as transforma novamente. E tudo acontece há todo momento, no ínfimo presente da experiência.

Nesse sentido, compreendemos que "atravessar" é uma ação e, também, uma percepção baseada na relação. Nestes termos, ator e público agem, percebendo; e percebem, agindo, baseados no momento do encontro ou, ainda, através das suas possibilidades de encontros, contaminando e possibilitando uma nova organização social.

Assim, se consideramos que o atravessamento é a intenção do ator: ele deve colocar sua atenção (a flecha) e sua intenção (atravessar) alinhadas à ação (atirar). Entretanto, como propôs Ferracini, esse alinhamento

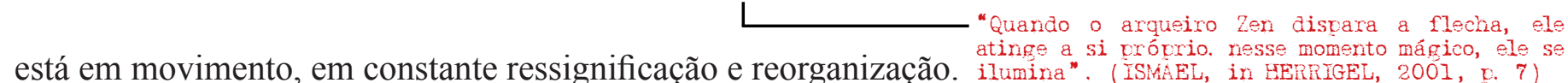
Como esclarece Adriana de Mariz, antropóloga e atriz, “o ator (...) pode ser visto como um 
construtor de pontes entre humanidades. (...) A matéria com a qual edifica essas pontes é o próprio corpo. É por seu intermédio que ele tem acesso a outras subjetividades, a outras formas de ver e sentir o mundo. O ator constrói, com seu corpo, com sua voz, outras humanidades em si mesmo”. (2007, p. 10). E é necessário praticar e criar esses corpos, essas singularidades. Cabe ao ator, através de suas vivências, compor, decompor, selecionar, aumentar ou diminuir sua potência múltipla de agir-perceber.

Se, tal como Brook, consideramos que a criação se dá inseparável do público (1994, p. 25), na preparação, que antecede o encontro, os bens imateriais são os próprios processos de aprendizagem do ator, que possibilitam sua movimentação em espaço vibrátil, relacional, fusional na apresentação, no ato criador em si.

Para guiar a produção de bens imateriais durante a preparação do ator, adotei, então, a prática do Body Mind Centering ${ }^{\circledR}$ como procedimento metodológico. Pois, como descrito anteriormente, ele é baseado em princípios empíricos, na experiência de quem o pratica e o estuda. Considera e reconhece o próprio processo de percepção e ação global do indivíduo, alinhando atenção, intenção e ação.

Para Cohen, B. B., "Sentir não é somente ser estimulado passivamente; perceber não é apenas receber estímulo; motricidade não é só responder diretamente ao estímulo. Há atividade perceptual tanto na atividade motora e quanto há atividade motora para receber estímulo, na percepção”. (2008, p. 118)

Se, como Brook, percebemos que no teatro existe apenas uma etapa: o evento em si; e que ele é dividido em duas fases: preparação e nascimento (1994, p. 24), o foco dessa pesquisa está na preparação do ator, englobando seu trabalho sobre si mesmo e sobre a personagem. Ou seja, amalgamamos o estudo da educação dos movimentos e a preparação de uma personagem. Tentamos criar ações baseadas nas percepções, abrindo espaço para a continuidade do jogo "percepção-ação" com o público.

De acordo com Burnier, “a arte trabalha antes de mais nada com a percepção. (...) Quando atinge a percepção, é que ela revoluciona. É no inconsciente que encontramos nossa particularidade, nossa individualidade, mas também os elos que nos atam uns com os outros. E a arte, quando logra atingir nosso inconsciente, nossa percepção profunda, vasculha um universo equiparável ao dos sonhos, dos pesadelos, como desejou Artaud”. (BURNIER, in FERRACINI, 2006 b, p. 25) 
A relação entre consciência e inconsciência inerente ao método, permite que o ator sinta, emocione e aja em fluxo, entendendo seu aprendizado como devir e relação. Desta forma, suas experiências em sala de trabalho são dependentes do jogo entre percepção e ação. Elas podem ser iniciadas por diferentes partes, conjuntos ou sistemas corporais; lembrando que cada sistema possui seu próprio pensamento e padrão de expressividade dentro de individualidades e culturas.

Portanto, percebemos que, ao (des)organizar o alinhamento entre a atenção, intenção e ação do intérprete, a prática do método $\mathrm{BMC}{ }^{\circledR}$ potencializa e dinamiza o ator para o encontro, pois é na percepção da presença e ação celular que o ator pode criar, modificar e expandir a produção de bens imateriais.

Para Ferracini, “a poesia do trabalho do ator, sua célula criativa, não é, dessa forma, a ação física codificada em sala de trabalho, no momento pré-expressivo de treinamento, mas, sim, essa ação física codificada como possibilidade de recriação dela mesma no momento da atuação. A poesia do ator está no momento do Estado Cênico e não no trabalho pré-expressivo”. (2006 a, p. 150)

Desta maneira, o desafio desse projeto foi utilizar esse material perceptivo para a elaboração cênica. Busquei ações baseadas nas percepções, visando uma apresentação final em que este procedimento fosse (in) visível.

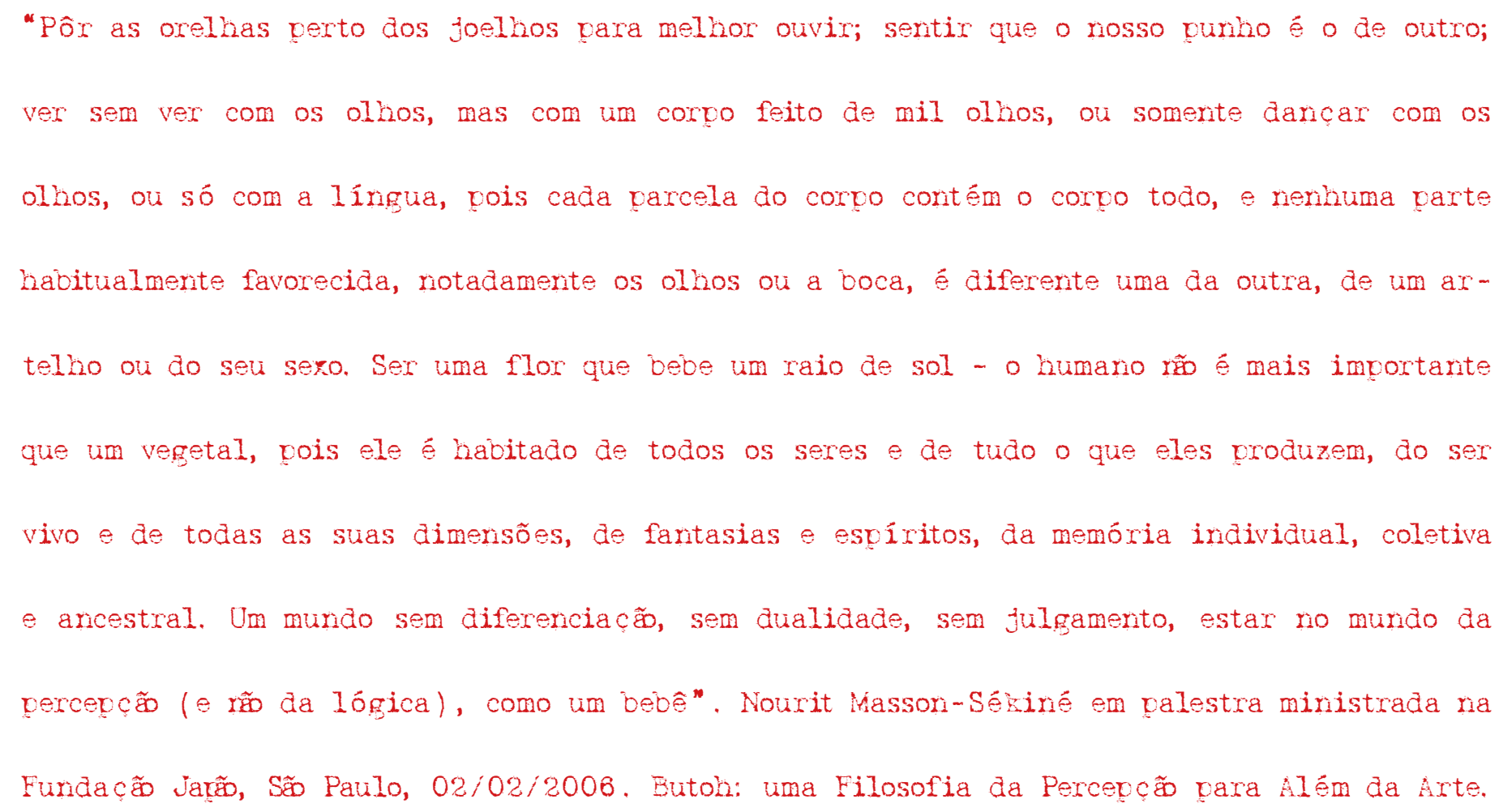




\subsection{OS GUIAS}

A preparação foi guiada, principalmente, por pensamentos da prática $\mathrm{BMC}\left({ }^{\circledR}\right.$ (princípios para corporificação); dos atores-pesquisadores do Lume (estudos e reflexões sobre o ofício do ator); do diretor, performer e teórico Renato Cohen (princípios da performance); do agrônomo e ecólogo Evaristo Eduardo de Miranda (estudos de teologia sobre o simbolismo do corpo humano); do professor e orientador Armando Sérgio da Silva (pedagogia do intérprete); da escritora Clarice Lispector (o universo ficcional); e dos testemunhos e acompanhamentos contínuos do CEPECA - Centro de Pesquisa em Experimentação Cênica do Ator. Cabe, aqui, fazer um breve descrição sobre alguns desses suportes com a finalidade de facilitar e preparar a leitura sobre o processo.

O processo de corporificação, já mapeado, possui princípios para a exploração dentro de cada sistema. Percorri, nessa preparação, os sistemas ósseo, orgânico, muscular e endócrino, e padrões neurológicos básicos. Seus princípios e pensamentos serão detalhados durante a descrição do processo, pois eles se confundem com esse.

Encontrei ressonância nos relatos e pensamentos sobre o trabalho do ator nas vozes de atores-pesquisadores do Lume Teatro (Núcleo Interdisciplinar de Pesquisas Teatrais da Unicamp). Fui guiada, principalmente, por Renato Ferracini que desenvolve pesquisas práticas em codificação, sistematização e teatralização de técnicas corpóreas e vocais não-interpretativas para o ator. Através de suas tentativas de conceituar a criação em arte, recorri aos conceitos de corpo-subjétil, punctum e matriz.

Nas palavras de Ferracini, “(...) como ator, prefiro realizar um outro exercício discursivo: não subdividir corpos tentando encontrar regras especificas de cada universo corpóreo criado para depois pensar um relacionamento entre eles até chegar ao corpo-em-arte. Prefiro, sim, pensar um único corpo, aberto a todas as multiplicidades inerentes a ele mesmo e que se autogera nele mesmo, incluindo aí, o corpo cotidiano, o corpo-em-arte, as ações físicas e vocais geradas nesse corpo-em-arte e mesmo a zona de relação com o espectador e com o outro ator, essa zona de afetar e ser afetado, essa zona de turbulência. Essse corpo uno em multiplicidades, que engloba todos os outros corpos, ações, comportamentos e zonas possíveis é que estou 
dando o nome, aqui, de corpo-subjétil. (...) O corpo-subjétil é uma espécie de vetorização e transbordamento do corpo cotidiano em direção ao uso artístico desse mesmo corpo”. (2006 a, p. 90 e 91)

Dessa forma subjétil abordei o corpo, sem negar ou afirmar sobre um corpo cotidiano ou extracotidiano, mas considerando-o corpo único, aberto, permeável e poroso. Se pensar junto com Ferracini sobre a multiplicidade no uno, percebo que o corpo subjétil é considerado uma potência espetacular em si, pois transborda de si - está em relação, é atravessado e atravessa. Em consonância com meus pensamentos anteriores, ele é formado por singularidades heterogênias.

Visto que o corpo-subjétil é inserido numa zona de jogo e criação junto ao espectador, sua criação em sala de trabalho está na percepção das portas de entrada de estados corporais, e não na codificação das ações em si. Os punctums são essas portas. E as matrizes são corpos varridos por punctums. Durante a descrição do processo, pode-se observar a preparação consciente e inconsciente de punctums e matrizes ósseas, orgânicas, musculares e endócrinas.

Como citei anteriormente, nesse processo uni a preparação do ator sobre si mesmo e seu trabalho sobre a personagem. Pois considerei, tal como Brook, a existência de duas fases (preparação e nascimento) de uma única etapa, o evento teatral. Então não diferenciei os trabalhos, algumas vezes distintos, do ator. Adotei a atitude de "desestruturar e desestabilizar a estrutura elou desestrutura - função do ator enquanto trabalho pré-expressivo na construção de seu corpo-subjétil, (FERRACINI, 2006 b, p.19) no próprio processo de preparação da personagem.

Encontrei nos pensamentos de Renato Cohen sobre a preparação do ator-performer, pistas para localizar o olhar sobre esse trabalho:

“No processo de criação "ator-performer”, quando existir um trabalho de personagem, este vai ser muito peculiar (...). O processo vai se caracterizar muito mais por uma extrojeção (tirar coisas, figuras suas) que por uma introjeção (receber a personagem). (...), mas na performance art esse processo é mais radical, sendo realçado pela própria liberdade temática que se faz com que se organizem roteiros a partir do próprio ego (self-as-context). O performer vai representar partes de si mesmo e de sua visão de mundo. (1989, p.104) 
Não quero, contudo, traçar e apontar diferenças entre o que seria um trabalho do ator-intérprete e o do performer, pois suas fronteiras estão cada vez mais diluídas e essa diferenciação não faria sentido. Como o próprio Renato Cohen mostra,

“É esse o processo dialético de absorção da performance. Em termos de técnicas de criação e atuação se absorveu um pouco de tudo: as técnicas de interiorização propostas por Stanislavski-principalmente através da "releitura" deste feita por Meyerhold e Grotowski (...) - de Grotowski veio também todo o trabalho de laboratório (de “extrojeção”, e não no sentido usual do termo que é de pesquisa contexto da personagem); o teatro didático-conceitual guarda muita semelhança-toda essa dialética atuar-interpretar, tempo ficcional X tempo real, está muito próxima do conceito brechtiano de distanciamento (o Verfremdungseffekt); o teatro ritual proposto por Artaud (a ruptura com a representação, o uso do irracional-metafórico, o discurso da mise en scène não cativo à palavra); o teatro oriental com toda sua movimentação num estado de "alfa", o teatro de intervenção e escândalo, herdeiro das manifestações dadá e surrealistas, a plasticidade e o uso do atuante como elemento sígnico (a partir da incursão dos artistas plásticos na mídia teatro), o instant-acting e o teatro espontâneo que vem do happening e se aproxima do psicodrama formulado por Moreno, fora a absorção de outras linguagens como a dança, o circo, a mágica, etc”. (1989, p. 108).

Ao ler as palavras como mapas para a exploração, entendi essa preparação, como sendo um processo performático por sua propriedade de absorção e hibridicidade, visando o desenvolvimento das habilidades psicofísicas pessoais do ator e seus desdobramentos estéticos.

Da mesma forma que não distingui os corpos (cotidiano e extracotidiano), não pensei em pré-expressividade e treinamento. Vi que a personagem é um emaranhado sintético dos estados provenientes dos jogos de percepção-ação do aprendizado do ator, sendo uma resultante estética dessa dinâmica. Também pude considerá-la guia para a experiência em sala de ensaio e para o momento do encontro com o público. Logo, a preparação da personagem se confundiu com a preparação do ator, que representa partes de si mesmo e de sua visão de mundo.

Contudo, posso considerar, ainda, as partes de si mesmo como outros eus, outras humanidades. Assim, a personagem é um conjunto de eus, de outros que me prepara para o encontro. 
Nesse sentido, recorri aos símbolos corporais judaico-cristãos como suporte para, justamente, trabalhar a relação entre eu (minha visão de mundo) e um outro (outras subjetividades em mim). No livro "Corpo: Território do Sagrado", Evaristo Eduardo de Miranda entende o corpo em sua evolução escatológica e ontológica, unindo o cotidiano dos homens às suas dimensões sagradas. Ao penetrar na simbologia corporal do universo bíblico, proposta pelo autor, encontrei guias semânticos, etimológicos, culturais, psicológicos e espirituais. Através deles, pude explorar a geografia corporal individual em comunhão com o sagrado, aqui, entendido como a experiência nas subjetividades heterogênias do uno, do corpo-subjétil.

Nesta obra, o teólogo nos conduz pelo caminho da Árvore das vidas, o corpo sagrado, onde cada parte ou órgão é alicerçada pela tradição mística judaica. Percorremos verticalmente, de baixo para cima, dos pés (Malchút ou Reino) à cabeça (Ketér ou Coroa), territórios corporais mágicos, que carregam em si os mistérios do homem em comunhão com o divino.

Para o autor, “cada palavra, termo ou conceito corporal, deve ser escutado e não abandonado. Como escreve Mainônides, 'em cada palavra existe um duplo significado, o literal e o figurado. O primeiro é tão valioso quanto a prata, contudo mais precioso é o significado oculto; de modo que a significação figurada está, com relação à literal, na mesma relação do ouro com a prata. Assim também, tomadas as figuras dos profetas ao pé da letra, encerram certa sabedoria útil para muitas finalidades, entre outras, o melhoramento da sociedade humana, como os Provérbios de Salomão, por exemplo. Entretanto, seu sentido oculto é profundíssima sabedoria que leva a descobrir a verdade'. Cada conceito ou nome na geografia do corpo, cada palavra, tem algo a nos dar, um alimento sutil. É preciso achá-lo, dançá-lo e degustá-lo. Seu sabor é sabedoria”. (MIRANDA, 2000, p. 23)

Desta maneira, Miranda apresenta o esquema corporal através do esquema da Ávore das vidas ou Árvore das sefirot. Ele estrutura as principais partes do corpo humano em matrizes, a saber:

- $\quad$ O Reino (Malchút) - pés, pernas, joelhos e coxas;

- A Porta do Homens - plexo urogenital;

- $\quad$ A Matriz Abdominal - útero, umbigo, rins, estômago, pâncreas, fígado;

- $\quad$ A Matriz Peitoral - coração, pulmão, coluna vertebral, mãos, ombros, clavículas; 
- $\quad$ A Porta dos Deuses - pescoço;

- $\quad$ A Coroa (Ketér) - cabeça, ouvidos, boca, dentes, língua e saliva, nariz, olhos, crânio;

Para esclarecer e ilustrar brevemente o simbolismo, aqui emprestado, recorro às próprias palavras do autor, "a maioria das representações da árvore das sefirot pode ser correlacionada, ponto por ponto, com um corpo humano. Existe uma analogia fundamental entre as dez sefirot e as partes essenciais do corpo. Seu (Binah Hokhmah) desenho na tradição judeu-cristã revela um duplo traçado: o traço da vontade divina de criar o Homem 'na imagem de Deus'e o traço último, o de fazê-lo à sua semelhança'. Sem aprofundar as complexas concepções da visão cabalística do humano, podem-se indicar alguns elementos essenciais dessa relação Árvore-Corpo, Gevurah Hesed

evitando qualquer antropomorfização da divindade. O Reino (Malchút) corresponde aos pés e à base do corpo humano. A Vitória (Nétsach) e a Glória (Hod) énquadram suas pernas e o Fundamento (Iessód) corresponde ao órgão genital. Esse triângulo enquadra o plexo urogenital, a Porta ou Passagem dos homens e a matriz abdominal. A Beleza (Tiféret) centrada no coração, no plexo cardiorrespiratório, é o vértice inferior de um triângulo que enquadra a matriz peitoral e cujos outros dois vértices Justiça (Guevurá) e Misericórdia (Chessed) apontam para as mãos e sustentam os braços, como Graça e Força. Inteligência (Biná) e Sabedoria (Chochmá) repousam sobre os ombros, de cada lado da cabeça, tendo ao centro o pescoço, a Porta ou Passagem dos deuses para a cabeça, para a Coroa (Ketér). A ascenção pela árvore corporal, do TER para o SER e deste para o DEVENIR é um caminho iniciático e terapêutico. Uma via de superação das dualidades e antinomias, rumo à unidade, ao Iud do tetagrama espada, ao coroamento.” (2000, p. 51)

Entretanto, não se pode ler esses caminhos de forma hierárquica, pois não são percorridos como degraus de uma escada. É uma exploração e uma jornada que visa viver-corpo. A árvore representa “ $a$ vida em perpétua evolução e em ascenção rumo aos céus. A árvore evoca a comunicação entre, de um lado, as realidades cósmicas, subterrâneas e terrestres e, de outro, as celestes ou aéreas. A árvore é um símbolo do caminho ascensional entre o visível e o invisível, um lugar das manifestações do divino. ” (2000, p. 37)

Durante o processo, cruzei as abordagens sistêmicas do BMC® com os simbolismos de cada parte, com o intuito de expandir minhas possibilidades criativas. Pois acreditei que, dessa forma, as esferas da identidade (eu), alteridade (outros eus) e divindade (encontro) poderiam se tornar espirais imbricadas. Onde 
guardariam em seus pontos de contato, punctums e matrizes do corpo-subjétil. Cada matriz possui seu próprio pensamento, e, algumas serão mais detalhadas no decorrer da leitura, juntamente com a prática empregada.

A coragem para assumir uma prática pessoal e considerá-la passível de exploração e pesquisa científica, deu-se, em grande parte, pela pedagogia defendida pelo prof. Dr. Armando Sérgio da Silva, orientador desse processo. Em sua tese de livre docência, "Oficina da Essência", o professor estimula e valoriza a apropriação particular de cada intérprete aos estímulos apresentados. Ele utiliza, entre outros, as sensações e percepções como instrumento para aproximação entre texto e fisicalidade, propiciando ao ator sua impressão digital, gerando potencialidades expressivas.

Para Silva, “a personagem, (...) para o ator não passa de um estímulo, de uma provocação para sua arte. Da mesma maneira que algum estímulo serviu anteriormente para o dramaturgo imaginar a personagem nas situações dramáticas que descreveu. O ator, estimulado por essas indicações, vai usar o seu próprio corpo para tornar concreto e sensivel o estímulo inicial. Se existe claramente um estímulo a ser realizado, por outro lado, as variantes de opções de concretização são tantas quantas pessoas tetarem realizá-lo. Ou seja, cada ator realizará sempre e necessariamente uma concretização pessoal e, portanto única”. ( 2003, p. 28 e 29)

Sendo assim, o professor nos impulsiona a descobrir o quê representar. Qual a personagem ou estímulo inicial? E, depois de definido, como desvendá-lo? como corporificá-lo? como transformá-lo em signo e expressá-lo?

Essas perguntas foram guias para todo o grupo de pesquisa orientado pelo professor, o CEPECA - Centro de Pesquisa e Experimentação Cênica do Ator, sediado no Departamento de Artes Cênicas da Escola de Comunicação e Artes/USP. Esse Centro de Pesquisa reúne, em grupo de estudos práticos sobre interpretação, professores, alunos de pós-graduação e de graduação. Metodologicamente, projeta-se a realização de um roteiro de trabalho que compreende a aplicação de ações, procedimentos e exercícios, decorrentes de projetos de pesquisa desenvolvidos por cada componente, visando resultados perceptíveis em trabalhos práticos e espetaculares.

As pesquisas devem levar em conta as necessidades dos atores na composição do desempenho teatral 
bem como da criação cênica autoral. Neste sentido, caminham juntos os aspectos acadêmicos e criativos, ou seja, professor e alunos se obrigam e se comprometem com os resultados estéticos, a partir de suas escolhas metodológicas.

Desde 2007, o CEPECA abriga, por exemplo, estudos sobre a utilização de princípios do Aikido; do Ioga e do Tai-chi-chuan; da Memorização pela Escrita; da Mímica Corporal Dramática, entre outros, no trabalho do ator. O Centro possui uma rotina de encontros semanais onde os atores-pesquisadores mostram e comentam resultados práticos e teóricos parciais. Consequentemente, os pesquisadores do CEPECA acompanharam e auxiliaram o andamento da presente pesquisa, a partir do olhar especialista, rigoroso e incentivador.

Assim, todos nós devíamos responder à primeira pergunta: o quê representar? Para isso, escolhemos, inicialmente, o texto Hamlet, de Shakespeare, como estímulo. Entretanto, nossa tarefa era selecionar uma cena, uma personagem ou uma situação para, depois, transformá-la e recriá-la contemporaneamente.

Depois de feitas as escolhas, fomos guiados pelo professor por algumas ações, desta forma definidas:

- “ “A Definição dos Estímulos Dramáticos', ou 'O Desvendar do Objeto', em que o ator procura contatos físicos com as estruturas dramáticas vividas pela personagem, o prazer físico que os impulsos dramáticos Ihe sugerem. (...) Os procedimentos desta primeira ação, portanto, devem estimular no ator o desejo, senão para experimentar, para 'explicitar'o seu prazer físico. O intuito é fazer com que ele chegue àquele estado de ‘(...) excitabilidade que constitui o agir do ator’”. (SILVA, 2003, p. 32 e 33)

- “(...) os procedimentos para a consecução desta ação, são organizados de maneira a definir, para as microcenas, estímulos sensoriais a que estariam sujeitas as personagens e improvisar, com anteparos e depois incorporando os referidos estímulos, visando reações espontâneas dos atores, as 'Potencialidades Expressivas'”. (SILVA, 2003, p. 51)

- $\quad$ “A 'Ação' chamada de 'Composição de Signos' parte (...) da verdade corporal. (...) Os atores devem observar atentamente seus exercícios filmados e fotografados e, escolher, sozinhos e depois em conjunto tais 'Potencialidades Expressivas'. O objetivo desta ação é o de transformar essas 'Potencialidades' em linguagem expressiva, em signos articulados”. (SILVA, 2003, p. 59) 
Através dessas ações contaminadas por meus guias conceituais, simbólicos e ficcionais, percorri e

0 conto Amor, de Clarice Lisvector, que será
descrito a sequir, funto com o wrocesso.

relatei as potencialidades de desvendamento, expressividade e composição do nosso foco de estudo, o método BMC® aplicado à preparação do ator.

\subsection{OS PARCEIROS}

Como pode-se observar, a experiência científica e artística nunca acontecem, apenas, individualmente. Elas se originam, desenvolvem e concluem a partir, com e para o outro. Esse outro pode se concretizar em pensadorores ou teóricos; mestres; técnicas; amigos; colegas de trabalho; palavras pixadas, faladas, gritadas na rua, no bar ou em casa; alunos; enfim, o pesquisador e a pesquisa sempre estão em relação e troca.

Portanto, as experiências subjacentes com os atores da Zero Zero Cia de Teatro e com a prática do $\mathrm{BMC}{ }^{\circledR}$ através de Adriana Almeida Pees deram o impulso inicial à pesquisa. A ele, uniram-se os escritos e práticas de Bonnie Bainbridge Cohen, Linda Hartley, Renato Ferracini, Renato Cohen, Evaristo Eduardo de Miranda e Clarice Lispector. Além, da constante vigília e encorajamento do Prof. Dr. Armando Sérgio da Silva e dos membros do CEPECA.

Contei, ainda, com a colaboração e especial dedicação do Teatro de Senhoritas: Isis Madi e Sandra Pestana que, em conjunto, criaram a peça "Ana-me", resultante espetacular do processo. E com a vontade e empenho de alunos-atores que generosamente se colocaram em experiência junto comigo. 
2. A PREPARAÇÃO

"No teatro, doravante poesia e ciência devem identificar-se. (...) Saber antecipadamente que pontos do corpo é preciso tocar significa jogar o espectador nos transes mágicos".

(ARTAUD, 1999, p. 172) 
"Ana dava a tudo, tranquilamente, sua mõ pequena e forte, sua corrente de vida" (...) "Sua vrecauç̃ reduzia-se a tomar cuidado na hora perigosa da tarde, quando a casa estava vazia sem precisar mais dela, o sol alto, cada membro da família distribuído nas suas funções" .

"O bonde se arrastava, em seguida estacava. Até o Humaitá tinha temọ de descansar. Foi então que olhou para o homem parado no ponto. A diferença entre ele e os outros é que ele estava realmente varado. De pé, suas mãos se mantinham avançadas. Era um cego" (...) "O que chamava de crise viera afinal. E sua marca era o prazer intenso com que olhava agora as coisas, sofrendo esvantada" (...) "Um cego mascando chicles mergulhara o mundo em escura sofreguidão".

"Inquieta, olhou em torno. Os ramos se balancavam, as sombras vacilavam no chro. Um pardal ciscava a terra. E de repente, com malestar, vareceu-lhe ter caido numa emboscada. Fazia-se no Jardim um trabalho secreto do qual ela comecava a se averceber"

"Mas quando se lembrou das crianças, diante das quais se tornara culọada, ergueu-se com uma exclamaça de dor".

"O vequeno horror da poeira ligando em fios a parte inferior do fogão, onde descobriu a vequena aranha. carregando a Jarra para mudar a água - havia o horror da flor se entregando lânguida e asquerosa às suas mãos. O mesmo trabalho secreto se fazia ali na cozinha". (..) "E, se atravessara o amor e o seu inferno, venteava-se agora diante do escelho, por um instante sem nenhum mundo no coraç̃o. Antes de se deitar, como se apagase uma vela, sovrou a vequena flama do dia”. (LISPECTOR, 1998, 0.19-29) 


\section{1. O QUÊ REPRESENTAR - O ESTÍMULO}

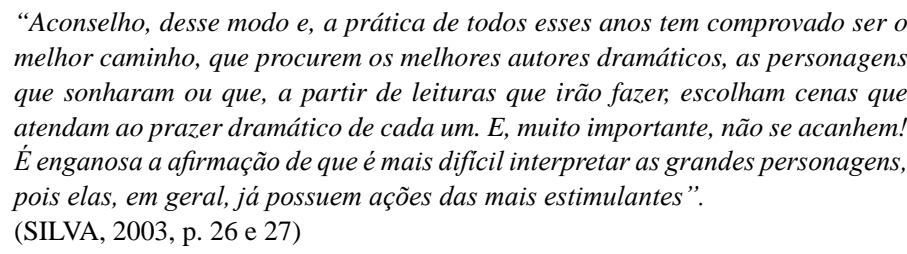

"Aconselho, desse modo e, a prática de todos esses anos tem comprovado ser o melhor caminho, que procurem os melhores autores dramáticos, as personagens que sonharam ou que, a partir de leituras que irão fazer, escolham cenas que atendam ao prazer dramático de cada um. E, muito importante, não se acanhem! É enganosa a afirmação de que é mais difícil interpretar as grandes personagens, pois elas, em geral, já possuem ações das mais estimulantes". (SILVA, 2003, p. 26 e 27)

Como antecipei, iniciei o processo dessa pesquisa no CEPECA, através da escolha do texto-estímulo, Hamlet, de Shakespeare. Deveria selecionar uma cena, personagem ou situação para, depois, transformá-la e recriá-la. Então, minha atenção pousou sobre a personagem Ofélia, despertando meu imaginário...

$\begin{array}{ccccc}\text { Água } & \text { Cachoeira } & \text { A mor } & \text { Jovialidade } & \text { Vestido } \\ \text { Canções } & \text { Loucura } & \text { Cartas } & \text { Fragilidade } & \text { Brancura } \\ \text { S Submissão } & \text { Sensualidade } & \text { Natureza } & \text { Fraqueza }\end{array}$

... e me conduzindo à Ana, protagonista do conto Amor, de Clarice Lispector, meu estímulo de representação.

O conto apresenta Ana, uma dona de casa acostumada à vida rotineira que leva, sem exigir dessa vida nada de novo, nada que a surpreenda, nada que fuja ao equilíbrio do seu dia-a-dia. No entanto, o seu sereno cotidiano é ameaçado por um momento do dia em que se encontra sozinha, sem nada que fazer, nem ninguém para cuidar. Nesses instantes, Ana vai às compras ou leva objetos da casa para o conserto.

Certo dia, no bonde, a sua paz é ameaçada por um momento de crise em que tudo à sua volta, de repente, parece-lhe estranho, assustador - de repente, ao ver um cego, mascando chicletes, ela percebe o mundo de forma diferente. E inicia um processo de reflexão e perturbação, olhando para sua própria escuridão, sua própria percepção da vida.

Atordoada por essas sensações, Ana salta do bonde, e se percebe no Jardim Botânico. Lá ela se depara com o trabalho secreto da natureza. Observa o apodrecimento da fruta, o andar da aranha sobre a árvore, o ciscar do pardal, o rumorejar das águas e percebe a decomposição, a crueza e a beleza do mundo.

A lembrança dos filhos a faz retornar para casa e preparar o jantar. Entretanto, sua rotina já está contaminada pelo cego, pelos segredos do Jardim e pelo risco de viver. Dessa forma, Ana recebe as visitas, janta, coloca os filhos para dormir, e finalmente, adormece. 


\title{
2. 2. DESVENDAMENTOS - OS ANTEPAROS
}

\begin{abstract}
"O problema é que a personagem não é um simples objeto e, nem está presente. Com efeito, podemos dizer que, para o ator, num primeiro momento, a personagem não existe, pelo menos, como um objeto sensivel e identificável. O estímulo inicial, aquilo que chama a atenção do ator, é uma espécie de dado incompleto, um quebra-cabeça, um jogo que ele pretende completar". (SILVA, 2003, p. 27 e 28)
\end{abstract}

O primeiro exercício proposto pelo professor ao CEPECA foi narrar com o máximo de detalhes a história escolhida. Para isso, roterizei o conto; separei partes; colori e o espalhei com letras grandes em folhas brancas.
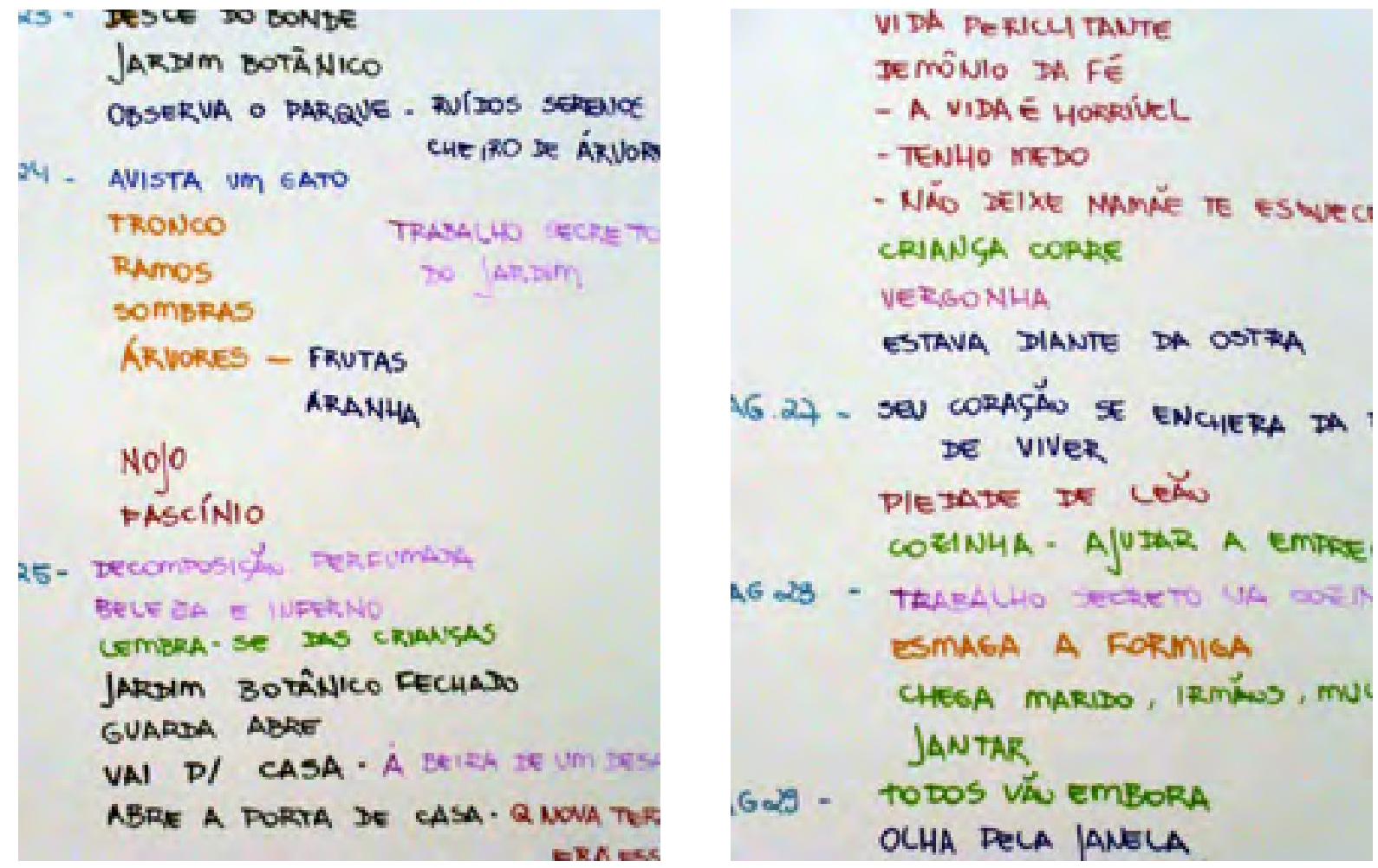

De acordo com o professor, essa fase permite que o ator se comprometa com sua criação, analisando, ao mesmo tempo, que vive prazerosamente a dramaticidade de seu estímulo. "Quanto mais se acredita na qualidade dramática dos estímulos, mais vontade de contar, mais detalhamento de narrações ativas de percepção, de sensasões que consequentemente, o que significa o início do processo de imaginação, ou seja, transformar em vida a memória das sensações”. (SILVA, 2003, p. 38)

Portanto, inerente ao ato de narrar está a atualização de memórias. Nos entrelaçamos aos estímulos, percebendo-os como impulsos físicos e iscas para memórias. A escolha das palavras e suas enunciações são exercícios de exposição. O ator já é colocado num espaço vulnerável e de risco onde suas ações o lançam 
para a experiência. Assim, provamos os sabores, as cores, os sons, os movimentos, os cheiros e as texturas das palavras selecionadas e pronunciadas.

Através desse procedimento, pude organizar a estrutura literária numa narrativa dramática, percebendo ações, tempos e espaços. Ganhei consciência dos fatos que me impulsionavam à criação, ao "prazer teatral”, por exemplo: as cenas em que a protagonista vê o cego e sua experiência no Jardim Botânico; as expressões paradoxais e o desafio de corporificá-las em cena.

"As valavras vroduzem sentido, criam realidades e, às vezes, funcionam como cotentes mecanismos de subjetivaç̃o. Eu creio no coder das valavras, na forca das palavras, creio que fazemos coisas com as calavias e, tamoem, que ds palavias fazen coisas conosco. A valavras determinam nosso vensamento porque rö pensamos com ven

Ao contar a história, percebi pontos de con- samentos, mas com oalavias, rö densamos a castis de uma sucosta Quando fazemos coisas com as valavas, do que se trata 6 de como damos sentido ao que somos e ao que nos acontece, de como corretato com as sensações da personagem (estímulo), lacionamos as valavras e as coisas, de como nomeamos o que vemos (EONDIA, 2002, D. 2I)

ou seja, lembrei de algumas ocasiões em que tive experiências corporais fortes e marcantes relacionadas a algum tipo de epifania, enjôo ou alteração. Algumas delas foram: pensar em inglês andando em volta de um lago; ficar entre a porta do banheiro e da cozinha da minha casa desesperada com as mãos no rosto sem conseguir me mover; vomitar e ficar enjoada em ônibus e carro. Intuitivamente, relacionei o estímulo "mal-estar" ao sistema digestivo, abrindo possibilidades de corporificação dessa expressão através do método BMC $®$. Logo, o mal-estar da personagem tocava meu mal-estar.

Então, para realizar este desejo (corporificar as expressões em cena), procurei corpos nas palavras do texto, ou seja, selecionei e organizei o conto nas matrizes corporais propostas em meu suporte simbólico, a Árvore das vidas. Ou, como designa a professor Silva, esquematizei meu anteparo de palavras.

Os anteparos são artifícios que servem para proteger o ator. Eles são "substitutos da ação corporal” e permitem que o ator brinque ou improvise com as próprias sensações e percepções. Como nos elucida Silva, "esta fase se resume no ato de, propositadamente, retardar a experimentação corporal, propriamente dita, através de jogos puros, mediados, escondidos, protegidos por outras linguagens, como: narrativa oral, música, artes plásticas, etc. Para a realização desses jogos o ator usa, como vimos, de seus 'analogon', ou seja, de seus pontos de contatos sensiveis, através de anteparos narrativos, musicais, visuais, etc”. (2003, p. 35)

Essa estruturação me permitiu desvendar uma possibilidade da anatomia simbólica da personagem. E escolher princípios da prática do BMC ® para a preparação. Ela será explicitada a seguir juntamente com 
os anteparos iconográficos. "Observar iconografias de todo o tion, na medida em que lembrem aseectos da cena ou da personagem, sevarar as mesmas. Tanto vodem ser escolnidos icones abstratos ou figurativos, fotos, vinturas, esculturas, ou trechos de filmes". (SILVA, 2003, 0. 40)

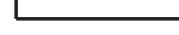

"Cada um dos atores deve ouvir, ao acaso, músicas, dos mais variados estilos, serundo seu gosto. Conforme associe trechos destas músicas com aleum momento da cena, deve selecioná-las comoor uma trilha sonora que contará a cena. A analogia oode ser com a atmosfera da cena, com o interior ou exterior da versonagem, com reminiscencias vessoais que remetam à cena". (SILVA, 2003, 0. 39)

Esses últimos, anteparos sonoros e sensíveis surgiram para, novamente, narrar a história. Entretanto,

"Para cada microcena procurar os contatos físicos com a personagem, usando para isso os cinco sentidos, as sensacões que a situaç̃ sugere/ ou estimula o ator. Assim procurar um odor, valadar, um som, uma imagem, um toque e contar detalhadamente $(\ldots) *$ ( SILVA, $2003,0.41)$

o professor mudou seu foco: deveria contar meus próprios impulsos na história. Onde a dramaticidade do conto me afetava? E como falar sobre isso, sendo permeada pelos anteparos escolhidos?

Os anteparos iconográficos selecionados foram registros ou fotos das performers Ana Mendieta e Marina Abramovic, e da fotógrafa Francesca Woodman, pois, em consonância com meu desejo, cada uma, a seu modo, experimenta seu próprio corpo-em-arte, criando com ele sua poética. As imagens foram pesquisadas em sites na internet, afim de preencher e expandir lacunas de possibilidades estéticas. Ou seja, independentemente dos conceitos abordados nas obras, elas me afetavam esteticamente, atingindo minha sensibilidade e me movendo criativamente. Seguem algumas dessas imagens e associações para ilustrar esses afetamentos:

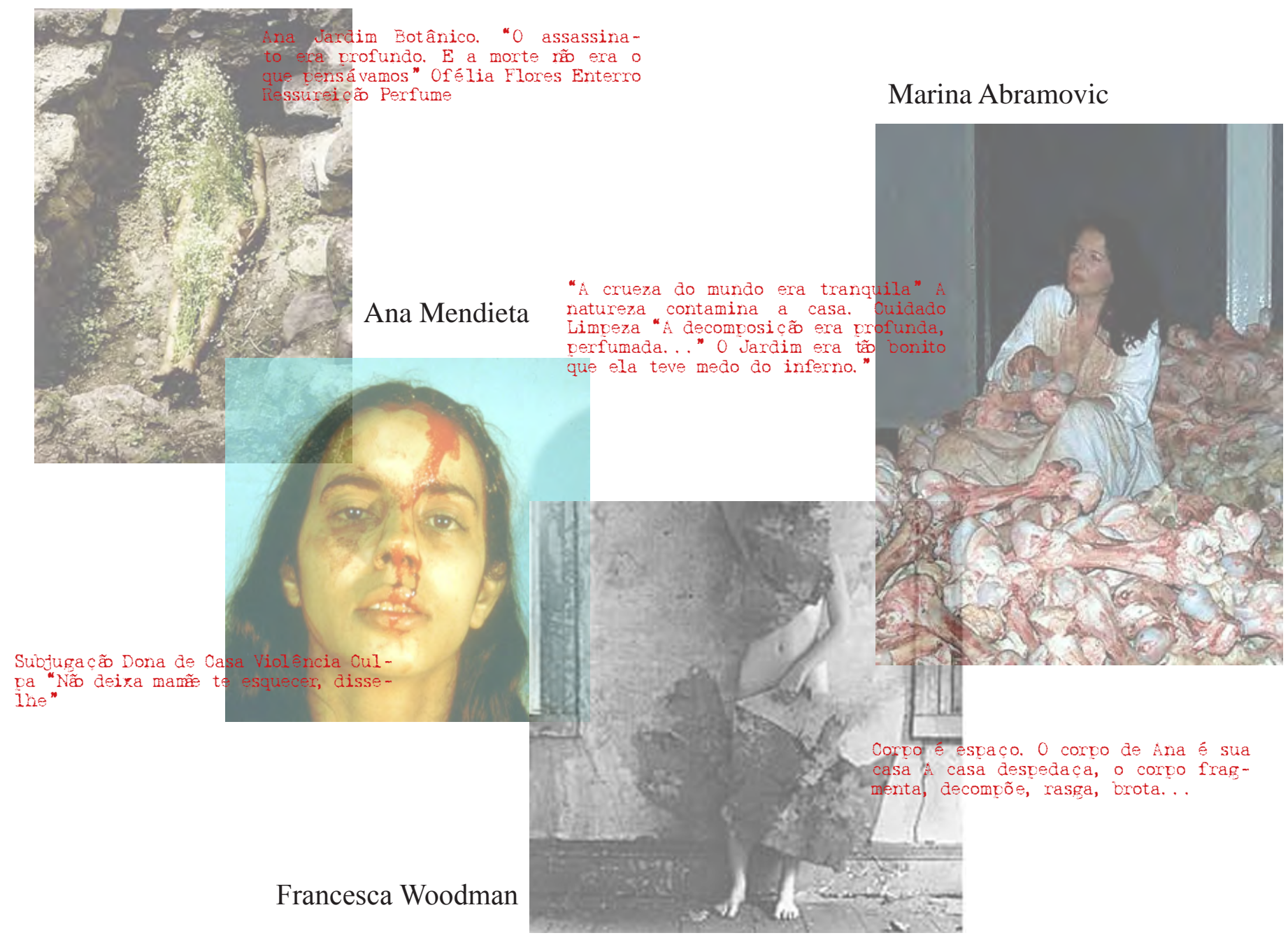


Da mesma forma, foram escolhidos os anteparos sonoros que compuseram minha próxima narrativa: $O C D$ anero contém esses antecaros e codem ser escutados durante a leitura desse trecho:

Silêncio

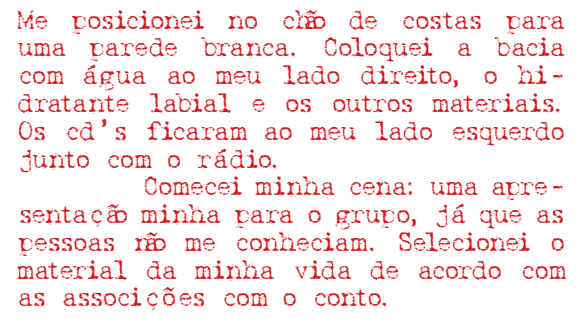

Sou meio caótica.

Não fico sem. Esse é meu vício. Hidratante Labial

fico louca com a sensação de boca

seca. Bem, amor... falarei um pou-

co sobre meus amores e a sensação

de amor que tenho do texto.

Non je ne regrette rien, Edith Piaf. É de cortar os pulsos. Romântico.

Eu sou romântica. Existem essas

histórias de amor que contam so-

bre Paris: um casal que carrega

alguma coisa, andando pela rua e,

de repente, eles abrem uma mesa,

cadeiras e um vinho. E ficam ali,

sobre a ponte, naquela paisagem

linda... Eu nunca fui a Paris... Mas

Meus olhos enchem de lágrima enquanto falo e ouco a música.

acho isso lindo...

Mãe, Tom Zé

Eu apresentava o Círculo de Giz Imagens de jornal sobre o seques-

Caucasiano, na época, e fiquei su- tro na escola russa, em Beslan.

per afetada pelo acontecimento. No

outro dia participei de um evento:

o treinamento pré-expressivo do

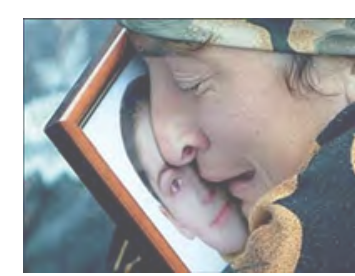


do ator em tempos de terrorismo.

Lá eu assisti um espetáculo de

dança improvisacional. Mas en-

quanto a improvisação acontecia

(ou não!), comecei a chorar por-

que aquilo não me parecia real.

Enquanto as pessoas morrem, nós

brincamos de fazer teatro... E é

isso que me motiva a fazer teatro e

o mestrado... vaḉcé falar sobre as próturias moti-

parece ingênio e embaracoso tê-las. .

Um espetáculo que me permitiu Programa do espetáculo "Sopro",

uma experiência corporal durante de Carlos Simioni e Tadashi Endo

a apresentação. Foi mágico!

Bom dia tristeza, Maria Bethânia

Lembro de muitas histórias rela-

cionadas a amigos com essa mú-

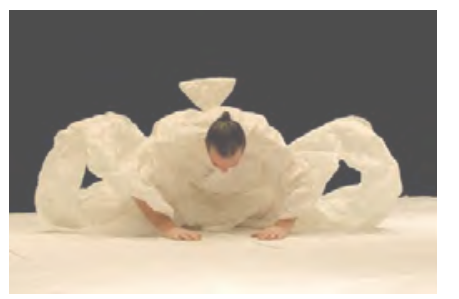

sica.

Para acabar com o julgamento de Outra coisa que me influencia mui-

Deus, Antonin Artaud

to é Artaud. Meu primeiro namora

do me apresentou Artaud quando

tinha 16 anos.

Tive um namorado depois do ou-

tro. Namorei um por cinco anos,

depois outro por dois anos, me se-

parei porque estava cansada de na-

morar. Foi ótimo. Descobri muitas

coisas a respeito de mim mesma, 
do meu corpo, o que gostava, enfim... e depois de certo tempo, quando fiquei mais calma, conheci um moço que era do Rio de Janeiro e morava em Londres. Foi super gostoso. Ele trabalhou no Festival de Edimburgo e me enviou um programa. Na época, eu não dei a mínima. Achei meio nada a ver. Depois de anos, estava remexendo na minha caixa de lembranças Em algum momento yausei a música, pois estava atordoada com as vozes. .

e reencontrei esse programa. Per-

cebi que ele estava com páginas grudadas e que tinha alguma coisa dentro. Era um CD com a voz de Artaud narrando "Para acabar com o Julgamento de Deus". Enfim, depois comecei namorar outro que Mas resse momento da escrita, esse namoro estou junto a quase dois anos...

Bem, não consigo ver o amor sem Programa da exposição de Arte o erotismo. Erótica do Centro Cultural Banco do Brasil, São Paulo.

Scene: lake in moonlight, minho. .

Tchaikovski. Ballet "O Lago dos

Cisnes”

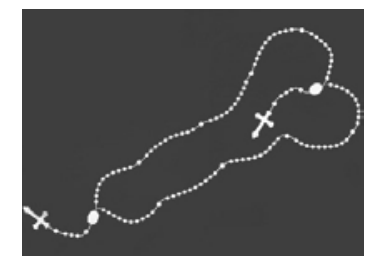


Cherry Blossom Girl, Air

Faking the Books, Lali Puna

George Aperghis Sufocamento.

Essas músicas me fazem lembrar Imgens de Ana Mendieta, Francesdo Pedro...

ca Woodman e Marina Abramo-

vic.

A bacia com água é apenas pela Bacia com água.

força do elemento.

No final, eu Já estava cansada por ter vassado por tantas histórias e exposiç̃o...

Esse exercício me deixou a vontade para encontrar o conto em mim. Alguns aspectos ficaram evidentes segundo os ouvintes (membros do CEPECA que presenciaram essa microcena), como: a contagem do tempo através dos namoros ou amores; o jogo entre realidade e ficção (pois não sabiam o que eram fatos vividos e histórias inventadas para "seduzir" o público); a autoafirmação do artista; passionalidade; intimidade e cumplicidade com a platéia.

Entretanto, essas características não foram pensadas a priori. Enquanto contava, não tinha a intenção de ser verdadeira ou falsa ou autoafirmar-me ou emocionar-me. Tudo aconteceu na relação com os anteparos E, acredito, que esse autodesvendamento incontrol ável continua acontecendo durante
a escrita (ou leitura!) desse trabalho. .

e com o público. Assim, através do encontro com a personagem, eu mesma fui evidenciada sem meu controle, pois, contraditoriamente, sentia-me protegida pelos anteparos.

Portanto, nesse momento da preparação (onde ela é a fase que precede o nascimento ou a apresentação), a personagem se tornou um canal de acesso a outros eus em mim, com o poder de deslocar minhas interpretações e subjetivações, ao mesmo tempo que as afirmava.

Então, como nos guiou o professor Silva, “depois de estabelecida a pré-partitura de estímulos teatrais - as microcenas - torna-se necessário a experimentação corporal, ou seja, a ssimilação dos estímulos pelo corpo. É pessoal e intransferivel." (2000, p. 43)

Mas, antes de prosseguir, retornemos ao anteparo de palavras formulado, pois através dele extraímos os princípios do $\mathrm{BMC}{ }^{\circledR}$ para a próxima fase: a Impressão Digital. 


\section{O REINO}

PÉS

sob os pés a terra estava fofa

esmagou com o pé a formiga

pisaria numa das crianças

\section{PERNAS}

desceu do bonde com as pernas débeis

andava pesadamente

sentou-se no banco

estremecia nos primeiros passos de um mundo fais-

cante

ergueu-se com uma exclamação de dor

avançou pelo atalho escuro

quase corria

correu com a rede até o elevador

o menino se aproximou correndo era um ser de per-

nas compridas

corria (o filho)

escapou e correu até a porta do quarto

deixou-se cair numa cadeira

levantou-se e foi para a cozinha

andava de um lado para outro na cozinha

correndo para a cozinha
"Malchút é o grande reciviente, a Esvosa do Amor divino Esse amor de Deus rara o tomem, emanado das esferas caminho sreoiso Por isso Vetér é chamado também de Rei e Malchút de Rainha. Um rouco como na história da Bela Adormecida, nós somos a fioresta, castelo a rrincesa. Mas onde está o oríncioe? Ele desce ao encontro da amada. Mas o amor do Homem vara Deus oermite o caminho inverso, ascendente, em direcã ao Princívio, vara avreender o inavreensivel, o ilimitado, a Essência, o Ein Sof. E nesse sentido ascendente, da verticalizaç̃ que o corco humano

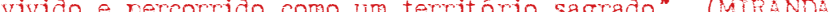
2000, v. 41)

"Objeto de tantos mitos, os dés sẽo o lugar de contato entre - homem e a terra, conto de vartida vara sua verticalizacã elevac⿱o e ascencế. Os ves revresentam a forca da alma, sucorte da costura ereta, a base de nossa estatura, o dominio do nEn (. ciência do ser. O homem rố foi chamado vara viver curvado, escreviza do, mas de vé, instaurado em sua verticalidade". (2000, c. 61$)$

"Nascendo no germe dos vés e elevando-se até os joelhos,

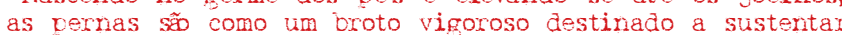
o conjunto da árvore. No vrimeiro estágio corvoral, o estágiodo TER, as vernas revresenta, toda a forca da germinaço, da ascencáo do humano $\Theta$ sua cavacidade de caminas estabelecer relacóes velas terras interiores e exteriores de seu ser". (2000, 0. 73

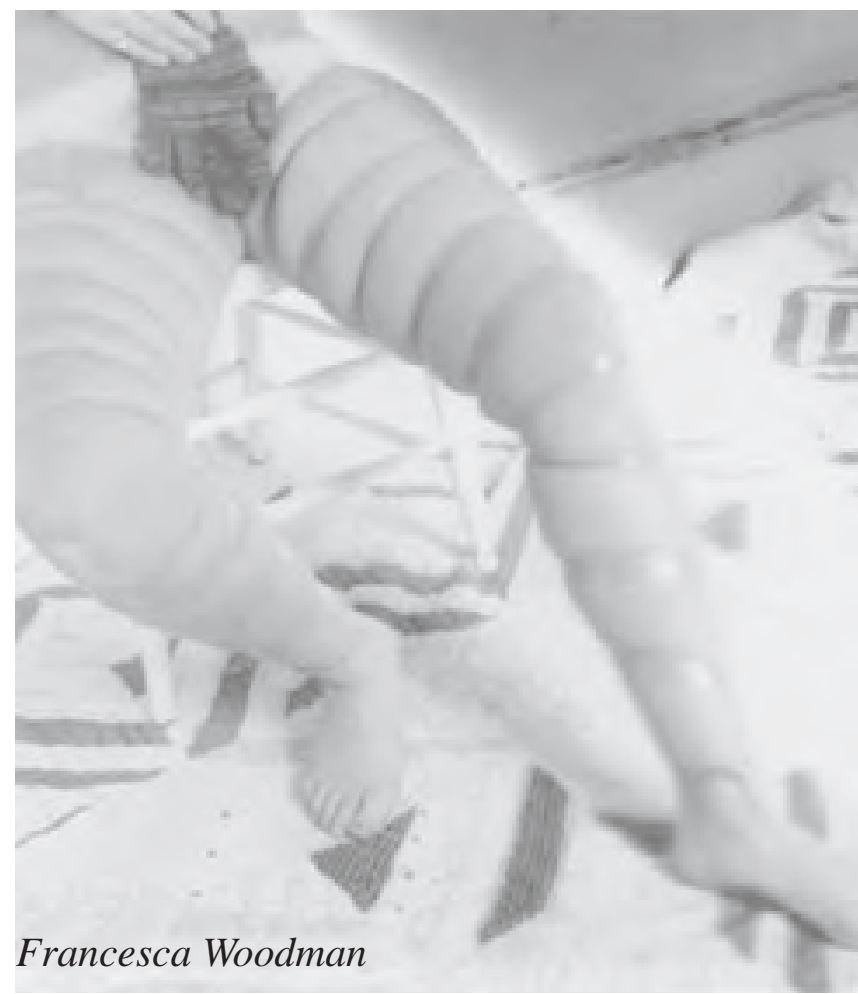




\section{A PORTA DOS HOMENS}

\section{PLEXO UROGENITAL}

o homem com quem casara era um homem verdadeiro, os filhos que tivera eram filhos verdadeiros.

"A Arvore das vidas encontra, no olero urogenital, as primeiras aberturas e comunicacões físicas cermanentes entre - interior e o exterior do humano, entre o ler $\ominus$ o SER, a maravilhosa seiva da energia erótica sobe velo tronco da

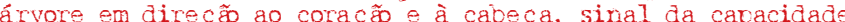
humana, à imagem do seu criador, de ser fértil. O humano o troncoliza o lero urogenital e a capacidade de revroduç̃̂́ (Í́ssod)". (2000, 0.97)

\section{A MATRIZ ABDOMINAL}

\section{ESTÔMAGO}

e de repente, com mal-estar, pareceu-lhe ter caído numa emboscada.
"Poesia é alimento. Boa música é alimento. Amar é iguaria oor ercelência. 0 amar, ser amado e deirar-se amar, recresenta o verdadeiro ágave. O estômago deveria ser recevtá-

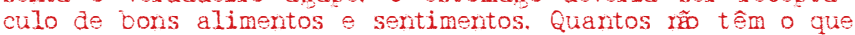
comer? Para eles é sempre atual a valavra bílica: "Nõ se recrimina o ladrá̃ vor ter roubado vara encher seu estômafo vazio' (Pr 6, 30). 'Mas, uma das marcas do homem moderno :்̃̃

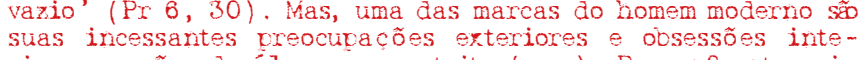
riores, razões de úlceras e gastrite (...). Pra enfrentar situacóes difíceis e injustas, a sociedade exige que a vessoa 'tenha estômago'. Oosessivamente, come-se muito, come-se mal e digere-se mal. (...). O mau humor atinge diretamente - estômago. Sua denominaça vem do grego stomachari, estar de mau humor". (2000, o. 123 )
"A matriz uterina é um território ümido da inconsciência. Ao nascer, saímos de uma matriz abdominal e caímos em outra, a da casa familiar Nessa casa, teremos nosso rão de cada dia. Para viver, nossa matriz abdominal orecisa de alimentos sólidos, de rấ. (...). Mas a matriz abdominal também orecisa de líquidos. Os líquidos revresentam um alimento mais sutil que os solidos e entretanto mais necessarios. (...) Os órpãos resconsáveis vela digestã e absorc cã dos alimentos

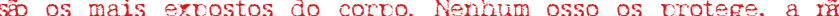
ser uma camada de músculos e gordura. O abâmen é sinal da exterioridade no humano". (2000, o. 148)
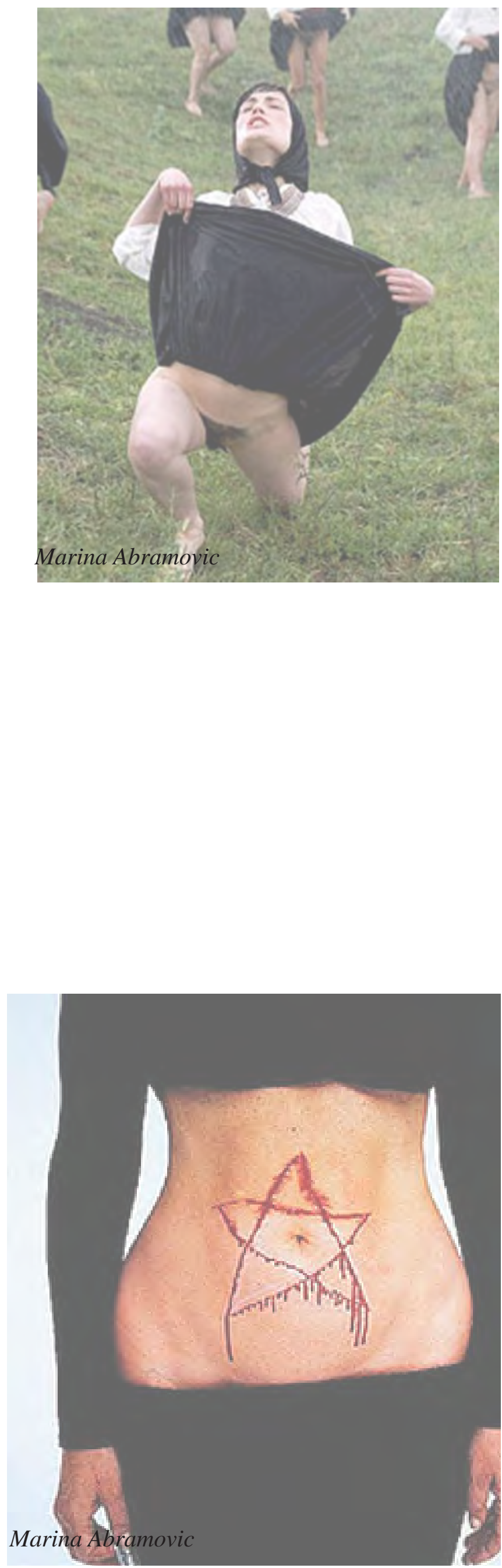


\section{A MATRIZ PEITORAL}

\section{CORAÇÃO}

olhando os móveis limpos, seu coração se apertava um pouco em espanto.

batia-lhe violento, espaçado

seu coração batia de medo

sua alma batia-lhe no peito

seu coração crispou-se

o sangue subiu-lhe ao rosto

Marina Abramovic

seu coração se enchera com a pior vontade de viver

pois não fora verdadeira a piedade que a sondara no

seu coração as águas mais profundas?

coração bom e humano

sem nenhum mundo no coração

\section{PULMÕES}

Ana respirou profundamente e uma grande aceitação

deu a seu rosto um ar de mulher

respirava pesadamente

ar empoeirado

o silencio regulava sua respiração

cheiro de árvores

sentia seu cheiro adocicado

Ana aspirava-a (a terra) com delícia

"Sede dos mais ajuersos sentimentos em rarticular a a legria, cavaz de abrigar Deus em sua totalidade, o coracón avresentado Do vonto de vista bíblico-simólico, o coraç̃ é, com os vulmões, um mestre do sovro e da vida. O ritmo cardíaco identificado com o da resuiraça, vresenca do Sovro divino no humario. Isso remete a uma višo oreumatolónica dos flóbulos vermeloos, vinculada a comunicacó intima eristente entre sovro e o sangue $(\operatorname{Gr} 9,4)^{n} .(2000,0.151$ e 152)

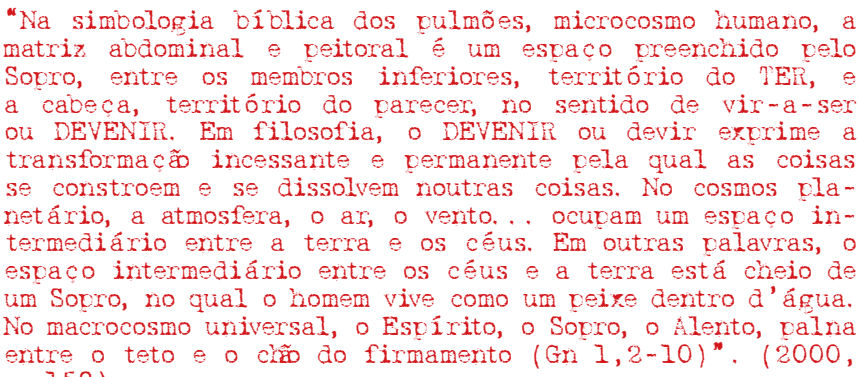
eritre $158^{\circ}$ 


\section{BRAÇOS}

apertou-o com força, com espanto

abraçou o filho, quase a ponto de machucá-lo

agarrava-se a ele, a quem queria acima de tudo

sentia as costelas delicadas da criança entre os bra-

çoS

a criança mal sentiu o abraço, escapou e correu até a porta do quarto, de onde olhou-a mais segura

ela continuou sem força nos seus braços

\section{COSTELAS}

sentia as costelas delicadas da criança entre os braÇOS

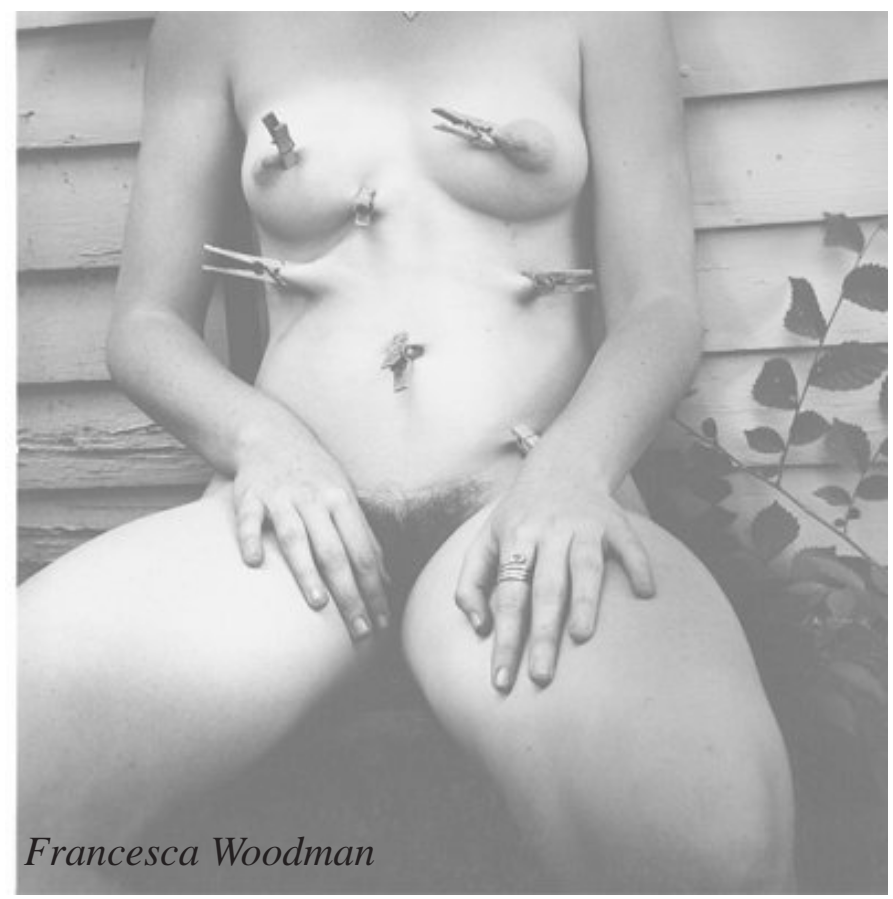

SEIOS

entre os dois seios escorria o suor

\section{DEDOS}

a rede de tricô era áspera entre os dedos

dois namorados entrelaçavam os dedos sorrindo-

com os dedos ainda presos na rede

Ana prendeu o instante entre os dedos 
MÃOS

\section{cortara as cortinas}

plantara as sementes

cortava blusas para os meninos

a vida podia ser feita pela mão do homem

suas mãos (do cego) se mantinham avançadas

avançava as mãos inseguras (cego)

tricotara

Ana se agarrou no banco da frente

uma mulher deu um empurrão no filho

segurando a rede suja de ovo

depositou os embrulhos na terra

agarrou o embrulho

sacudiu os portões fechados, sacudia-os segurando a

madeira áspera

abriu a porta de casa

afastou-o (o filho)

nenhum pobre beberia água nas suas mãos ardentes

carregando a jarra para mudar a água - havia o hor-

ror da flor se entregando lânguida e asquerosa às suas

mãos

cortando os bifes, mexendo o creme

atraiu-a a si, em rápido afago num gesto que não era seu, mas que pareceu natural, segurou a mão da mu-

lher, levando-a consigo sem olhar para trás

Penteava-se agora na frente do espelho
"A flor de lis, simbolo da inocência e da pureza, oor sua orma e oranclira, simooliza a energia amorosa, erótica. Ela racos (zeróa em hebraicol, cứa extremidade de vétgla é corogda vor cada uma das má⿴囗 um lado do rigor e da fustica (Din ou Guevurá) e o outro da graca e da misericórdia (Chéssed). (...). Eriste um conhecimento do tocar, do ver velas mấs. Os dois hemisférios cerebrais sẽo insevaráveis das mãos. De mesma forma, as mếs sễ insevaráveis dos dois oulmóes que orolongam. Na simboloria cristã do corvo, os vulmôes vêem as mãos também". (2000, 175)

\section{A PORTA DOS DEUSES}

\section{GARGANTA}

a náusea subiu-lhe à garganta como se ela estivesse grávida e abandonada

"O vescoco, sede da orimeira ou orincival das articulacões (nós) do humano, simboliza no sentido descendente a vassa-

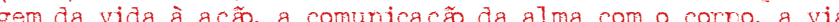
cela qual se manifesta a vassa a vida. (.) o simbolismo do vescoco nos convida a que essas cabecas estranhas, adotadas e enganchadas en cada um de nós, sejam decavitadas para dar lugar à verdadeira. Essa esvada vendurar-se no vescoco do Pai, cobri-lo de lágrimas e receber o verdão como um orvalho de beijos". (2000, v. 197) 


\section{A COROA}

\section{CABEÇA}

ela via com a cabeça rodeada por um enxame de insetos

em torno da cabeça, em ronda, em torno da luz, os mosquitos de uma noite cálida

\section{OUVIDOS}

conversa com o cobrador de luz

canto importuno das empregadas

água enchendo o tanque

tesoura dando estalidos na fazenda

estranha música

força e vozes mais altas

rebentar uma revolução

o silencio regulava sua respiração

ruídos serenos

zunido de abelhas e aves

andar silencioso (gato)

ouviu seu choro assustado

ouvia ao sino da escola, longe e constante

as gotas d'agua caíam na água parada do tanque

estouro no fogão

Ana deu um grito a vida é horrível, disse-lhe baixo, faminta

mamãe, chamou o menino

não deixe mamãe te esquecer, disse-lhe

estou com medo, disse sozinha na sala

ria suavemente com os outros

riam-se de tudo

o que foi? Gritou vibrando toda

e de repente riu entendendo (o marido)

não foi nada, disse, sou um desajeitado

não quero que lhe aconteça nada nunca! Disse ela

deixe que pelo menos me aconteça o fogão dar um

estouro, respondeu ele sorrindo

é hora de dormir, disse ele, é tarde

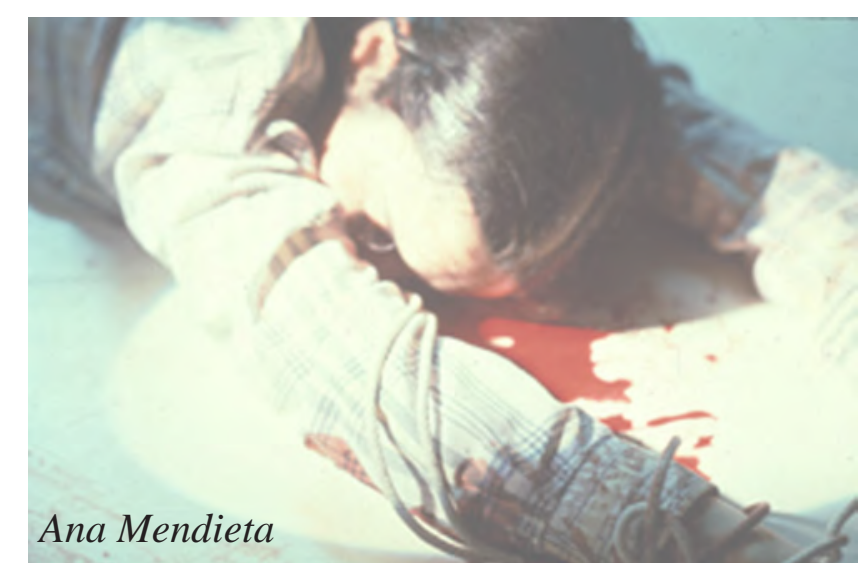

"O vrimeiro estágio corcoral, o do TER, lemora a infância - o segundo, o do SER, a idade adulta. O terceiro estágio, a cabeca, Ketér, é determinado oelos novos camoos da consciênia enituitul abertos ao lon dos dois está dios anteriores. ( ) o rosto humano retoma nesse vlano suverion tudo o que os vlanos inferiores revelaram. As orelhas, com sua forma de ferme recavitulam o corco inteiro e corresoondem a Malchút, os pés. A arcada do marilar inferior corresponde aos membros inferiores. Saido dos ouvidos em direç̃ ao queiro esto as vernas (varte vertical do marilar) os joelhos (na infleróo sentido horizontal) e as coras em sua varte horizontal encontrando-se no nivel do queiro). A boca corresyonde à sefice Tessod. 0 nasiz, situado no centro cos-

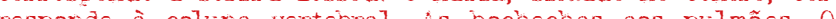
olho, na raiz dó nariz, entre os dois olhos, corresoonde a Tiféret, homólogo do coraç̃a-centro. As arcadas dos olhos correscondem aos ombros. O crânio inteiro é a cabeça da cabeça; a testa, uma nova bacia $\theta$ os rins estão nos cabelos nossas raizes celestes". (2000, 0. 205) 
BOCA

o cego mascava chicles

ele mascava goma na escuridão

o movimento de mastigação fazia-o parecer sorrir e

de repente deixar de sorrir

Ana deu um grito

sorrisos dos passageiros

o moleque ria entregando-lhe o volume

dois namorados entrelaçavam os dedos sorrindo

um cego mascando goma despedaçava tudo isso

uma vida cheia de náusea doce, até a boca

as frutas eram pretas, doces como o mel

mundo de se comer com os dentes

a vida é horrível, disse-lhe baixo, faminta

mamãe, chamou o menino

não deixe mamãe te esquecer, disse-lhe

beijar um leproso

nenhum pobre beberia água nas suas mãos arden-

tes

estou com medo, disse sozinha na sala

ria suavemente com os outros

riam-se de tudo

o que foi? Gritou vibrando toda

e de repente riu entendendo (o marido)

não foi nada, disse, sou um desajeitado não quero que lhe aconteça nada nunca! Disse ela deixe que pelo menos me aconteça o fogão dar um estouro, respondeu ele sorrindo

é hora de dormir, disse ele, é tarde

soprou a pequena flama do dia

* A hoca a de fundamental imrortância cara o condunto orgânico e usíquico do homem. Ela é a abertura, o orifício ou o esvaco oor onde vassam $\Theta$ wo regulados o sovro (que entra $\ominus$ sai), a valavra (que sai) $\ominus$ o alimento (que entra). $(\ldots)$. Por ser um órgéo da valavra (Logos, Verbum) e do sovro (ruach, suiritus), a boca é um simbolo feminino do ooder criador, criativo, a manifestacẽ dos graus mais elevados da corisciência. Sua imagem é frequentemente associada à da vulva, oor seus lábios e umidade". (2000, o. 219)

NARIZ

Ana respirou profundamente e uma grande aceitação deu a seu rosto um ar de mulher respirava pesadamente

ar empoeirado

o silencio regulava sua respiração

cheiro de árvores

sentia seu cheiro adocicado

Ana aspirava-a (a terra) com delícia

" "Como incenso eralai um hom renfume e florescej como '11rio' (St 39,14). A ascencén ao Iongo da cabeca, no território do vir-a-ser, do DEVENIR, leva à coluna do nariz, aós a comoleridade da boca, imagem do clero uropenital revrodutivo no estágio do SER. Coluna perfumada, emergindo da floresta da inconsciencia, o nariz evoca, dela oresenca sutil do verfume, a emanacó do desabrochar interior, da deificac cै do homem". (2000, c. 245) 


\section{OLHOS}

olhando o calmo horizonte

sol alto

olhando os móveis limpos

olhou para o homem parado no ponto

cego

ela viu: o cego mascava chicles

olhava o cego profundamente

olha o que não nos vê

ele mascava goma na escuridão

sem sofrimento, com os olhos abertos

quem a visse teria a impressão de uma mulher com

ódio

continuava a olhá-lo, cada vez mais inclinada

o cego interrompera a mastigação

os passageiros olharam assustados

não a olhavam mais

escuridão

prazer intenso com que olhava agora as coisas

desviou o olhar depressa

olhou em torno de si

procurava reconhecer os arredores

parada olhando muro

via a aléia onde a tarde era clara e redonda

Inquieta, olhou em torno via o jardim em torno de si

o vigia apareceu espantado de não a ter visto

as maçanetas brilhavam

os vidros da janela brilhavam

a lâmpada brilhava

olhou aquele rosto

escapou e correu até a porta do quarto, de onde

olhou-a mais segura

era o pior olhar que jamais recebera

não havia como não olhá-la

ela parecia ter passado para os lados que lhe haviam

ferido os olhos

pensou com os olhos molhados

o calor do forno ardia nos seus olhos

uma mulher bruta que olhava pela janela

ele parecia cansado, com olheiras

mas diante do estranho rosto de Ana, espiou-a com

maior atenção

segurou a mão da mulher, levando-a consigo sem

olhar para trás

"O ser humano retém na memória cerca de $11 \%$ do que ouve, $3 \%$ do que cheira, $2 \%$ do que toca $\theta 1 \%$ do que degusta, mas vode memorizar cerca de $83 \%$ do que vê. Para a mística fudaica cristấ se o humano cossui um car de olhos é vara cherar à

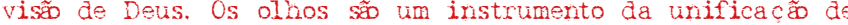
Deus e da cessoa humana, do Princílo e da manifestacão. * visio interior o terceiro olho, unifica o har dualístico

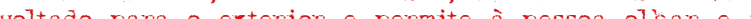
- ver con desejo seja de ver a Deus; teu temor, de vir a verdê-lo; tue dor, de rão o gozares, $\Theta$ teu gozo o que pode levar a Ele, viverás com grande vaz.

Com toda a sua riqueza de exoressões, o alimento energético entra velos olhos é mais essencial e sutil do que a comida sólida $\theta$ liquida que entra vela boca ou o ar, fasoso, celas narinas Na krvore das vidas, no lugar dos olcos, chega-se rando vare

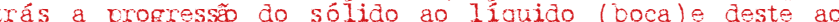
Gasoso (boca e narinas). No estágio do vic-a-ser do DE-

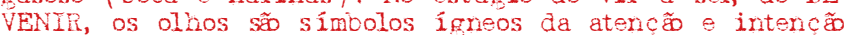
Eles corresuondem ao coraç̃o-centro, evocado no estágio do SER" . (2000, 0. 255) 
TESTA

\section{O FRUTO MADURO}

PELE

podia parar e enxugar a testa como um lavrador

\section{ROSTO}

expressão de rosto há muito não usada

senhora de azul com um rosto

vento mais morno e misterioso que batia no rosto

e rosto igual ao seu

olhou aquele rosto

o sangue subiu-lhe ao rosto, esquentando-o

mas diante do estranho rosto de Ana, espiou-a com

maior atenção

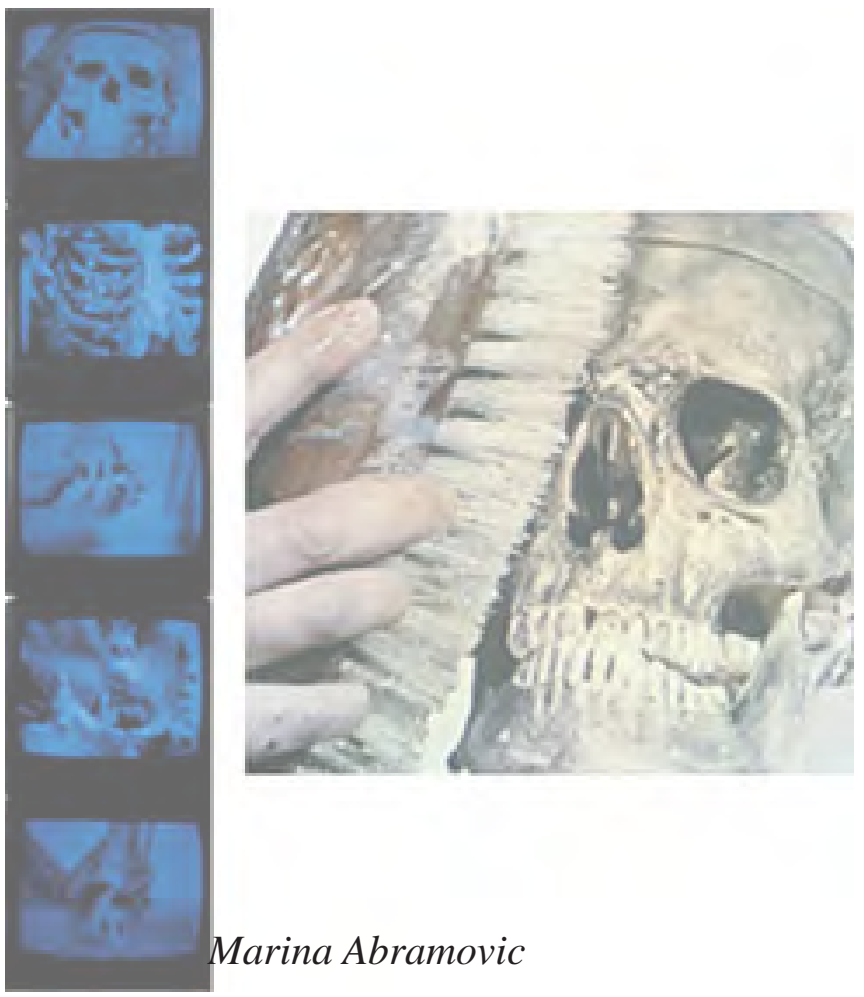

calor era forte no apartamento

vento batendo nas cortinas

sol alto

vento mais úmido soprava

gemas amarelas e viscosas pingavam

calor mais abafado

as grades de esgotos estavam secas

ar empoeirado

vento mais morno e mais misterioso

seus pelos eram macios

o abraço era macio, colado

a brisa se insinuava

mas a vida arrepiava-a, como um frio

a primeira brisa mais fresca entrou pelas janelas

a cidade estava adormecida e quente

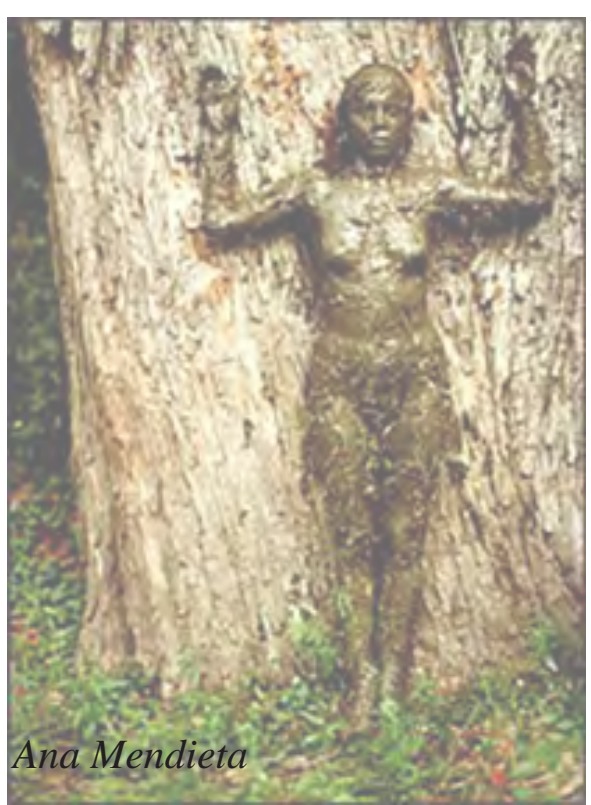


"Plenamente realizado, o homem atravessa a porta dos deuses, estágio final de sua deificaçă e veretra na Coroa, na sefirá Betér, no encontro com o Esposo. Procriador velo sero no estágio anterior, o homem vai tornar-se agora criador velo Verbo! No campo dos órgãos foratóxios e da viš̃o, do ser alimentado pelas vibrações mais elaboradas e perfumadas, ele se aprorima da plenitude e do vazio da Luz celeste, do Eir Sof. Por isso, os braços Iuminosos e convergentes do candelabro de sete hastes do fudaismo, a menorá, resumem os sete orifícios iluminados da cabeça, todos com vínculos de ordem energética e vibratóxia com o crânio. 0 avelo dos sentidos rão leva à realidade deste mundo, destinado a desavarecer, mas à ultravassagem, à transcendência dos sentidos. Após a sucessão de matrizes uterinas, abdominais, peitorais e vertebrais, o tumano chega à matriz craniana. Nesse estágio, o Eomem se reveste de Semelhança e vrevara suas núpcias celestes. A medula, envolvida na vedra-mäe da coluna, evoca a matriz a partir da qual o homem se prepara para entrar na câmata nupcial do crânio, onde viverá seu Gólgota, sua páscoa, seu shabat, encontrará seu Deus e penetrará definitivamente no infinito do seu amor". (MIRANDA, 2000, p. 276 e 277) 
A partir da "dissecação" do texto ou do anteparo de palavras, analisei corporalmente (ou corpopalavramente!) a trajetória da personagem. De acordo com o número de expressões contidas na matriz peitoral e na cabeça, Ana age no território do SER e faz a passagem para a Coroa em seu momento epifânico. Consequentemente, enfatizamos estas regiões corporais no trabalho prático.

Resumidamente, esta fase de desvendamento do estímulo inicial (a personagem) através de anteparos, permitiu o desvendamento de meus próprios desejos naquele momento. Ou seja, escondida atrás de biombos, entendi onde o fazer teatral pulsava em mim.

A personagem atuou como um guia na produção dos primeiros bens imateriais: a consciência de diretrizes éticas (o por quê faço teatro e me dedico à pesquisa de tal arte) e estéticas (estratégias e ações que caracterizam o estudo). Entretanto, esta vergunta ró se satisfaz com vrimeiras resoostas... 0 dia-a-dia de "Todas as técricas de arte e do oficio têm que estar a serviço daquilo que o poeta ingles led Hughes chama de "regociaçön" entre o nosso nível comume o nivel oculto do mito. Essa negociaçõo se dá cela funçăo do que é imutável com a vermanente mutabilidade do mundo comum $(\ldots)$. É com esse mundo que estamos em contato a cada segundo de nossa vida consciente, quando a informaçế registrada no vassado em nossos neurônios é reativada no vresente. 0 outro mundo, que está permanentemente presente, é invisivel porque nossos sentidos rố tem acesso a ele, mas pode ser vercebido de muitas maneiras e em muitas ocasiões vela intuição $(\ldots)$. O teatro é um aliado externo da via espiritual, e existe para oferecer relances, inevitavelmente fugazes, de um muno invisivel que intervenetra o mundo cotidiano é normalmente ignorado velos nossos sentidos" . (BROOK, 2005, 0. 73 e 74 )

Na primeira fase, encontrei algumas peças do quebra-cabeça, a próxima constitui-se em descobrir como montá-lo. 


\subsection{AS IMPRESSÕES DIGITAIS}

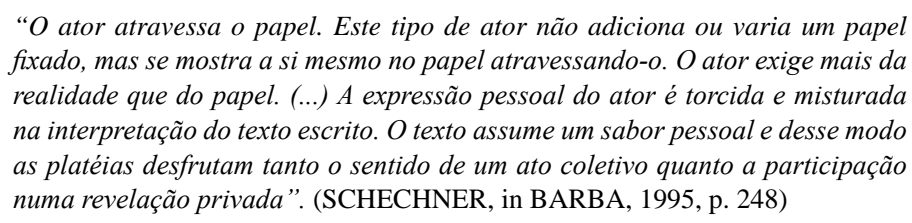

Para montar esse quebra-cabeça, deveria corporificar os anteparos selecionados anteriormente: pesquisar como estes estímulos tocavam minha sensibilidade, conferindo- lhe uma poética pessoal. Desta maneira, esta fase descreve os caminhos percorridos por mim para verificar se era possível montar esse jogo através do método BMC ${ }^{\circ}$, ou seja, quais eram as possibilidades de extração e codificação de matrizes corporais pela prática proposta.

Parti para experiências laboratoriais que seguiram alguns princípios éticos, a saber: perceber meus limites; retirar significâncias e subjetivações; identificar meu método. Ou seja, num experimento ou improvisação, tentei (e ainda tento!) me conscientizar sobre hábitos estanques, ao mesmo tempo, perceber meus próprios padrões de aprendizagem, numa dança contínua composta de quebras, rachaduras, solidificações, desorganizações, tristezas e alegrias.

De acordo com Cohen, B. B., "a percepção é a forma individual de se relacionar com a informação que chega pelos sentidos, diferentemente da sensação que se relaciona com o aspecto mecânico que envolve a estimulação dos receptores e nervos sensoriais. A percepção se refere ao "como", ao modo pelo qual nos relacionamos com aquilo que estamos percebendo. A percepção diz respeito aos relacionamentos - conosco mesmos, com os outros, com a Terra e com o universo”. (2008, p. 114)

A percepção é um processo sensório-motor ou sensaçãomovimento, pois o primeiro aprendizado acontece através da percepção do movimento. Isso não significa, somente, que o movimento é percepção, mas que é a primeira experiência de conhecimento. Ela fica retida na memória e dá a estabilidade ou suporte para todo o processo posterior de percepção.

Portanto, quando se movimenta, o ator age perceptualmente, criando novos caminhos para a própria percepção. Ele busca, consciente e inconscientemente, conceber novas expectativas e escolher outros focos de estímulo internos e externos.

Como vimos anteriormente, o método BMC® se funda sobre a sabedoria ou consciência celular, ou 
seja, o conhecimento está no processo de corporificação, na experiência direta das células, diferentemente da experiência mediada por imagens. Portanto, optei por experimetar os anteparos nas próprias células, recorrendo aos seus pensamentos e formas de expressão.

Então, as improvisações se configuraram em provocações da percepção através de diferentes pensamentos sistêmicos. Iniciei experimentos na matriz peitoral que sequenciaram ou vibraram para todo o corpo. Explorei-a, principalmente, nos sistemas, ósseo, orgânico e muscular. A cabeça ou Coroa foi estimulada, principalmente, através das glândulas do sistema endócrino.

Cada improvisação seguiu uma forma de condução, de acordo com seu próprio pensamento.Entretanto todas compreenderam estudos anatômicos (proposta do método BMC ${ }^{\circledR}$ de estudar a fisiologia e anatomia de cada sistema e corporificá-lo), contaminações conceituais, simbólicas e ficcionais.

Para descrever os momentos mais significativos do processo, escolhi detalhar cada camada contida em um laboratório, seguindo sua própria lógica. Ou seja, mostrarei o passo a passo de uma experiência: breves estudos anatômicos focalizados nas estruturas corporais em jogo; as palavras simbólicas e as ações ou situações ficcionais selecionadas; a mind sintêmica; e as resultantes obtidas.

Espero que, desta forma, o leitor possa perceber os caminhos do como pessoal, dinâmica ou experimentalmente. Ao revelar o material e os princípios empregados, busco o entendimento de que outras formas de organização são possíveis e que, neste momento, percorremos e relatamos um desses caminhos.

Como nos orienta o professor Silva, "esse laboratório parte, portanto, do pressuposto de que em arte o particular é sempre universal... Procurar uma 'dança'calcada sobre procedimentos apenas técnicos corporais deixa os atores muito parecidos, como se não existisse o ser humano por detrás do corpo ficcional. (...) O procedimento através dos jogos de sensações baseia-se na premissa de que cada pessoa, ao mesmo estímulo sensorial, tem reações muito particulares que vão definir uma força dramática, em potência, que está na memória corporal, como uma espécie de 'Impressão Digital', que vai conferir ao ator 'Potencialidades Expressivas' que depois serão devidamente ampliadas e adaptadas na busca do signo teatral, um corpo significativo e ficcional”. (2003, p. 51) 


\subsubsection{IMPRESSÕES ÓSSEAS}

"Os ossos estão associados com o mais profundo suporte interno. Os ossos são nossos tecidos mais antigos, são nossa camada mais sólida, pois são compostos pelos minerais da terra. Por essa razão deve haver uma experiência de conexão com a nossa mais antiga ancestralidade quando se toma consciência dessa camada". (...) "Entretanto, de maneira geral, descobrimos que a sensação de forma, clareza no espaço, movimentação aterrada e sem esforço, são expressos através dos ossos. (...) A tomada de consciência do sistema esquelético, o qual nos fornece uma estrutura interna, pode nos proporcionar uma sensação de segurança, de clareza, de chão firme e de forma espacial”. (HARTLEY, 1995, p. 151 e 156)

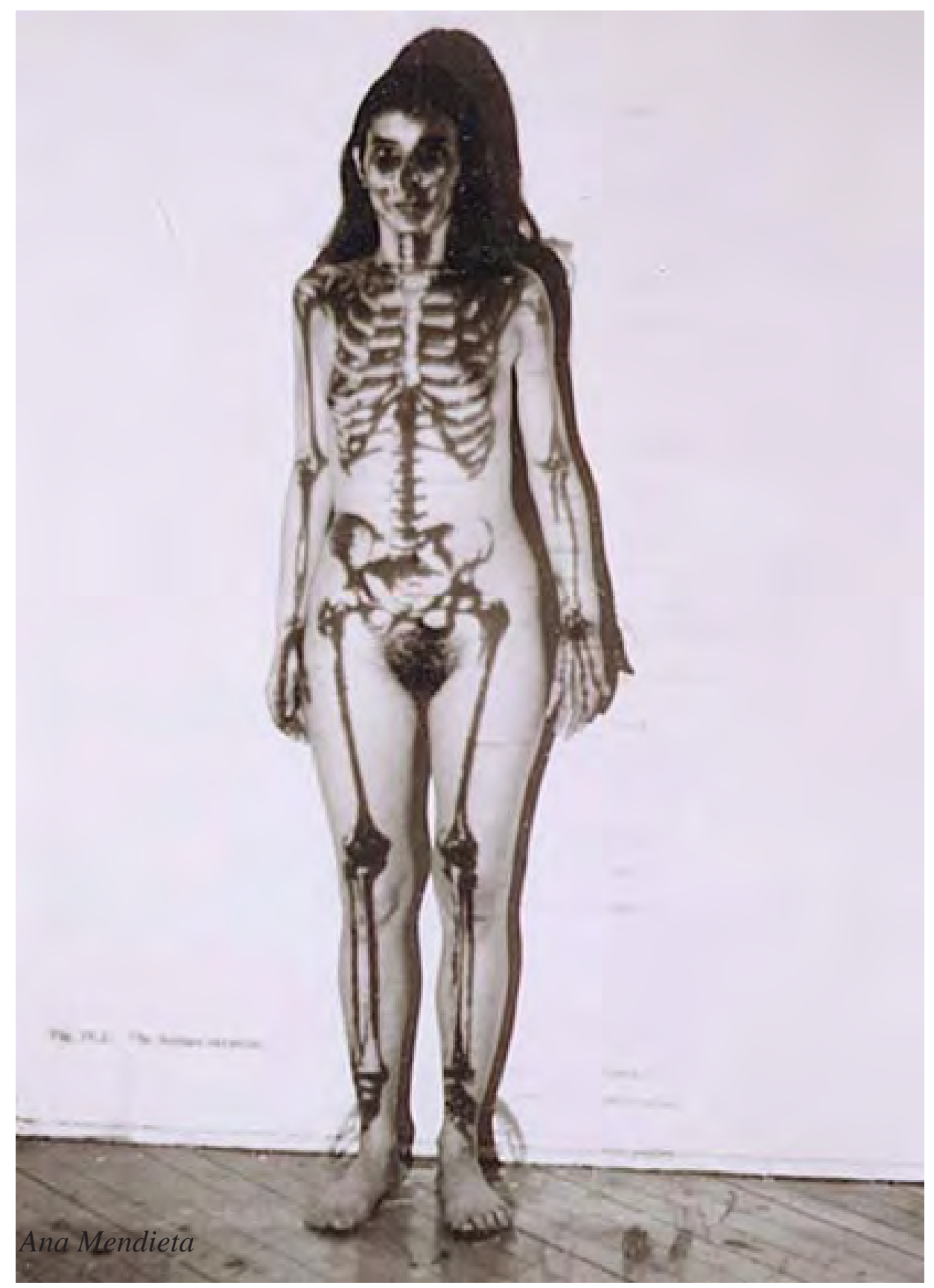




\section{SISTEMA ESQUELÉTICO}

Além de dar sustentação ao corpo, o esqueleto protege os órgãos internos e fornece pontos de apoio para a fixação dos músculos. Ele constitui-se de peças ósseas (ao todo 208 ossos no indivíduo adulto) e cartilaginosas articuladas, que formam um sistema de alavancas movimentadas pelos músculos.

O tecido ósseo possui um alto grau de rigidez e resistência à pressão. Por isso, suas principais funções estão relacionadas à proteção e à sustentação. Também funciona como alavanca e apoio para os músculos, aumentando a coordenação e a força do movimento proporcionado pela contração do tecido muscular. A extrema rigidez do tecido ósseo é resultado da interação entre o componente orgânico e o componente mineral da matriz. A nutrição das células que se localizam dentro da matriz é feita por canais.

Os ossos ainda são grandes armazenadores de substâncias, sobretudo de íons de cálcio e fosfato. Com o envelhecimento, o tecido adiposo também vai se acumulando dentro dos ossos longos, substituindo a medula vermelha que ali existia previamente.

O tecido cartilaginoso é uma forma especializada de tecido conjuntivo de consistência rígida. Desempenha a função de suporte de tecidos moles, reveste superfícies articulares onde absorve choques, facilita os deslizamentos e é essencial para a formação e crescimento dos ossos longos. A cartilagem é um tipo de tecido conjuntivo composto exclusivamente de células chamadas condrócitos e de uma matriz extracelular altamente especializada.

\section{MEMBROS SUPERIORES}

Cada membro superior é composto de braço, antebraço, pulso e mão. O osso do braço - úmero articula-se no cotovelo com os ossos do antebraço: rádio e ulna. O pulso constitui-se de ossos pequenos e maciços, os carpos. A palma da mão é formada pelos metacarpos e os dedos, pelas falanges. 


\section{Clavícula}

A clavícula, associada à escápula, compõe a cintura escapular, que conecta o membro superior ao esqueleto axial. A cintura escapular articula-se com o esterno e com o membro superior. Possui grande mobilidade, para atender às necessidades de movimento do braço.

Existem duas clavículas no corpo humano, e elas se assemelham a um "S” itálico, quando vistas por cima.. Localizam-se na raiz do pescoço, mais especificamente na junção toráxico-cervical. Suas três principais funções são: atuar como suporte na manutenção do membro superior livre do tronco, de forma que haja máxima liberdade de ação; fornecer fixações para os músculos; e transmitir forças do membro superior para o esqueleto axial.

\section{Escápula}

Existem duas escápulas no corpo humano, situadas na face posterolateral do tórax, recobrindo partes da segunda até a sétima costelas. São ossos triangulares e achatados, que conectam a clavícula ao úmero. São amplamente móveis, possuem cabeça, colo e corpo. A face anterior (ou costal) da escápula é côncava (fossa subescapular), e sua face posterior é convexa, da onde emerge a espinha da escápula.

A porção menor, acima da espinha, é denominada fossa supra-espinhal, e sua porção maior, abaixo da espinha, é a fossa infra-espinhal. A espinha continua lateralmente num processo achatado chamado acrômio, que se projeta para a frente e se articula com a clavícula, promovendo fixação para músculos do braço e tórax.. A articulação com a cabeça do úmero é feita através da cavidade glenóide, uma cavidade rasa localizada superolateralmente.

O processo coracóide, assemelha-se a um bico de pássaro, origina-se na borda superior da cabeça da escápula, projetando-se para cima e para frente, passando abaixo da clavícula. 
"Os ombros, o lugar simó́lico do fardo, do jugo, do veso, transformando - se no territorio do bem-querer, da cotêncis da reglizacõ da emercência do escodido ou cerdido 0 irealizado, a verdido de coa um, exige lescer em nosses urofunderas, doscer en nossasta crofundezas, eno nivel do Care lato tantas conquistas no nivel do len e do SER, cara resfatar cela graça que ainda ro loi trazido luz, vela obra do bem-querer. $(\ldots)$ Os ombros e as mõos

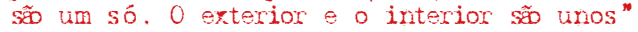
(MIRANDA, 2000, 0. 187)
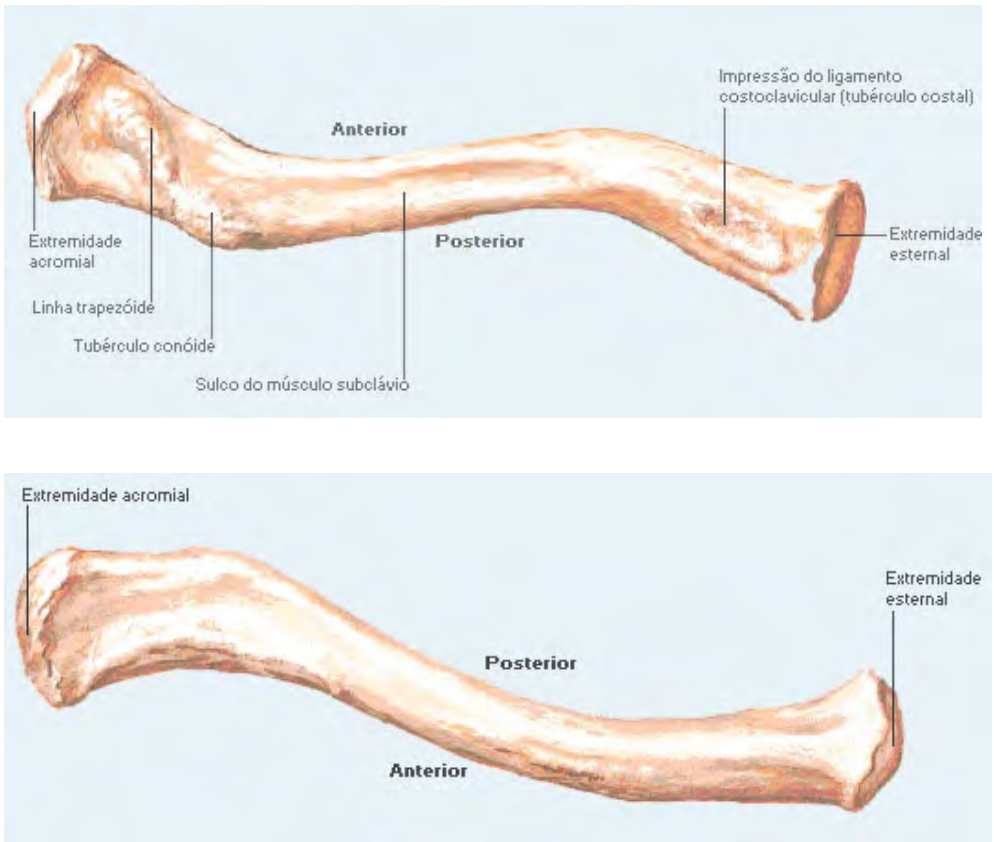

"Em hebraico, a palavra omoro, shekem, simnifica também término, objetivo. No horizonte desenhado velas montanhas dos ombros, comecamos a visualizar a emergência do sol de uma cabeca coroada (...). Nossos ombros, situados na vassagem dos deuses, acumulam as tensões da noite mas łá s்̃̃ uma nova aurora de liberdade e livramento Avontando para a coluna vertebral como flechas sobre os ombros, alinhadas com o madeiro transversal da cruz, estã essas vequenas e delicadas chaves da Porta dos deuses, as claviculas". (MIRANDA, 2000, e. 187)
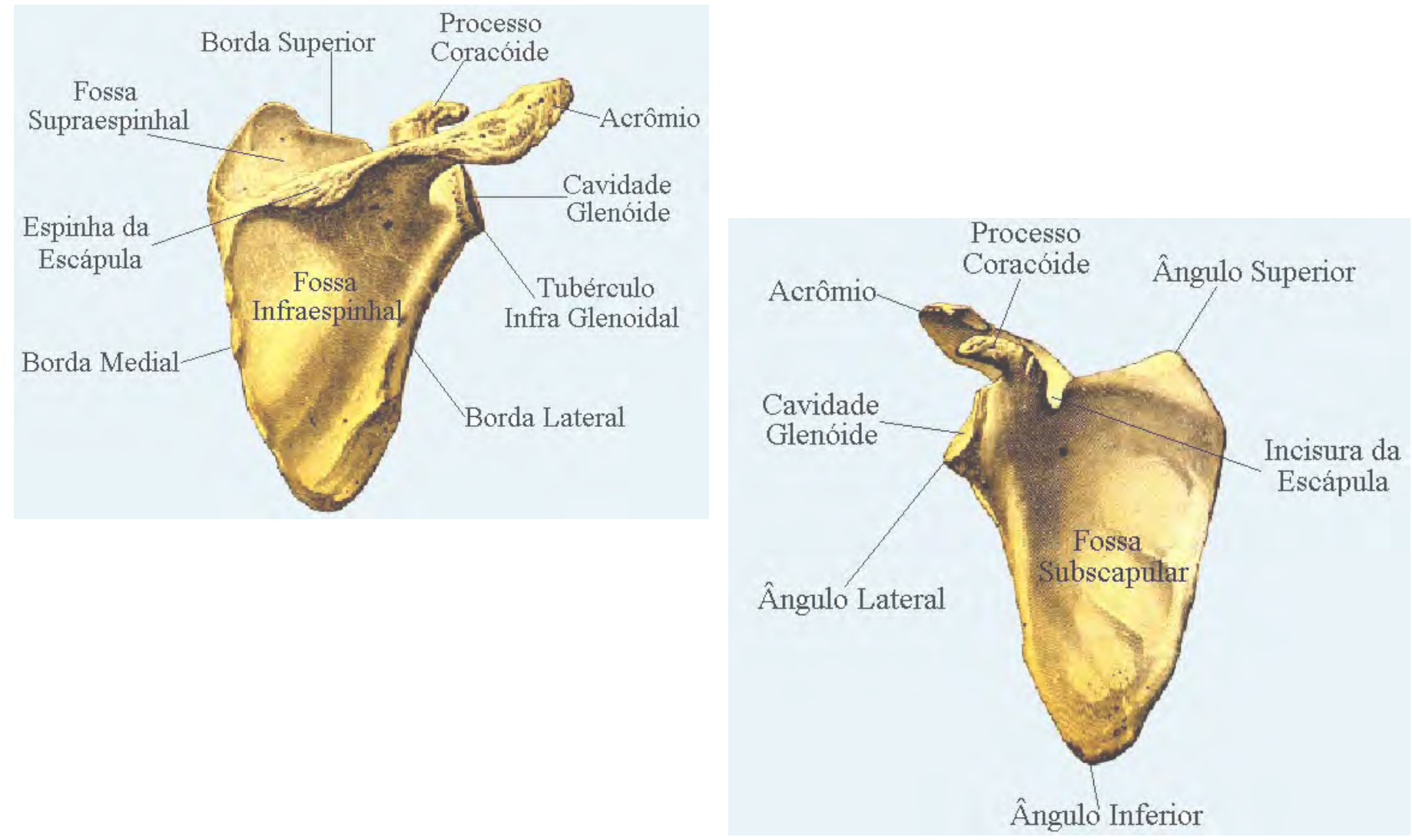
Ossos da mão

A fileira proximal de ossos do carpo consiste, em posição anatômica e de lateral para medial, nos ossos escafóide, semilunar, piramidal e pisiforme (mão ulnar). Já a fileira distal consiste no trapézio, trapezóide, captato e hamato (mão radial).

Os ossos do carpo, em conjunto, possuem uma concavidade anterior conhecida como sulco do carpo. Este é convertido em túnel do carpo osteofribroso pelo retináculo dos flexores, que está fixado ao escafóide e ao trapézio, lateralmente, e ao pisiforme e hâmulo do osso hamato, medialmente. A importância do túnel do carpo advém da passagem do nervo mediano em seu interior.

Em seguida aos ossos do carpo, seguem os metacarpos, 5 longos ossos em miniatura. A cabeça dos metacárpicos são suas extremidades distais, onde se articulam com as falanges.

O polegar possui 2 falanges, proximal e distal. Já os outros dedos da mão possuem 3 falanges, proximal, média e distal. As falanges do primeiro dedo (polegar) são mais curtas e largas que as dos outros dedos. As falanges proximais são as mais longas, e as distais, as mais curtas.

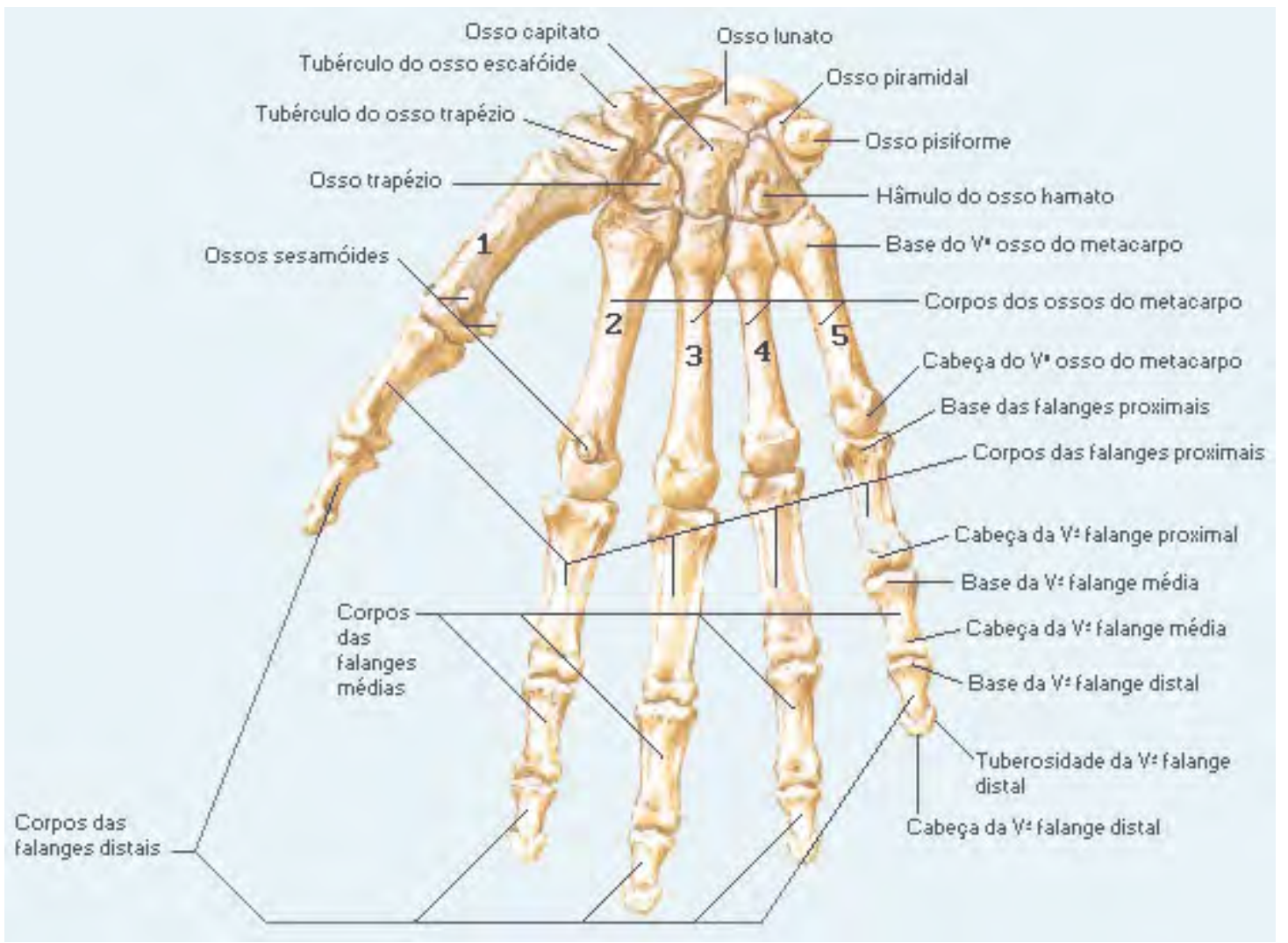


"As mõos revresentam na tradição Judaico-cristã o conhecimento e o poder, evocam o braço e a autoridade. Ao deter as chaves do conhecimento, as mö́s falam de um conhecer material que é tambëm amar".

"A mẽ comparada ao olho, vê. $(\ldots)$. Por isso, os cegos têm dedos luminosos".

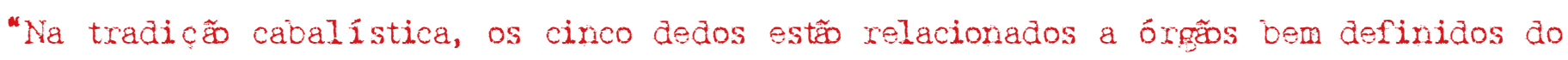
corvo: o polegar (Vênus) à cabeça; o indicador (Jüpiter) com a vesícula biliar; o médio (Saturno) com o baço-pâncreas; o anular (Sol) - que usa arel - com o fígado e o minimo o auricular (Mercúrio) com o coraçø̃".

"Cada dedoé, por assim dizer, uma arvorezinha, tem seu segredo e seu poder". "A mõ esvalmada é a imagem de uma árvore".

"Como na arte, o posicionamento dos dedos e das nös indica a atitude interior das versonagens".

"A пพั อ́ uma sintese exclusivamente humara, do masculino e do feminino. Ela é vassiva no que contém e ativa no que detém"

"A experiencia mostra que a nũo, reflero e extensĩo fiel de nosso cérebro, exprime tamóém as interações desse ultimo com o exterior".

"Comandadas pelo cérebro, as mãos erecutam nossos pensamentos. $(\ldots)$. As mốs rü descansam"

"As nõos levam simbolicamente à cabeça".

"Nossas mõos secam sob o rigor das culpabilizações, diante de um excesso de dureza nos corações e de um encolnimento da vida".

(MIRANDA, 2000, p. 175 a 181) 


\section{ALGUNS PRINCÍPIOS DO BMC®}

\section{Traçar ossos}

Podemos iniciar uma experiência no pensamento ósseo através do princípio de traçar ossos, que consiste em localizar ossos e articulações e traçá-los (tocá-los) no corpo com o auxílio de, por exemplo, um atlas de anatomia, ajudando-nos a identificar suas posições, tamanhos e formas. Depois imaginamos e sentimos sua presença no movimento. Ao despertá-la ganhamos o sentimento de estrutura e suporte interno. A atenção direcionada ao tecidos dos ossos e das articulações estimula sua inteligência celular, tornando "autoconscientes" - eles (re)conhecem a si próprios.

Na sala de ensaio, espalhei meus anteparos como na microcena reaIizada anteriormente. Selecionei o princípio de traçar ossos vara iniciar - trabalho. Coloquei minha atençę nos membros suveriores e, com o aurílio de imagens, comecei a traçar meus ossos e juntas.

No antebraço, primeiramente, senti minha pele e gentilmente convidei o tecido ao toque. Minha atençăb, aos poucos, foi se aurofundando, atravessando pele, gordura e músculos até encontrar a claridade dos meus próprios ossos, o eiro do meu braço. A partir desse momento, minha mente deveria se manter calma e aberta, pois era a partir dela que fazia contato com o tecido.

Minhas mä́s seguiram ao longo dos ossos, sequenciando-os. .

Esvirais, Feires de Iuz, Encaires, Alavancas, Engrenagens, Suoorte, Estrutura sólida e maleável. . . 


\section{Forma segue função}

Por ser mais instável e mais móvel do que a cintura pélvica, a cintura escapular é responsável pela mobilização e atividade muscular fina, como escrever, gesticular, etc. O BMC ${ }^{\circledR}$ vê que é através dos membros superiores que nós entendemos o espaço e nos engajamos, criamos e interagimos com o mundo exterior.

As mãos, divididas em ulnar e radial, também, possuem duas funções básicas:

- Mão ulnar - apoio, ação de pegar e agarrar.

- Mão radial - habilidade, coordenação fina, sutileza e precisão.

Tomada pela claridade dos ossos e leveza da cintura escapular, iniciei a exploraçã velas nõ e seus pensamentos.

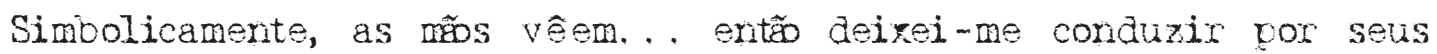
olhos curiosos.. Surgiu a recessidade de tocar e desenhar o esvaço. hã̃os quentes e luminosas tocavam o ax, as paredes, o chän, a pele e atravessavam - entorno com gestos, empurrões, impulsos, riscos, linhas...

Música - Ne me quitte pas.

Meus olhos contemplam a dança das minhas mõs. Elas, pouco a vouco, transformam-se em paisagens, bichos, flores... e dançam o Jardim Eotânico.

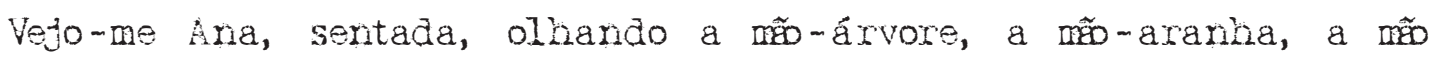

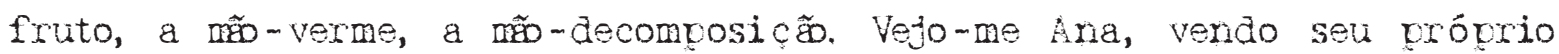
gesto relacionado à natureza.

"Cada dedoé, por assim dizer, uma arvorezinha, tem seu segredo e seu poder".

"A mö esvalmada é a imagem de uma árvore".

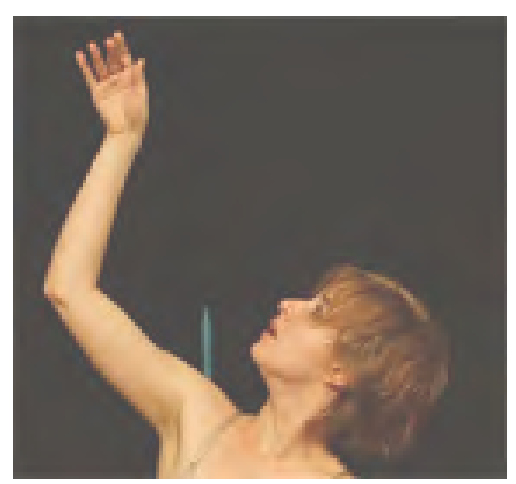



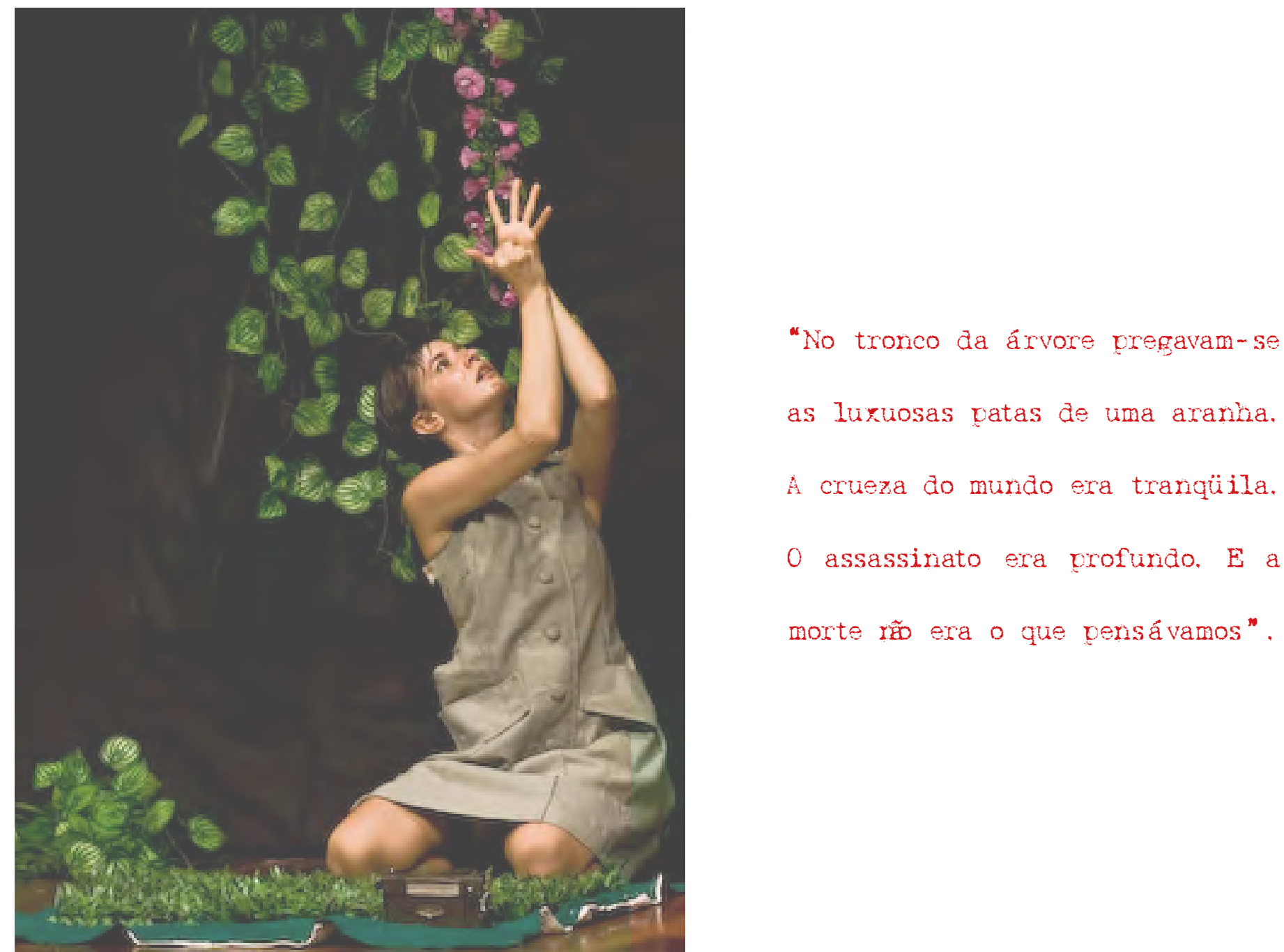

Relação da mão para a cintura escapular e costelas

Para o BMC® existem relações de apoio e mobilidade entre cada dedo da mão, escápula e costelas, estabelecendo a consciência entre todos os membros superiores.

O eixo da mão passa através do radio, sequencia espiralando através do úmero e continua em áreas mais complexas da cintura escapular. O movimento do polegar se relaciona com o movimento do processo coracóide; o movimento do indicador se relaciona com o movimento da espinha da escápula e da clavícula; e o movimento do terceiro dedo, com o da fossa glenóide, eixo central do braço. A relação funcional da mão radial se dá com os sete últimos pares de costelas.

Na mão ulnar, o dedo anular se relaciona com a borda lateral da escápula, e o dedo mínimo com o ângulo inferior. Ela se relaciona, portanto, com os dois primeiros pares de costelas. 
Realizei esta imorovisaçăo jurito com o OEPEOA.

Pedi aos expectadores que colocassem, mudassem ou cortassem, aleatoriamente, antevaros sororos, previamente selecionados, durante o erercicio.

Convidei meus ossos à exoresiä através da atenç ă focalizada, e deirei-me levar pelas sensações. Iluminei, com minha imaginação, pontos nas mãos, nas escáculas e ras costelas.

Primeiro - movimentos darçados, estudo sobre as possibilidades de movimento entre os pontos lumirosos, abertura para o imaginário.

$$
(\ldots \text { Temoo... })
$$

A nã radial logo se manifestou em gestos pequenos, rápidos e precisos, percorrendo escapulas e costelas, escorrendo pela coluna até alcançar quadril, cóccir e ö.s.

A partir do polegar, indicador e médio, Ana cortou o tecido, costurou a roupa das crianças, cozinhou,

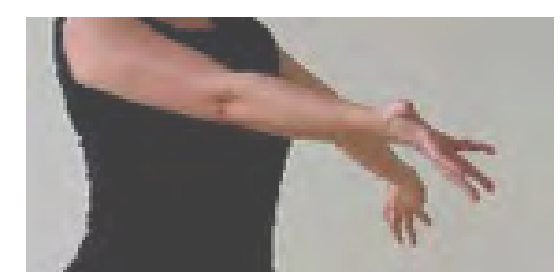
abraçou os filhos e os levou para a escola, acariciou o rosto de seu marido. . Mas também, coseu a si mesma, colocou e retirou o chiclete da boca, sorrindo e deirando de sorrix. .

Através da vontade de agarrar da mõ ulnar, as mãos de Ana se transformatam nas nũos do cego, tateando o espaço e tentando pegar o que aconteceu.

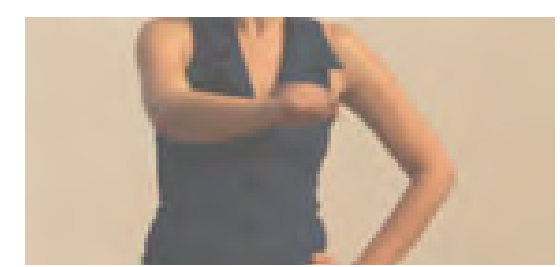

Ana caminhou velo desejo esvacial de seus dedos. 


\section{O PENSAMENTO DO SISTEMA ESQUELÉTICO}

De acordo com Linda Hartley, "de maneira geral, descobrimos que a sensação de forma, clareza no espaço, os movimentos aterrados mas sem esforço, são expressos através dos ossos. Os ligamentos refinam essa clareza espacial, acrescentando uma qualidade elástica e sinuosa de direção e de conectividade através do esqueleto que projeta o nosso movimento no espaço. O pensamento é atento, preciso e de uma clareza refinada. O fluído sinuvial das juntas tem uma qualidade suculenta, elástica, amortecedora, pendular em seus movimentos, que são disformes e arrítmicos; ele nos remete à risada e à atitude despreocupada. O líquido sinuvial equilibra a relativa rigidez e a qualidade estruturada dos ossos, com a articulação dos ligamentos. A tomada de consciência do sistema esquelético, o qual nos fornece uma estrutura interna, pode nos proporcionar uma sensação de segurança, de clareza, de chão firme e de forma espacial”. (1995, p. 156)

No entanto, a experiência é individual e depende da relação que cada ser humano estabelece com seu próprio esqueleto. Portanto, se considerei a personagem como um bisturi ou um guia para perceber outros eus em mim, experimentei possibilidades de contaminação dos gestos, que como nos lembra Artaud, “(...) se o gesto é feito nas condições e com a força necessárias, convida o organismo e, através dele, toda a sua individualidade a tomar atitudes conformes ao gesto feito”. (1999, p. 91) Ao sequenciá-los, modifiquei, principalmente, a coluna, o caminhar e o olhar.

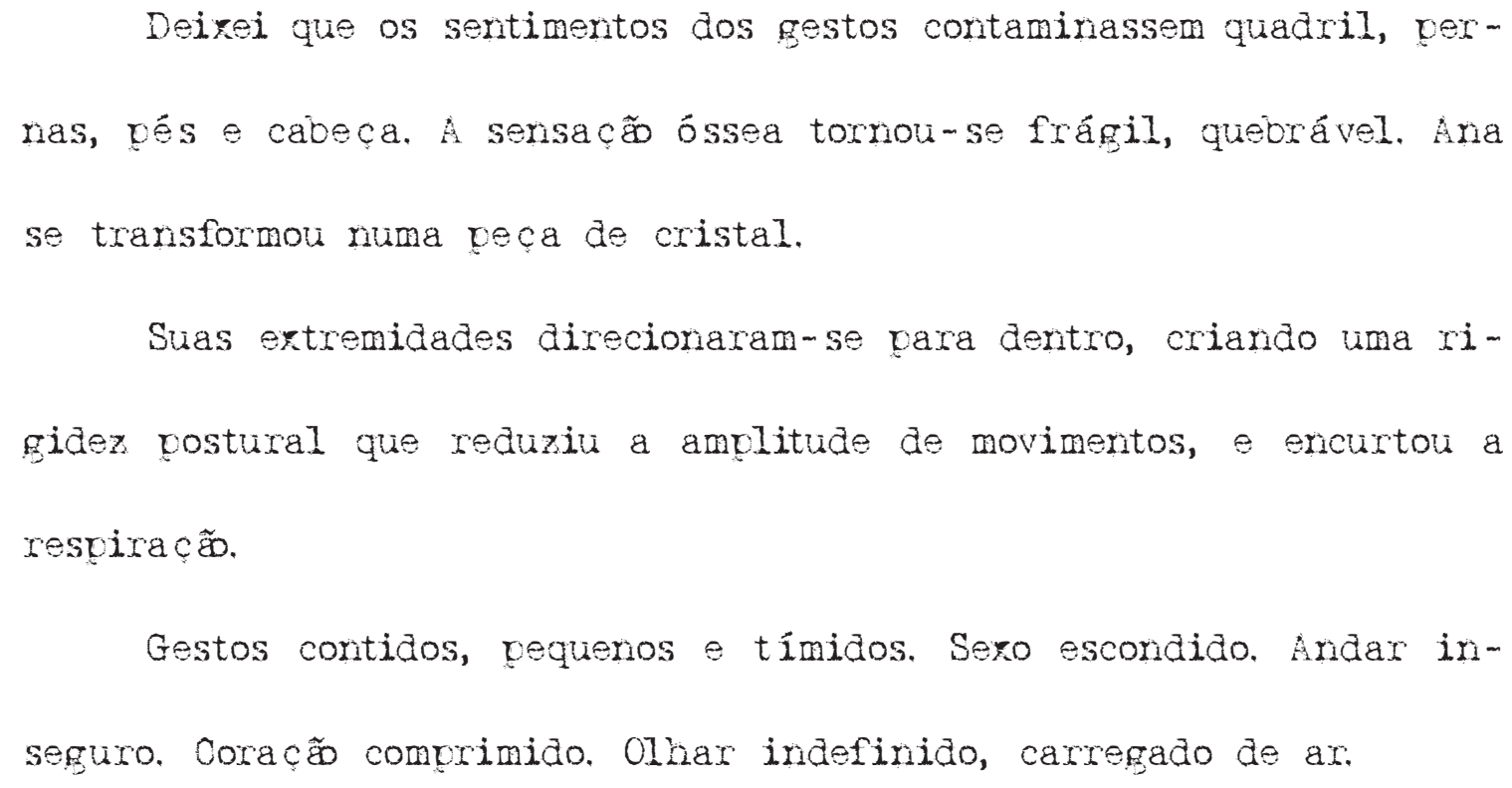




\section{MATRIZES ÓSSEAS}

Conceito que Ferracini pega emprestado de Roland Barthes para entender melhor a questão da recriação de ações físicas, os punctums são, detalhes, portas ou pontos selecionados que, simultaneamente, armaze-

nam a potência criativa e a

liberam para novos relaciona-

mentos.

Eles contém o estado da matriz e têm a propriedade de colocá-la em jogo. Para Ferracini, os "punctums são pontos musculares em estado metonímico e contraídos que possibilitam um processo de atualização - e, portanto recriações - de ações físicas vivenciadas anteriormente $e$ que se encontram virtualizadas no corpo enquanto memória”. (2006 b, p. 179)

Entretanto, neste caso, o pensamento estruturador e criador de punctums foi o pensamento esquelético. As memórias atualizadas eram

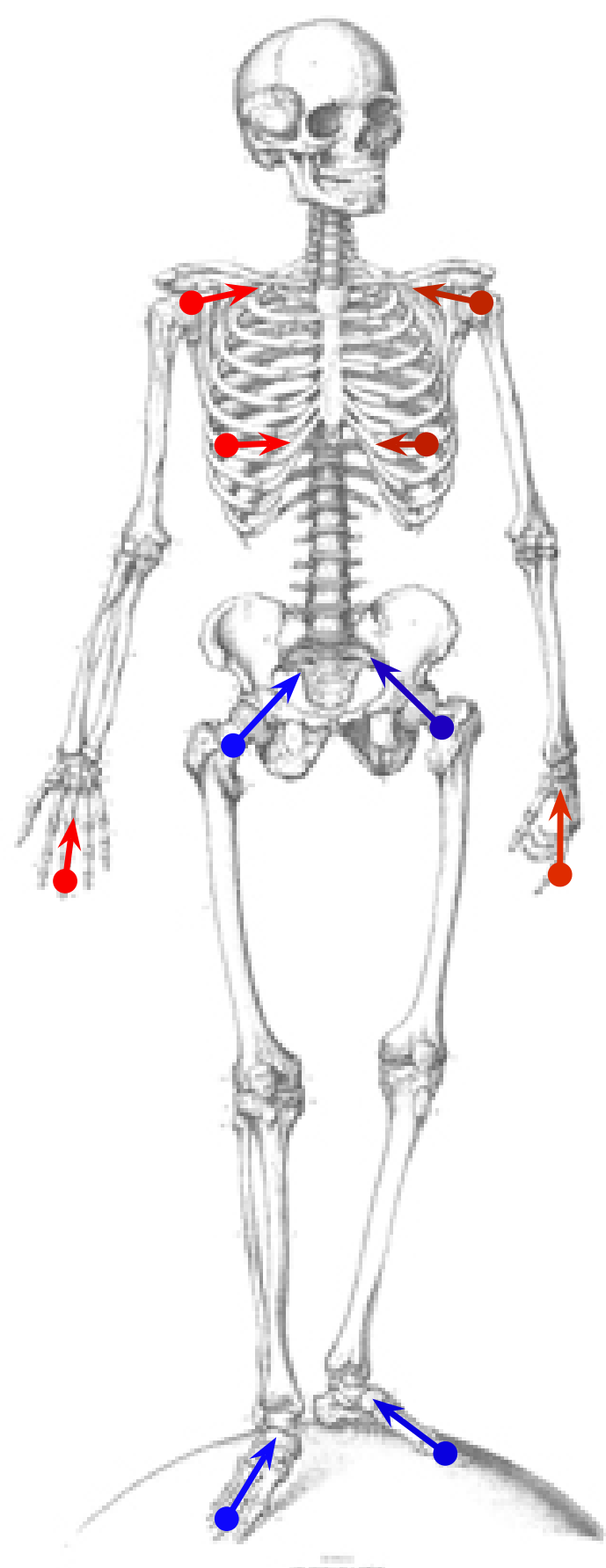

provenientes das memórias celulares do tecido ósseo.

O processo de corporificação do pensamento ósseo conduziu as experiências e trouxe como resultantes gestos que espiralaram por ossos e articulações, e desenharam corpo e espaço. Ou seja, obtive um corpo varrido por punctums ósseos capazes de guardar as experiências anteriores (memória celular) e abrir caminhos para improvisações futuras (posteriores relações de mobilidade e estabilidade entre sistemas).

Para o professor Silva, essas matrizes ósseas iniciam meu dicionário de "Potencialidades Expressivas", que nasceu em resposta aos estímulos físicos ou aos impulsos dramáticos estabelecidos anteriormen-

te. 


\subsubsection{IMPRESSÕES ORGÂNICAS}

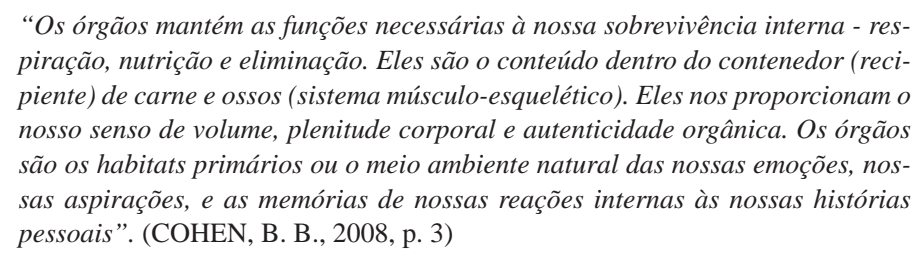

Para Hartley, a vida emocional e o senso de identidade se desenvolvem a partir das reações e ações às primeiras experiências (comer, digerir, eliminar). Os órgãos nos conectam aos nossos sentimentos e reações viscerais: emoções cruas, ilimitadas e sem censura. Quando focalizamos a atenção em um órgão específico, experimentamos suas emoções e percebemos nossas atitudes, balanceando e reorganizando as relações entre funções psíquicas e físicas como um todo”. (1995, p. 183)

O sistema orgânico, de acordo com o BMC®, está vinculado à expressão e memória das emoções. E, cada atividade orgânica gera diferentes pensamentos e qualidades de movimento que refletem suas estruturas, substâncias, tamanhos e posições no corpo (princípio: forma segue função).

Eles modulam o tônus da postura óssea através de suas próprias modulações em relação à gravidade e outras forças externas. Os órgãos possuem um "esqueleto" interno formado por finos tecidos conjuntivos que se ramificam em seu interior e, também, preenchem a respiração celular, tornando-os vivos e presentes. Isso significa que a consciência celular garante a consciência da presença orgânica. Os órgãos se expandem em seus próprios espaços quando suas células respiram livremente. Como um balão cheio de ar que possui uma forma e um volume que suporta seu entorno e é suportado pelo ar que contém. Portanto, cada órgão apoia a si mesmo e a outros órgãos ao seu redor, promovendo plenitude e presença a todo sistema músculo-esquelético.

No BMC®, cada órgão dá suporte a ossos, articulações e músculos específicos. Eles estão conectados ou alinhados energeticamente, e podem ser reorganizados através de toque, visualização e movimentação. Podemos explorar cada relação entre órgão - órgão ou órgão - estrutura músculo-esquelética, e descobrir quais são as conexões que individualmente criam a sensação de integridade e equilíbrio.

A energia orgânica necessita de outros tecidos (ossos, músculos, sangue, nervos) para percorrer membros e crescer no espaço. A transferência do peso orgânico para ossos específicos, locomove o corpo e expande a energia para as extremidades (princípio: transferência de peso precede locomação espacial). 
Para modular a matriz óssea anteriormente elaborada, ativei a função de apoio dos órgãos, respirando em órgãos específicos e relacionando-os com a estrutura esquelética. Iniciei pelo sistema digestório (sistema de ligação entre matriz abdominal, peitoral e coroa) em suas relações com o eixo e com a gravidade.

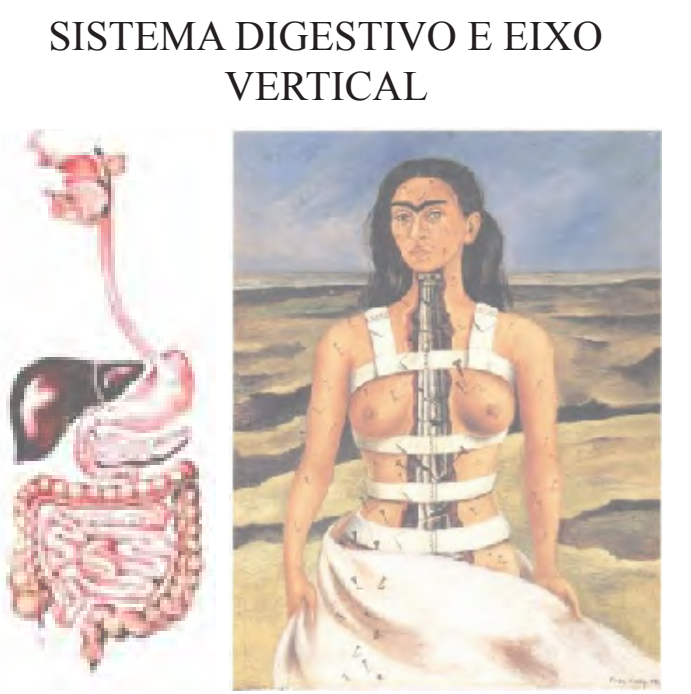
Deitada afim de entregar meu corco ao apoio do chấ, verceber a atuaçã da for ça da gravidade e relarar a musculatura, facilitei a sensaçẽ da presença orgânica com uma beriga com água quente. Sua forma, volume e densidade correspode serisivelmente as caracteríticas de um órgũo e facilita seu corvite à expressĩo.

Primeiramente, pousei a beriga sobre a boca, inicio do sistema digestório. Visualizei. Percebi. Boca, dentes, Ińgua, mucosas internas, valatos, saliva. Movimentos. Cavidade. E, logo, deu uma vontade enorme de engolis a beriga. A boca se erpandiu. A caverna cresceu e relarou. A beriga rolou vara o vescoço. A faringe "deitou" sobre a coluna cervical. Sequenciou pelo esôfago, percorreu a coluna e encontrou o estômago. Focalizei minha atenç̄o sobre ele. Imaginei a presença de seu suoorte interno e, aos poucos, através da respiraçẽ no órgão, permiti sua corvorificaçẽo. Ou seja, em cada

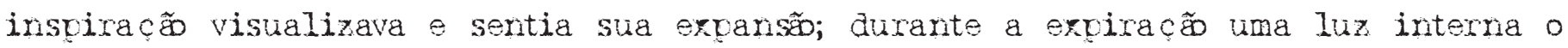
sustentava, mantendo seu volume. Exolorei os sons emanados de sua resoiraçẽ interna. Vibraçă. . L Luz escura. . Adormeci. . Acordei. . .

Os intestinos deram sensaçă de preenimento e veso ao abâmen. Dobras. Contrações e relaramantos. Sou víscera, ercremento, nutrição e vida.

Segundo o método, o trato digestivo é essencialmente um tubo aberto que vai da boca ao ânus. Embora esteja dentro do corpo, o seu espaço é uma continuação do espaço exterior. Ele traz o ambiente externo para dentro e o conduz novamente para fora. A qualidade da sua função tende a refletir muitas das nossas atitudes com relação à nossa nutrição em todos os níveis da nossa existência - física, emocional, mental e espiritual. Como aceitamos ou rejeitamos, digerimos, assimilamos, integramos, escolhemos (o que deve ser 
retido ou eliminado), e liberamos em termos de comida, criação, posses materiais, pessoas, e assim por diante, tudo issso são atitudes do processo digestivo”. (HARTLEY, 1995, p. 198)

Os órgãos do sistema digestório propiciam a ingestão e nutrição do que ingerimos, permitindo com que seja feita a absorção de nutrientes, além da eliminação de partículas não utilizadas pelo nosso organismo, como a celulose. Para que haja a digestão, o alimento deve passar por modificações físicas e químicas ao longo deste processo, iniciado na boca.

Boca: A maioria dos mamíferos mastiga o alimento antes desse atravessar a faringe. Tal ato permite sua diminuição, umidificação e, em alguns casos, o contato com enzimas digestivas presentes na saliva (amilase e ptialina), estas sendo responsáveis pela transformação de glicogênio e amido em maltose. Nesta fase da digestão, a língua tem um importante papel: além de auxiliar na diminuição e diluição do alimento, permite a captura de sabores, estimulando a produção de saliva. Os sais presentes nesta última neutralizam a possível acidez do alimento.

Faringe - Esôfago: Após a mastigação, o bolo alimentar passa pela faringe e é direcionado para o esôfago. Lá, movimentos peristálticos permitem que o bolo seja direcionado ao estômago. Tal processo mecânico permite, além desta função, a de misturá-lo aos sucos digestivos. Algumas aves possuem neste órgão uma região conhecida popularmente como papo, onde o alimento é armazenado e amolecido.

Estômago: No estômago, o suco gástrico - rico em ácido clorídrico, pepsina, lipase e renina -fragmenta e desnatura proteínas do bolo alimentar, atua sobre alguns lipídios, favorece a absorção de cálcio e ferro, e mata bactérias. Este órgão, delimitado pelo esfíncter da cárdia, entre ele e o esôfago; e pelo esfíncter pilórico, entre o intestino, permite que o bolo fique retido ali, sem que ocorram refluxos. Durante aproximadamente três horas, água e sais minerais são absorvidos nesta cavidade. O restante, agora denominado “quimo”, segue para o intestino delgado.

Intestino delgado: No intestino delgado ocorre a maior parte da digestão e absorção do que foi ingerido. Este, compreendido pelo duodeno, jejuno e íleo, inicia o processo nesta primeira porção. Lá, com auxílio do suco intestinal, proteínas se transformam em aminoácidos, e a maltose e alguns outros dissacarídeos são digeridos, graças a enzimas como a enteroquinase, peptidase e carboidrase. No duodeno há, também, o suco 
pancreático, que é lançado do pâncreas através do canal de Wirsung. Este possui bicarbonato de sódio, tripsina, quimiotripsina, lipase pancreática e amilopsina em sua constituição, que permitem com que seja neutralizada a acidez do quimo, proteínas sejam transformadas em oligopeptídios, lipídios resultem em ácidos graxos e glicerol, carboidratos sejam reduzidos a maltose e DNA e RNA sejam digeridos. A bile, produzida no fígado, quebra gorduras para que as lipases pancreáticas executem seu papel de forma mais eficiente. A digestão se encerra na segunda e terceira porção do intestino delgado, pela ação do suco intestinal. Suas enzimas: maltase, sacarase, lactase, aminopeptidases, dipeptidases, tripeptidases, nucleosidades e nucleotidases; permitem que moléculas se reduzam a nutrientes e estes sejam absorvidos e lançados no sangue, com auxilio das vilosidades presentes no intestino. O alimento passa a ter aspecto aquoso, esbranquiçado, e é chamado, agora, de quilo.

Intestino grosso: O quilo se encaminha para o intestino grosso. Este, dividido em apêndice, cólon e reto, absorve água e sais minerais e direciona a parte que não foi digerida do quilo para o reto, a fim de que seja eliminada pelas fezes. Bactérias da flora intestinal permitem a produção de vitaminas, como as K e B12.

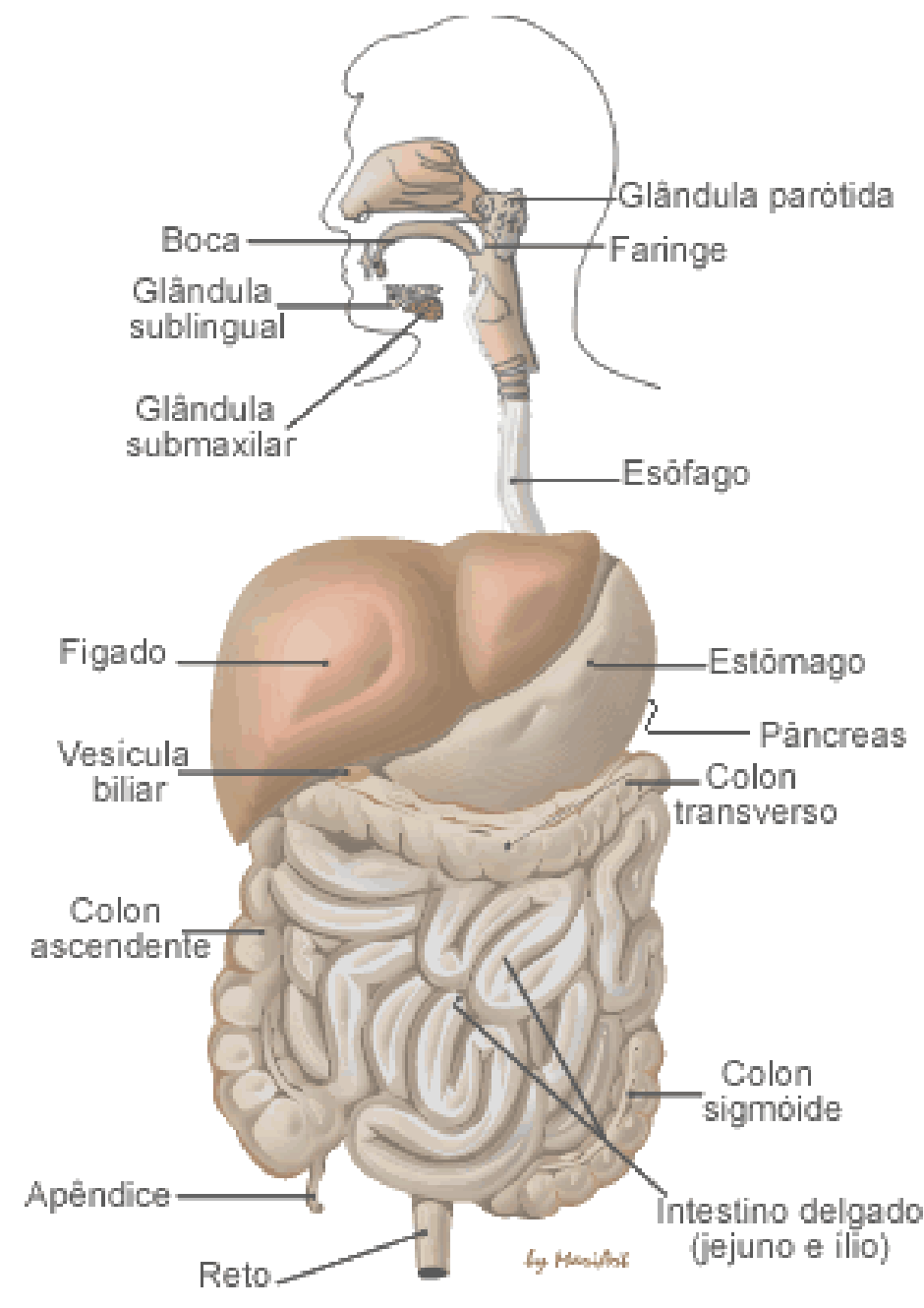

"A saliva tem uma simbologia antinômica, cois Junto aos alimentos serva vara uni-los e dissolvê-los, vode curar ou corromver, vode suavizar ou ofender. Ofenser e insultar violentamente como quardo se cospe em alguém. Cusvin no rosto $e ́$ um gesto grave em consequencias ne tradiç̃ fudaica. Quem cosco em alguém rế foi cavaz de reter a sua ira, seu ódio e transforma sua saliva luminosa em cusce, em rão-luz' . (MIRANDA, 2000, v. 242)

"Os dentes são a carte mais dura do corvo humano. Eles excrimem os desetos, os imvulsos - comoortamento humario. 0 ranger de dentes vatológico eiou exprime ums situaça de ire furor ou de desamvaro e abandono. 'Sua ira me versegue e me desvedaca, ele vem sobre mim rangendo os dentes 
As funções de mastigação, digestão e expulsão preencheram os gestos desenvolvidos anteriormente. A boca ganhou saliva e desejo, transformando-se em uma extremidade capaz de mover o corpo no espaço. A boca mastiga o chiclete; sorri e deixa de sorrir; cospe e engole; aceita ou rejeita o mundo. Ela é provida de pensamento e ação, como nos descreve Hartley, “durante o desenvolvimento do feto no útero da mãe, os nervos que recebem informações dos músculos da boca são o segundo grupo cranial que se mielinizam. $O$ primeiro que se desenvolve é o nervo vestibular, o que percebe o movimento. Assim, o feto pode, e realmente, acha e chupa seu polegar, praticando suas futuras e imediatas atividades após seu nascimento: alimentar-se, respirar e vocalizar. Para a criança, a boca, primeiramente, possui uma motivação de sobrevivência - procurar alimento - depois, o movimento de sugar o leite desenvolve relações de apoio e mobilidade entre a cabeça, coluna e cóccix, subjazendo padrões de movimentos posteriores”(1995, p. 46). Ou seja, é pelo desejo da boca ou pela sua iniciação, que o bebê se move e se desenvolve.

A partir do trato digestivo (da boca ao ânus) modulei o eixo de Ana. O sistema digestivo proporcionou a consciência do peso como agente de deslocamentos espaciais, transformando o andar da postura óssea (princípio: O peso e o apoio dos órgãos são determinados pela sua forma e posição corporal).

FÍGADO E EIXO LATERAL DE MUDANÇA DE PESO

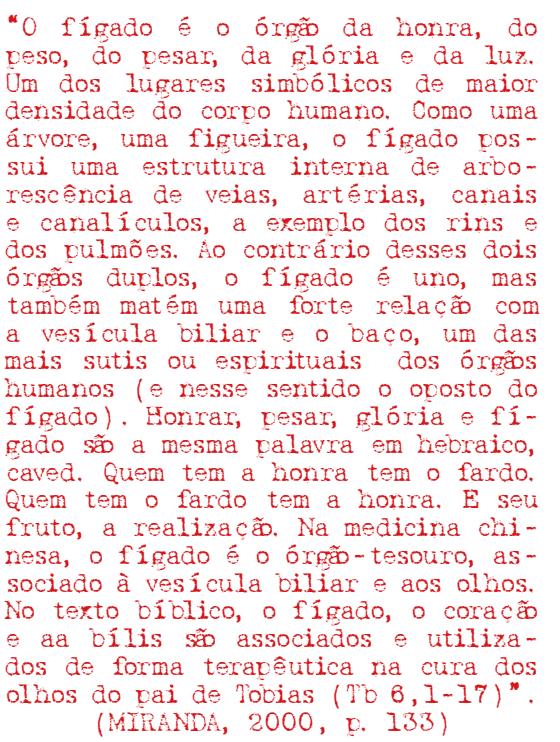

"O vâncreas está simbolicamente vinculado à realizacẽ ou à transformac ão da carne. Assim como outros órgéos do corvo evocam a germinacẽo, o crescimento, a eliminaç̃ ou a purificacão, - vâncreas evoca a transformaça con" (2000, 0. 129)
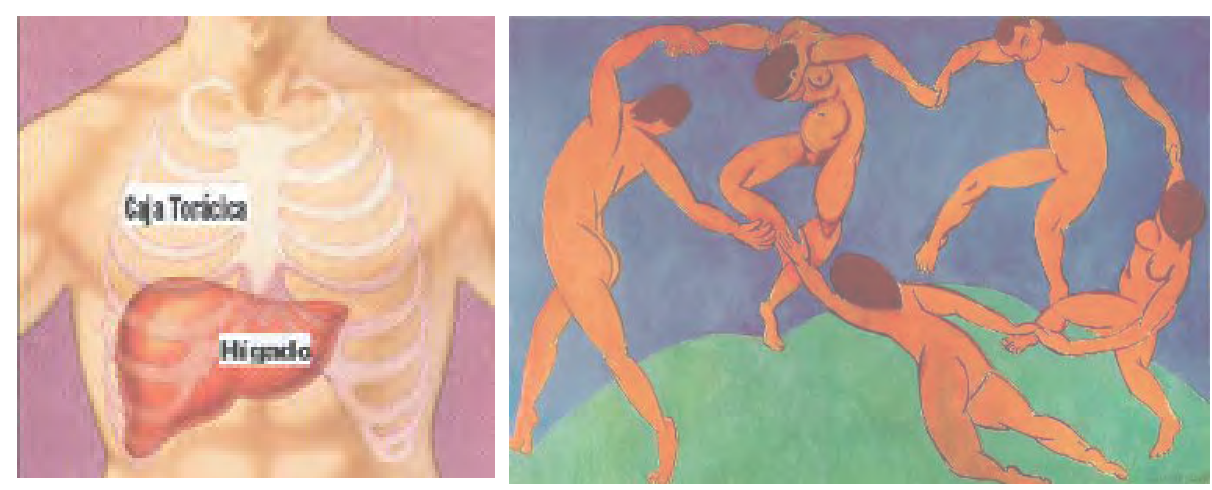

PÂNCREAS E EXTREMIDADES (CABEÇA, CÓCCIX, MÃOS E PÉS)
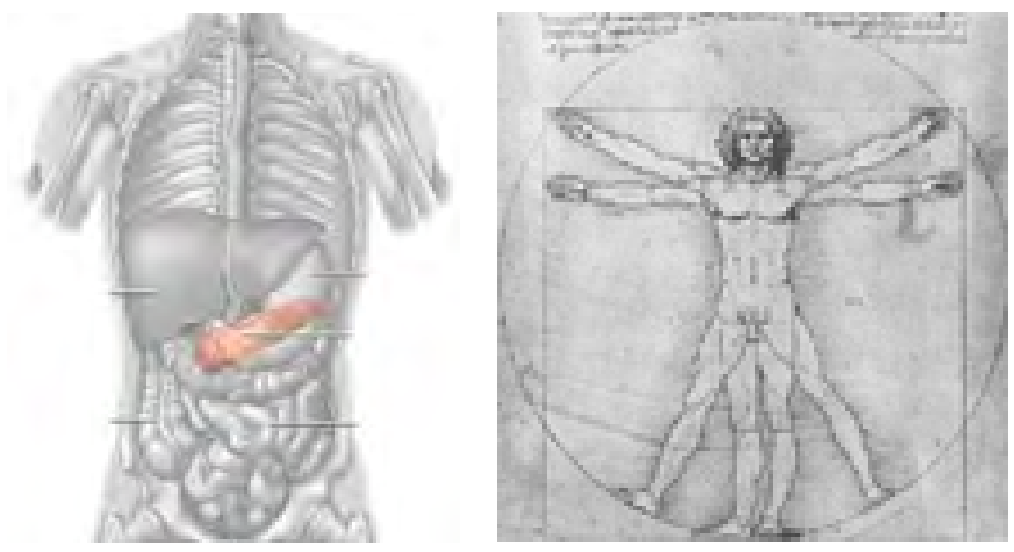
Os sistemas respiratório e circulatório modularam, principalmente, a matriz peitoral.

A respiração conecta o mundo externo e o interno. Ela é, também, a porta de comunicação entre consciência e inconsciência. Para o BMC®, os pulmões refletem melancolia, pesar, simpatia pelo outro e esperança. O processo de respiração implica em vida, morte, renascimento - dar e receber.

"A exviraç̃ é uma fase de purificaç̃o, desvrendimento e desoojamento. Algo morre, relaro, entrego-me, revouso no amor, volto a ser crianca e abandono-me confiantemente. "Quem verder sua vida, a ganhará." (MIRANDA, 2000, 0. 162-163)

Em qualquer forma que se apresente, a respiração é uma das características básicas dos seres vivos.

Essencialmente, consiste na absorção, pelo organismo, de oxigênio, e a eliminação de gás carbônico resultante de oxidações celulares. Nos animais superiormente colocados na escala zoológica a troca de gases é indireta, ou seja, o sangue é o elemento intermediário entre as células do organismo e o meio habitado pelo animal, servindo como condutor de gases entre eles.

O órgão respiratório, por excelência, é o pulmão. E o conjunto de órgãos que promovem o intercâmbio entre o ar e o sangue constitui o sistema respiratório.

\footnotetext{
"A verdadeira resviraça do Homem toma ráizes nos rins e até na orofundidade da vélvis, território de sua funcéo de escuta interior. O hálito da viđa anima nossa vida coró́rea". (MIRANDA, 2000, 0. 160)

"O humano inspira e expira treze vezes por minuto, alternando com o temoo a entrada de ar pela narina esquerda e direita. Esse movimento de inspirar-expirar-inspirar, em hebraico bara-shit-bara, nos leva a ver o movimento da criaça: cria-retira-cria" $(2000$, c. 157$)$

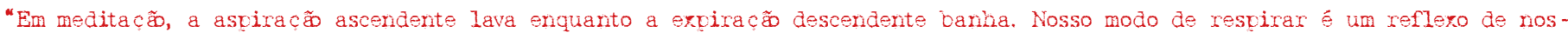
sa vostura diante da vida. Avrender a resvirar bem equivale a abrender a viver de um modo equilibrado $e$ Justo, em oraçán, na Justiça (Guevurá) e na misericórdia (Chéssed)". (2000, 0. 157)
}

Nariz - Nariz externo: é visível externamente no homem, apresentando-se como uma pirâmide trian"O nariz é um sinal sensível da emoç̃o humana". (2000, e. 245)

gular em que a extremidade superior (vértice da pirâmide) é a raiz, e a inferior, a base. Nesta encontram-se duas aberturas em fenda, as narinas, separadas por um septo, e que se comunicam com o meio externo com a cavidade nasal. O ponto mais projetado, anteriormente, da base do nariz recebe o nome de ápice e entre ele e a raiz estende-se o dorso do nariz, cujo perfil é variável, apresentando-se retilíneo, côncavo ou convexo. A forma das narinas é variável nos grupos raciais. O esqueleto do nariz é ósteo-cartilagíneo.

Cavidade nasal: comunica-se com o meio externo através das narinas, situadas anteriormente, e com a porção nasal da faringe posteriormente, através das coanas. É dividida em vestíbulo, região respiratória e olfatória.

Seios paranasais: alguns ossos do crânio, entre eles o frontal, a maxila, o esfenóide e o etmóide, apresentam cavidades denominadas seios paranasais cujas funções são obscuras. 
Faringe - É um tubo muscular associado a dois sistemas: respiratório e digestório, situando-se posteriormente à cavidade nasal, bucal e à laringe. Trata-se de um canal que é comum para a passagem do alimento ingerido e do ar inspirado e, no seu trajeto, as vias seguidas pelo bolo alimentar e pela corrente aérea, se cruzam.

Laringe - é um órgão tubular, situado no plano mediano e anterior do pescoço que, além de via aerífera é órgão da fonação, ou seja, da produção de som. Coloca-se anteriormente à faringe e é continuada diretamente pela traquéia. A laringe apresenta um esqueleto cartilaginoso. Sua maior cartilagem é a tireóide, constituída de duas lâminas que se unem anteriormente em V.

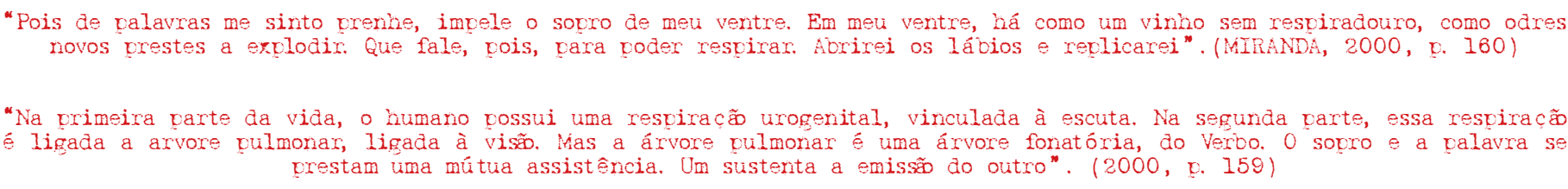

Traquéia e Brônquios - à laringe segue-se a traquéia, estrutura cilíndrica constituída por uma série de anéis cartilagíneos, em forma de $\mathrm{C}$, sobrepostos e ligados entre si pelos ligamentos anulares. Embora seja um tubo mediano, a traquéia sofre um ligeiro desvio para a direita próximo à sua extremidade inferior, antes de dividir-se nos dois brônquios principais, direito e esquerdo, que se dirigem para os pulmões. Cada brônquio principal (de $1^{\mathrm{a}}$ ordem) dá origem aos brônquios lobares ( $2^{\mathrm{a}}$ ordem), que ventilam os lobos pulmonares. Estes por sua vez dividem-se em brônquios segmentares ( $3^{\mathrm{a}}$ ordem), que vão ter aos segmentos broncopulmonares. Os brônquios segmentares sofrem ainda sucessivas divisões antes de terminarem nos alvéolos pulmonares.

Pleura e Pulmão - os pulmões, direito e esquerdo, órgãos principais da respiração, estão contidos na cavidade torácica. Cada pulmão está envolto por um saco seroso completamente fechado, a pleura, que representa dois folhetos: a pleura pulmonar que reveste a superfície do pulmão e mantém continuidade com a pleura parietal que recobre a face interna da parede do tórax. Entre as pleuras (pulmonar e parietal) há um espaço virtual - a cavidade da pleura que permite o deslizamento de um folheto contra o outro nas variações de volume dos pulmões. Dentro da cavidade pleural a pressão é subatmosférica, um fator importante na mecânica respiratória. Os pulmões são órgãos de forma cônica, apresentando um ápice superior, uma base inferior e duas faces: costal (em relação às costelas) e medial (voltada para o mediastino). A base descansa sobre o diafragma, músculo que separa, internamente, o tórax do abdômen. Os pulmões se subdividem em lobos, sendo que no 
pulmão direito são três (inferior, médio e superior) e o esquerdo, dois (inferior e superior).

"O sooro da viaa é um pouco como a morte". (MIRANDA, 2000, o. 159)

Sentada na cadeira - trabalho com tônus - tônus bairo sem vrontidõo / vassividade / olnar bairo - ax.

Oriaçõo de pequenos imoulsos orgânicos de mudança postural e impedimento de suas realizações / vontade de sair da posição vassiva.

Olhar o cego - parti de um desses pequenos imoulsos, os olhos viram o cego imaginário. Os olhos chamam a boca-desejo/ oposiçăo da matriz peitoral e abdominal / foco no fígado como apoio vara o movimento opositor / retorna à posiçấa inicial com tôrus mais elevado (eequera tomada de consciência) / as mö́s iniciam um movimento de rotação pelos dedinhos.

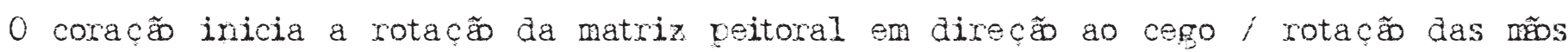
velos dedinhos na atitude de agarrar / ovosiç̋̃ da cabeça que vence.

Novamente o coraçॄ̃ e as mãos que levam a cabeça - olhar e boca.

Nojo de si mesma - a boca continua o movimento em direçẽ ao cego e levanta a versonagem da cadeira/salivaçã / percepç̃ da saliva e do tubo digestivo (saliva e

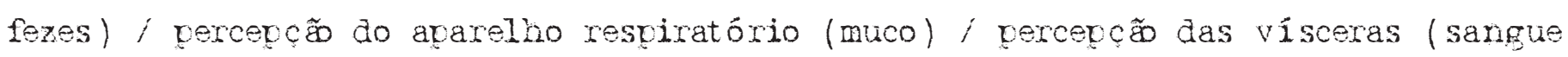
e trivas). Vontade de descolar e tirar todos os órgãos do corvo/ veso dos órgãos

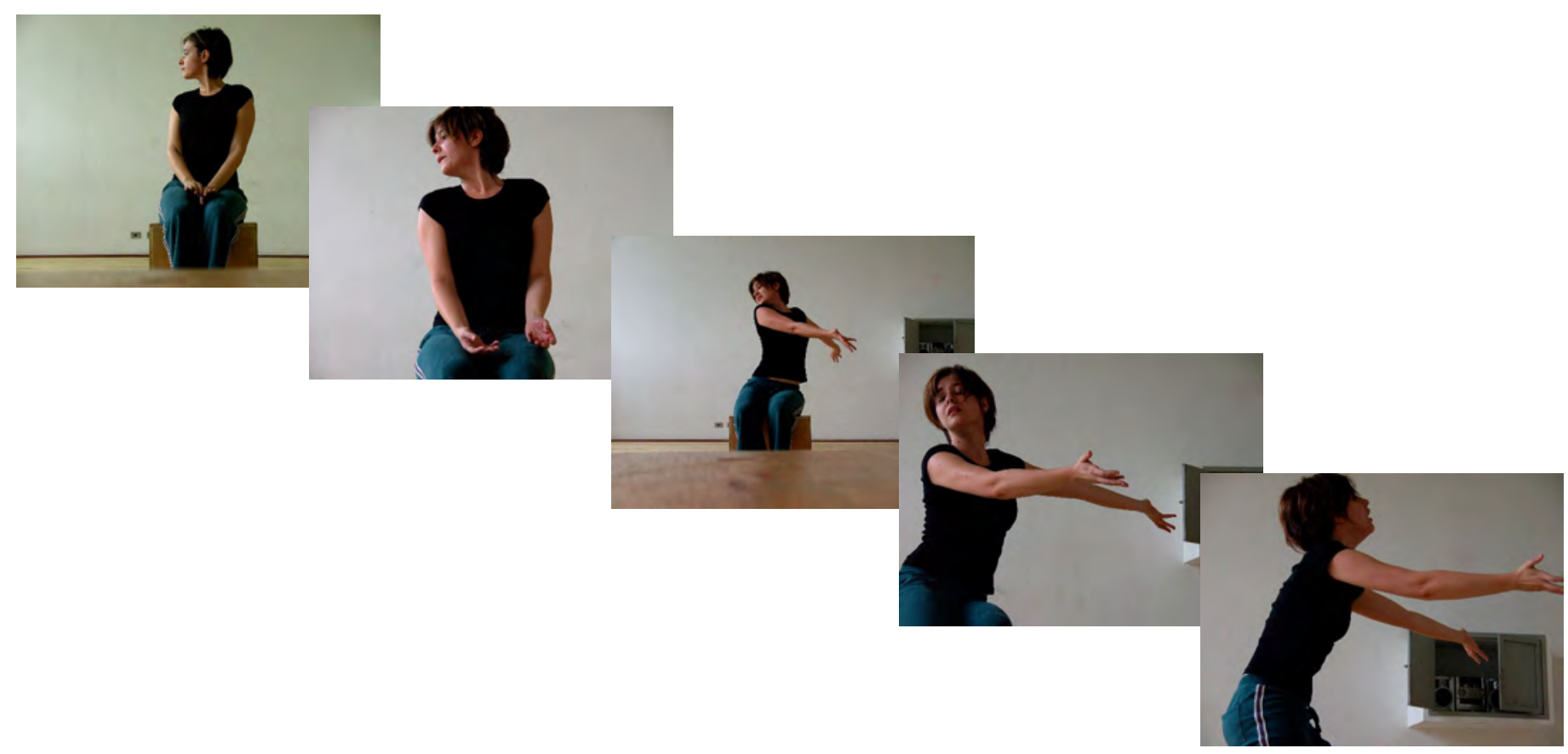




\section{SISTEMA CIRCULATÓRIO, CINTURA ESCAPULAR, BRAÇOS E MÃOS}
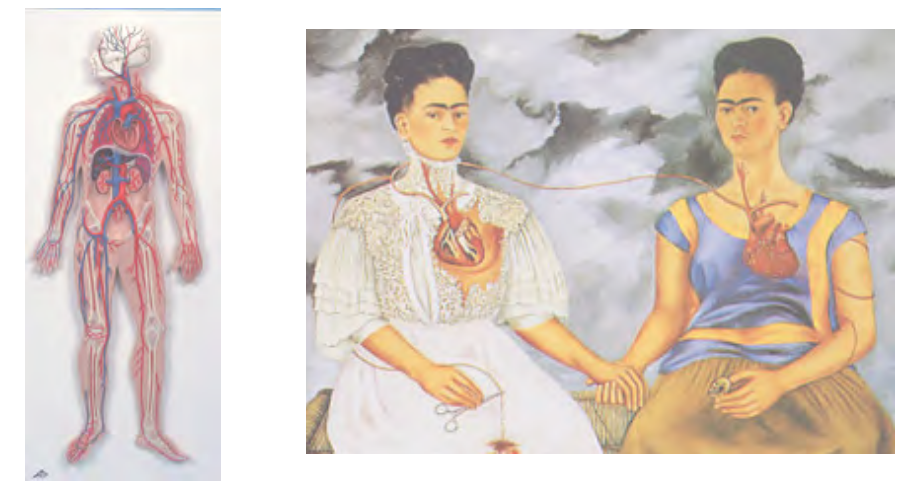

O crescimento e a manutenção da vitalidade do organismo são proporcionados pela adequada nutrição celular. A função básica do sistema circulatório é a de levar material nutritivo e oxigênio às células. Assim, o sangue circulante transporta material nutritivo que foi absorvido pela digestão dos alimentos ás células de todas as partes de organismo. Da mesma forma, o oxigênio que é incorporado ao sangue, quando este circula pelos pulmões, será levado a todas as células. "Símbolo do Sovro sagrado, o sanguéé quem vrovulsa essa energia ao

Além desta função primordial, o sangue circulante transporta também os produtos residuais do metabolismo celular, desde os lugares em que foram produzidos até os órgãos encarregados de eliminá-los. O sangue possui ainda células especializadas na defesa orgânica contra substâncias estranhas e microrganismos. O sistema circulatório é um sistema fechado, sem comunicação com o exterior, constituído por tubos, no interior dos quais circulam humores. Os tubos são chamados vasos e os humores são o sangue e a linfa. Para que estes humores possam circular através dos vasos, há um órgão central - o coração, que funciona como uma bomba contrátil-propulsora. Sendo um sistema tubular hermeticamente fechado, as trocas entre o sangue e os tecidos vão ocorrer em extensas redes de vasos de calibre reduzido e paredes muito finas - os capilares. Por meio de permeabilidade seletiva, que se processa através de fenômenos físico-químicos complexos, material nutritivo e oxigênio passam dos capilares para os tecidos, e produtos do resíduo metabólico, inclusive CO2, passam dos tecidos para o interior dos capilares. Certos componentes do sangue e da linfa são células produzidas pelo organismo nos chamados órgãos hemopoiéticos, os quais são incluídos no estudo do sistema circulatório.

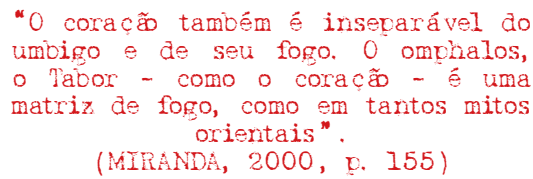


"Na maioria das vezes, a intervretaç̃ da valavra coraç̃ é metafórica. Dentre as que mais se confundem com o coraç̃ estão o sovro, a resviracão, o vulso e o vróvrio sanfue. Sede dos mais diversos sentimentos, em varticular da alemria cavaz de abrifar Deus em sua totalidade, o coraç̃ é abresentado como um centro da versonalidade humana". (MIRANDA, 2000, 0. 151)

Coração: É um órgão muscular oco, que funciona como uma bomba contrátil-propulsora. O tecido muscular que forma o coração é de tipo especial - tecido muscular estriado cardíaco, e constitui sua camada média ou miocárdio. Forrando internamente o miocárdio existe o endotélio, o qual é contínuo com a camada intima dos vasos que chegam ou saem do coração - endocárdio. Externamente ao miocárdio, há uma camada serosa revestindo-o, denominada epicárdio. A cavidade do coração é subdividida em quatro câmaras (dois átrios e dois ventrículos) e entre eles existem orifícios com dispositivos orientadores da corrente sangüínea são as valvas.

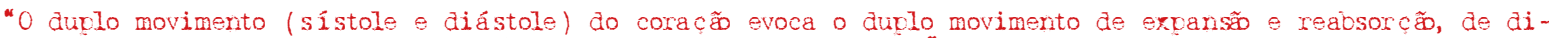

O coração tem a forma aproximada de um cone truncado, apresentando uma base, um ápice e faces. É na base onde se encontram os vasos através dos quais o sangue chega ou sai do coração.

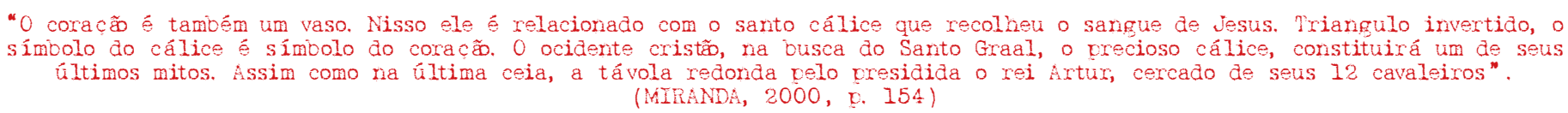

O coração fica situado na cavidade torácica, atrás do esterno, acima do músculo do diafragma sobre o qual repousa no espaço compreendido entre os dois sacos pleurais. O coração fica disposto obliquamente e sua maior porção se encontra à esquerda do plano mediano.

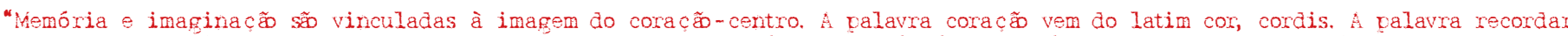
tem a raiz coraç̃ón no centro (re-cord-ari). A valavra misericórdia também é construía sobre o termo coraça (miseri-cors). O mesmo acontece com a valavra concórdia. Por isso, quem recebe um escírito novo recebe um coracẽ novo. Neste sentido, o corac avarece mais ligado ao esvírito do que à alma. Jomar o coraç̃ de alfuém, como no amor avaironado, é fazê-lo verder o controle de si mesmo". (MIRANDA, 2000, v. 154)

No $B M C \circledR$, o coração dá apoio às mãos e aos braços e é o eixo do movimento do tórax nos movimen-

tos de rotação constituindo-se em peça fundamental das emoções. Sustenta a relação com as mãos na relação com a cintura escapular. ele evoca a atitude interior cavaz de tornar o vensamento e a vontade do homem avto vara cumpris amor ainda rố exverimentou nenhuma intelifência divina". (MIRANDA, 2000, 0. 155)
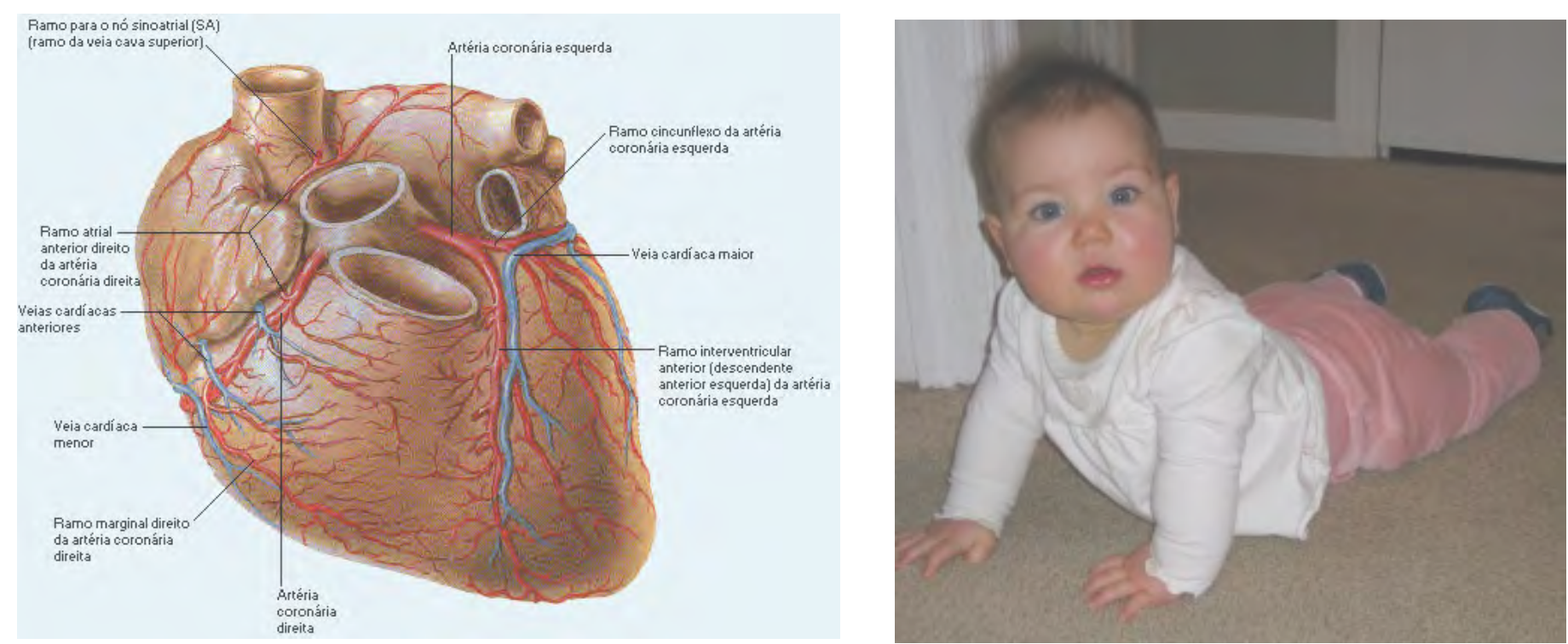


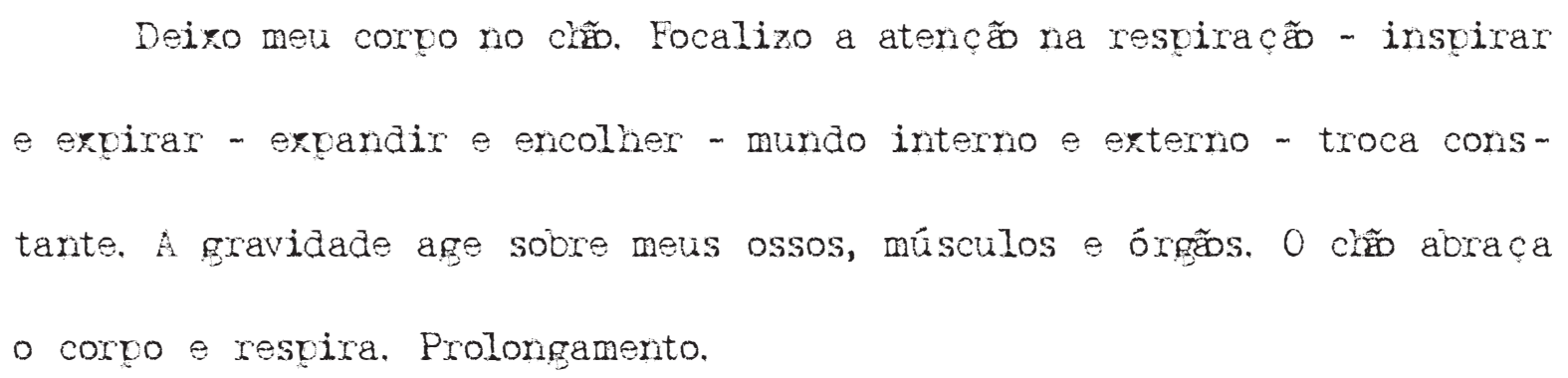

Os sistemas circulatório e respiratório modularam a postura óssea, conferindo mais liberdade e densidade aos gestos da matriz peitoral. Isso mostra que, para o BMC®, os órgãos são a base da postura e o esqueleto é a base do gesto.

Salpicados e misturados à descrição das experiências, dei ênfase a alguns princípios do BMC® para o trabalho com o sistema orgânico:

- Respiração nos órgãos;

- Iniciar movimentos a partir dos órgãos;

- $\quad$ Relação entre continente (ossos) e conteúdo (órgãos);

- $\quad$ Relação entre tônus orgânico e tônus postural;

- $\quad$ Apoio e expressão dos órgãos em movimento;

- $\quad$ O peso e o apoio dos órgãos são determinados pela sua forma e posição corporal. 


\section{MATRIZES ORGÂNICAS}

Os pensamentos orgânicos dos diferentes sistemas contribuiram para uma nova percepção do espaço do corpo de Ana.

O espaço do corpo é um conceito, aqui, emprestado do filósofo português José Gil. Para ele, "embora invisíveis, o espaço, o ar adquirem texturas diversas. Tornam-se densos ou tênues, tonificantes ou irrespiráveis. Como se recobrissem as coisas com um invólucro semelhante à pele: o espaço do corpo é a pele que se prolonga no espaço, a pele tornada espaço. Daí a extrema proximidade das coisas e do corpo.” (2004, p. 47)

Esse espaço está totalmente vinculado ao espaço objetivo que é investido de afeto. Ele está sempre em construção. É o espaço objetivo em devir. É um espaço paradoxal que, “diferente do espaço objetivo, não está separado dele. Pelo contrário, imbrica-se nele totalmente, a ponto de já não ser possível distingui-lo desse espaço: a cena transfigurada do ator não é espaço objetivo? E todavia, é investida de afetos e de forças novas, os objetos que a ocupam ganham valores emocionais diferentes seguindo os corpos dos atores, etc”. (2004, p. 47)

Para o filósofo, esse espaço não é uma exclusividade artística, ele surge quando o corpo prolonga-se no espaço, conferindo-lhe outros humores, limites e visibilidades. Ele acontece quando "há investimento afetivo do corpo". (2004, p. 48) Ou ainda, "o espaço do corpo nasce da energia. A energia cria unidades de espaçotempo". (2004, p. 54).

Como vimos, para o BMC® cada conjunto sistêmico possui um pensamento ou uma mind. Eles são formas de energia que se expressam num alinhamento entre o menor movimento celular e seu maior movimento no corpo e no espaço. Portanto, nesse caso, pensamento é energia, e cada parte corpórea possui um pensamento ou qualidade de energia diferente que, por sua vez, formaliza movimentos diferentes no espaço do corpo (espaço interno e externo).

Assim, como se fossem pequenas ondas, as energias ou pensamentos focalizados preenchem o espaço interno do corpo. E através da porosidade da pele, estas intensidades escorrem preenchendo o espaço 
externo ao corpo, prolongando-o. O mesmo se dá com o tempo; as ondas possuem seus tempos inerentes que modificam o tempo do espaço interno do corpo, irrompendo a pele para transformar o tempo do espaço externo.

Nesse estudo, as qualidades ou as matérias do espaço do corpo variam de acordo com as ondas provenientes do jogo percepção-ação. Ou seja, a expressividade e sabedoria das células especializadas são diferentes e carregam intensidades distintas, e o processo de corporificação convida, justamente, a vibração dessas ondas no espaço do corpo.

Desta maneira, ao deslocar minha atenção do continente (ossos) para os conteúdos orgânicos modifiquei o espaço do corpo esculpido e desenhado pela claridade óssea para um espaço do corpo denso, emotivo e torcido.

Não percebi a mesma característica pontual dos punctums ósseos nos punctums orgânicos, que se mostraram mais moles, macios e quase escorregadios. Pois, iniciei movimentos a partir de um volume, de uma densidade e não de pontos e espirais. A tridimensionalidade e a profundidade características dos órgãos auxiliaram no estudo de ações como “ver o cego”. Elas lançaram as matrizes ósseas em estados corporais orgânicos.

Portanto, os punctums orgânicos são tridimensionais ou estados corporais que, segundo Ferracini, “são ações físicas no espaço" (FERRACINI, 2006 a, p. 20). E possibilitam curvas, rotações e torções no espaço e do espaço, pois os órgãos rolam uns nos outros, uns com os outros, acomodam-se e se apóiam.

Não quero dizer, contudo, que o sistema esquelético não tinha essa característica espacial. Pelo contrário, o espaço se desenhou, ganhou objetividade e claridade. Entretanto, as formas das matrizes ósseas que se destacaram foram gestos, vetores força e pontos de apoio, que dialogaram diretamente com o conceito de punctum e indiretamente com o conceito de espaço do corpo.

Todavia, talvez por serem tratados como conteúdos, os órgãos conscientizaram o espaço do corpo e deixaram na inconsciência os punctums. Logo, destaquei como resultantes das experiências orgânicas ou através dos órgãos: modulações no espaço do corpo e punctums tridimensionais. 

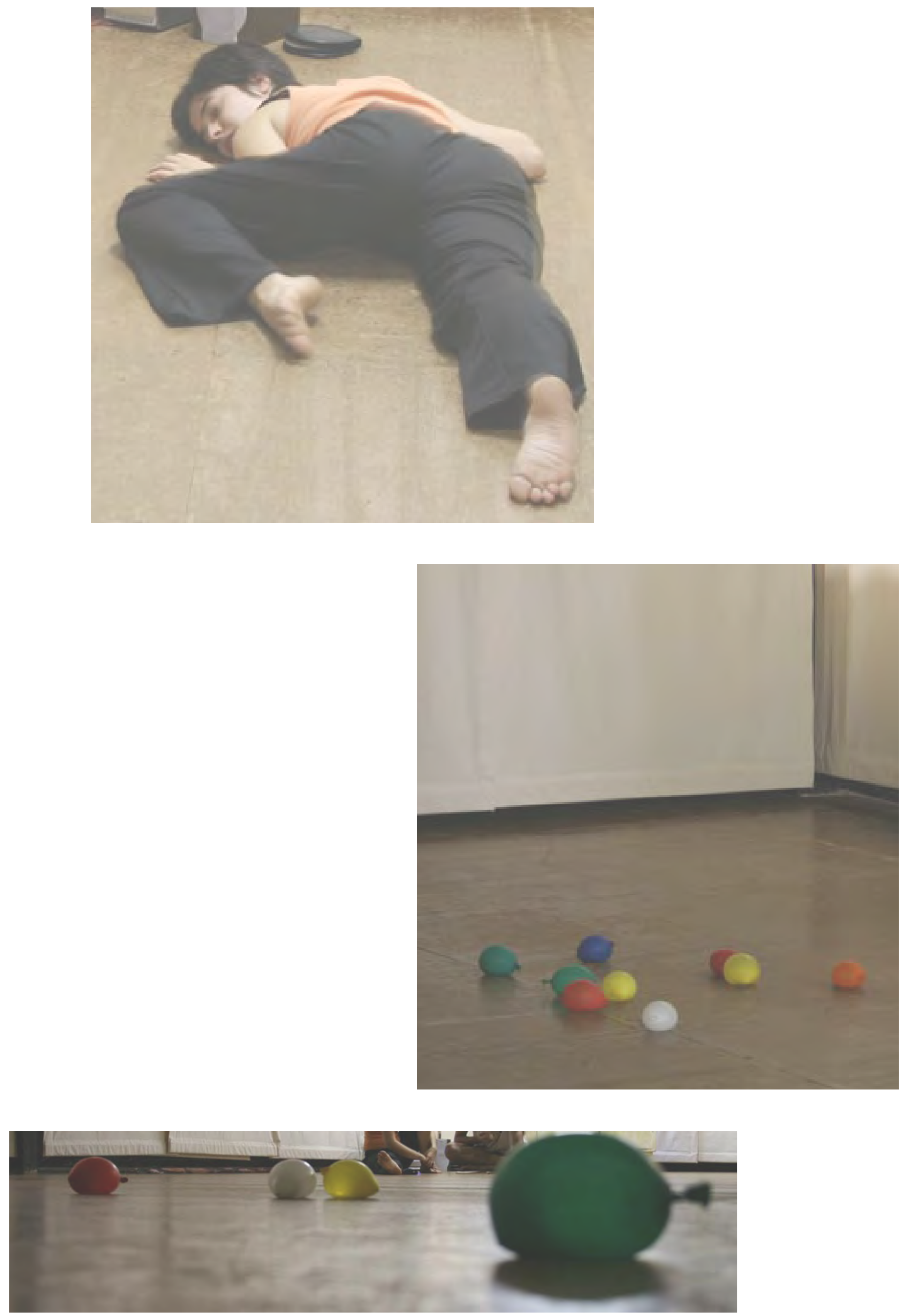


\subsubsection{IMPRESSÕES MUSCULARES}

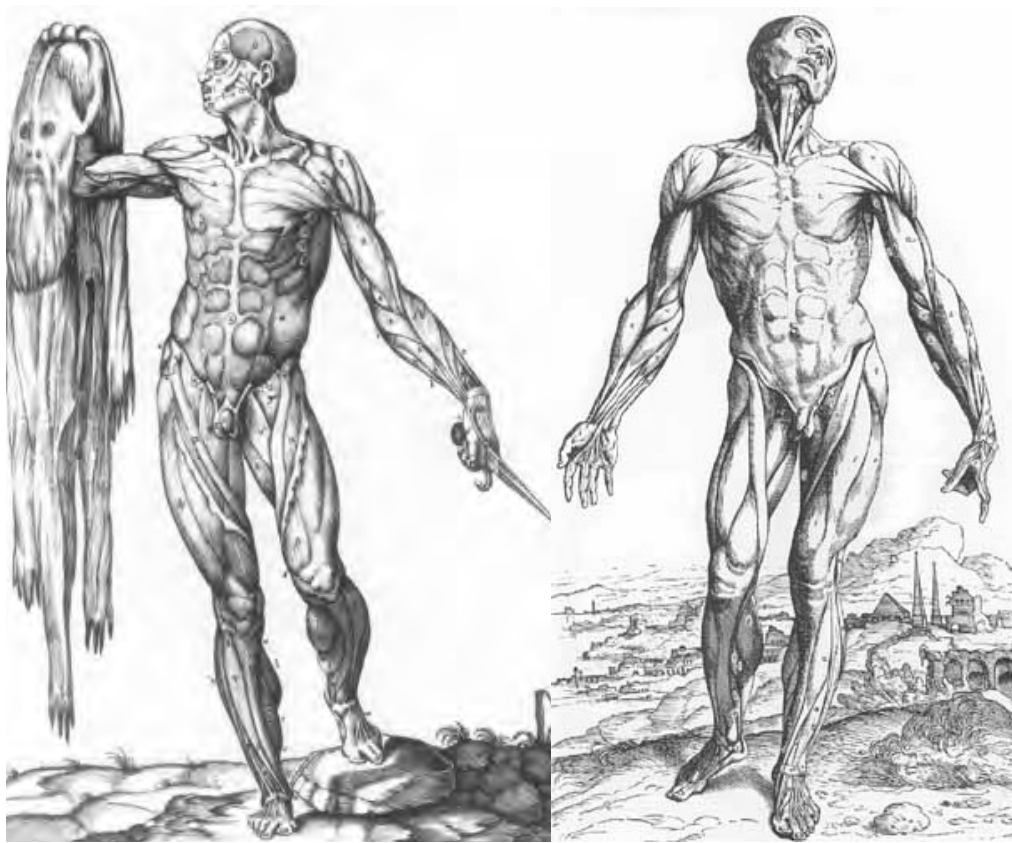

O sistema muscular é formado pelo conjunto de músculos do nosso corpo. Existem cerca de 600 músculos no corpo humano; juntos eles representam de 40 a 50\% do peso total de uma pessoa. Os músculos são capazes de se contrair e de se relaxar, gerando movimentos que nos permitem andar, correr, saltar, nadar, escrever, impulsionar o alimento ao longo do tubo digestório, promover a circulação do sangue no organismo, urinar, defecar, piscar os olhos, rir, respirar...

A nossa capacidade de locomoção depende da ação conjunta de ossos, articulações e músculo, sob a regulação do sistema nervoso. No corpo humano, existem músculos grandes, como os da coxa, e músculos pequenos, como certos músculos da face. Eles podem ser arredondados (os orbiculares dos olhos, por exemplo); planos (os do crânio, entre outros); ou fusiformes (como os do braço). Mas, de maneira geral, podemos reconhecer três tipos de músculo no corpo humano:

- Músculo não estriado (músculo liso): Os músculos não estriados têm contração lenta e involuntária, isto é, os movimentos por eles gerados ocorrem independentemente da nossa vontade;

- Músculo estriado esquelético: Os músculos estriados esqueléticos fixam-se aos ossos geralmente por meio de cordões fibrosos, chamados tendões. Possuem contração vigorosa e voluntária, isto é, seus movimentos obedecem a nossa vontade;

- Músculo estriado cardíaco: O músculo estriado cardíaco é o miocárdio, o músculo do coração, que promove os batimentos cardíacos. Sua contração é vigorosa e involuntária. 
Uma das principais propriedades dos músculos é a capacidade de se contrair; a contratilidade; é ela que torna possíveis os movimentos.

No caso dos músculos estriados esqueléticos, os ossos atuam como alavancas e permitem a efetivação do movimento. Às vezes, o movimento é possível graças ao trabalho antagônico de dois músculos. Por exemplo: quando você dobra um braço, o bíceps braquial se contrai (contração concêntrica), diminui no comprimento e aumenta na espessura. Ao mesmo tempo, o tríceps

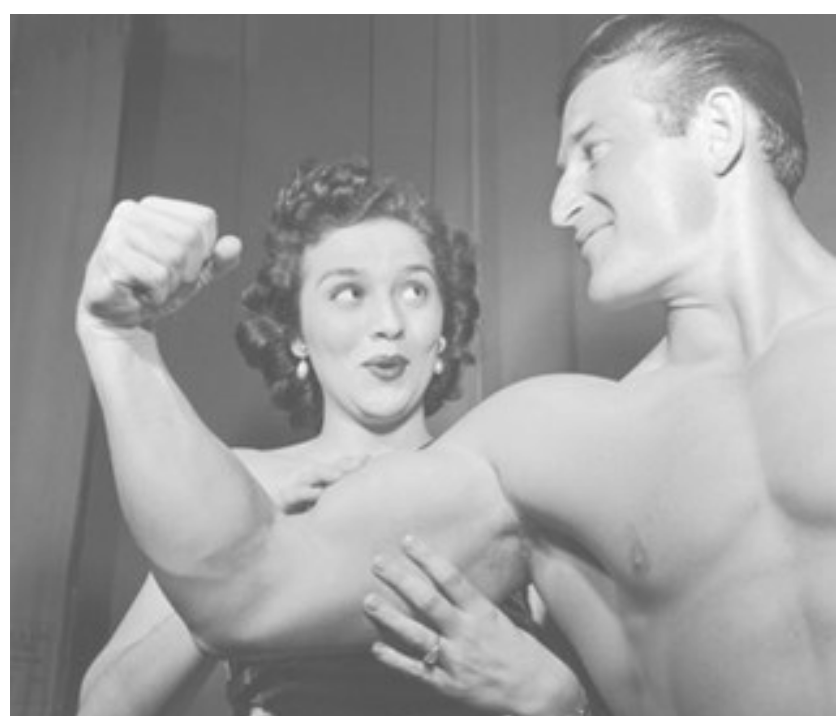
braquial relaxa (contração excêntrica). Ao esticar o braço, a situação se inverte: o bíceps braquial relaxa (contração excêntrica), voltando ao tamanho normal, e o tríceps braquial se contrai (contração concêntrica).

A maior e mais freqüente fonte de força gerada dentro do corpo humano é pela contração dos músculos. Forças passivas adicionais ocorrem pela tensão das fáscias, ligamentos e estruturas não contráteis dos músculos. Uma contração é uma atividade muscular que causa a mudança na relação entre os segmentos das fibras musculares dentro do próprio músculo, podendo ou não levar a um movimento dos ossos nos quais os músculos estão inseridos. Existem três tipos de contrações musculares:

- Concêntrica: um encurtamento do músculo durante a contração é chamado uma contração concêntrica (dinâmica positiva) ou de encurtamento. Exemplos seriam os músculos quadríceps quando um indivíduo está se levantando de uma cadeira ou os flexores do cotovelo quando um indivíduo está levando um copo até a boca. Nas contrações concêntricas a origem e a inserção se aproximam produzindo a aceleração de segmentos do corpo, ou seja, acelera o movimento;

- Excêntrica: Quando um músculo alonga-se durante a contração, esta é chamada uma contração excêntrica (dinâmica negativa) ou de alongamento. Exemplo seriam o quadríceps quando o corpo está sendo abaixado para sentar-se e os flexores do cotovelo quando o copo é abaixado até a mesa. Nas contrações excêntricas a origem e inserção se afastam produzindo a desaceleração do segmentos do corpo e fornecem absorção de choque (amortecimento) quando aterrissando de um salto ou ao andar, ou seja, freia o movimento; 
- $\quad$ Isométrica: Quando um músculo se contrai e produz força sem alteração macroscópica no ângulo da articulação, a contração é dita isométrica. As contrações isométricas são muitas vezes chamadas de contrações estáticas ou de sustentação, normalmente são usadas para manutenção da postura. Funcionalmente estas contrações estabilizam articulações. Por exemplo, para alcançar à frente com a mão, a escápula precisa ser estabilizada de encontro ao tórax.

\section{O PENSAMENTO MUSCULAR}

Tenho uma lemoranca muito boa da orimeira exceriencia com o sistema muscular. Ao me concentrax na cor vermelha, no calor, nas camadas e nas contracões, fui levada a dancar de uma forma incrivelmente livre e viva. Os músculos nos dão a nossa forma, nossa avarôncia, e sua exuressã também é de mostrar a si mesmo, exibir-se. Em sala de aula muitas vezes utilizo músicas dos anos 80 , vrincivalmente, Tina Turner e cindy Lauver, que facilitam o embarque nessa diversã e diminuem a aça do Julgamento sobre si vróprio.

De acordo com o método, o estado mental dos músculos se relaciona com as qualidades de vitalidade, intenção, ação, resistência e cooperação. Segundo Hartley, “O movimento e a dor são os dois primeiros modos pelos quais sentimos e localizamos os nossos músculos; a sensação é um modo mais sofisticado e direto de percebê-los, porém menos conhecido. Geralmente sentimos os nossos músculos em ação de um modo menos consciente, através de uma combinação do sistema muscular e da circulação dos fluídos. Os músculos são muito ricos em sangue e o contato com eles, através das nossas mãos, nos traz essa qualidade de peso, plenitude e fluidez. Os movimentos iniciados originalmente nos músculos esqueléticos (nem todos os movimentos, no sentido pelo qual o BMC® define como o começo do movimento), com a mente focada neles e com o suporte dos fluidos, eles expressarão o fluxo ritmado e a densidade do sangue, assim como a vitalidade, força e atividade dos próprios músculos. A qualidade de pensamento dos músculos é viva, alerta, expressiva e pronta para interagir. Quando os músculos se combinam com o sistema nervoso, este último, contribui com uma qualidade de organização complexa, de ordem, de lógica, de prática realista, para o pensamento do sistema muscular Você pode já ter experimentado essas qualidades quando tentou seguir e compreender o funcionamento dos músculos que acabo de descrever. Se esse pensamento sinta-se claro, difícil, rígido e dogmático, poderoso ou frustrante, dependerá da sua relação com seu próprio sistema muscular e das combinações com os sitemas que tende a expressar. A combinação dos músculos com o sistema nervoso será sentida muito diferente da combinação deles com fluídos, ossos ou órgãos, por exemplo. Os músculos precisam ser sentidos em ação”. (HARTLEY, 1995, p. 174, 175) 


\section{ALGUNS PRINCÍPIOS DO BMC®}

Amassar músculos

Princípio em que os músculos são diferenciados dos ossos, relaxando a coesão fascial desnecessária e aumentando a circulação e vitalidade dos músculos.

\section{Correntes Musculares}

"Na visão do Body Mind Centering ${ }^{\circledR}$, as contrações das fibras musculares podem acontecer aleatoriamente, mas para ser mais eficiente elas devem seguir uma corrente sequencial que vai do fim de um músculo a outro. Essa ação sequencial ocorre rapidamente e quase simultaneamente, mas sentí-la dentro de cada músculo faz grande diferença nas suas qualidades de relaxamanto e atividade. Bonnie Bainbridge Cohen propõe que existe uma corrente direcional ideal de cada músculo, e que ela não muda e é independente da ação. (...) A organização clara dessas correntes dá ao movimento força, facilidade, graça e articulações harmoniosas". (HARTLEY, 1995, p. 166 e 167)

Músculos A - corrente em direção ao centro do corpo (umbigo e L4). São, normalmente, os músculos pequenos e profundos de um grupo muscular. Iniciam movimentos distais e controlam primeiramente os movimentos que requerem articulação precisa. Geram qualidade de iniciação ativa, envolvida e controlada quando a corrente flui em direção ao centro. Caso essa corrente corra em direção oposta, pode manifestar qualidades de fraqueza, perda de interesse e desmotivação;

Músculos B - durante o movimento eficiente, seguem para fora do centro do corpo (umbigo e L4) em direção à perifiria. São normalmente músculos mais largos e superficiais de um grupo muscular. Iniciam movimenos proximais e são o controle primário dos movimentos que requerem força e integração de mais de uma parte do corpo. Os músculos B geram qualidade de substância e força quando seguem em direção à periferia. Caso sigam em direção oposta podem manifestar qualidades de tensão e sensação de excesso de esforço. 
Primeiramente, utilizei meu oróprio toque para entrar em contato com a musculatura. Tentei diferenciar músculos e ossos; sentir a elasticidade, o peso, mobilidade através de massagens, rolamentos, elevações, comoressões, etc.

Coloco Iivremente a atençố nas ações musculares: contraçôes concêntricas, ercêntricas e isométricas. Deiro as sensaçồs dessas ações guiarem a imorovisação.

Aos poucos direciono meu persamento aos pequenos müsculos profundos, localizados perto dos ossos. Músculos de corrente A que correm da Deriferia para o centro.

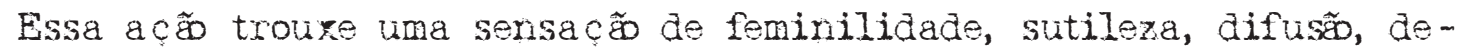
Iicadeza. De repente estava Iimpando a casa; varrendo, passando o pano, dançando... Germinava a cena da dona-de-casa trabalhando.

Sentia-me à vontade no ambiente ficticio - casa. Poderia me mover Iivre e, ao mesmo temoo, controladamente. Ara vivia vivamente em casa como se ela fosse acolchoada.
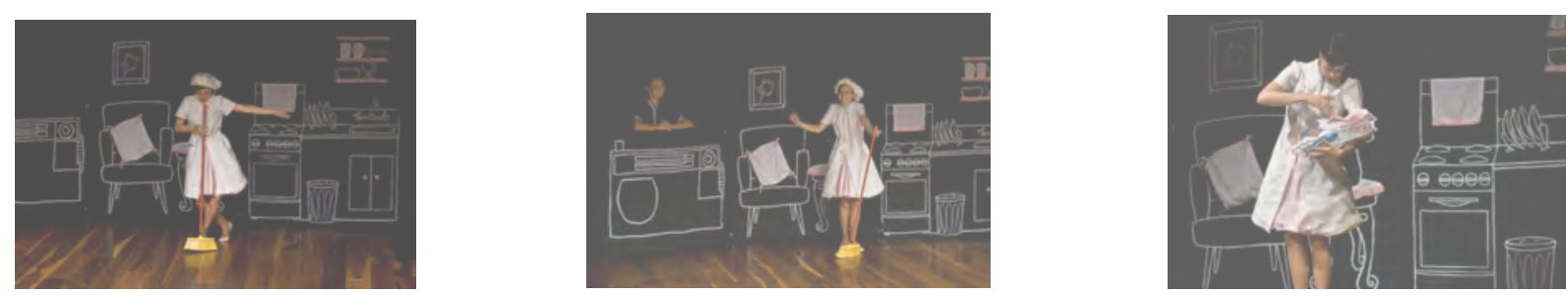

A musculatura $B$ que corre do centro para as periferias troure preciño e dilataç̃̃ das ações de Ana, tornando-a mais agil, segura, graciosa e firme.

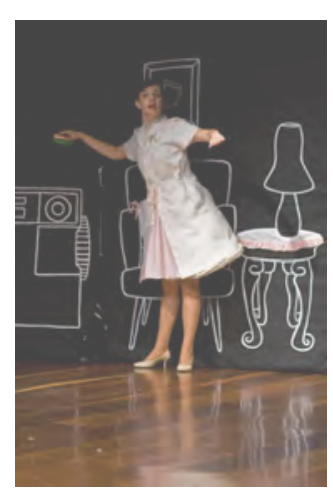




\section{MATRIZES MUSCULARES}

As experiências com o sistema muscular contribuíram com a vida e forma de Ana e de seu ambiente. Aqui surgiu a força da fragilidade óssea. Os movimentos da personagem em casa variaram de acordo com as correntes musculares em foco. A corrente A desenhou ações de trazer o espaço para perto e pediu o trabalho com objetos: vassoura, pano, escova, etc. A corrente B criou ações para o espaço, de lançamento, velocidade e agilidade.

Ana ganhou a possibilidade de se movimentar sem medo ou receio de se quebrar, pois construiu a musculatura a sua volta, seu espaço macio, vivo, pulsante. Ela se tornou rainha e comandante do lar. Diferentemente de criar pontos ou tridimensionalizá-los, a musculatura direcionou e "embelezou" os movimentos (de fora para dentro ou de dentro para fora).

Posso dizer que o estado muscular organizou e "estofou” o espaço do corpo (Ana e o lar). Esse sistema revelou a existência do duplo feminino/ masculino em Ana; Gueixa (musculatura A) e Samurai (musculatura

"(..) as acõos dos braços e das mãos devem, semore, estar conectados com a coluna B) vertebral e com o koshi. ( ...) Ao contrário do samurai, que trabalha em bloco $\theta$ B). com o veso, a gueira trabalha a manioulaça e a dinamizaç̃ da energia vor meio da

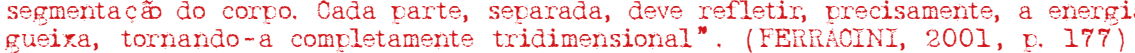

Artaud, através da respiração, elenca os esforços musculares em femininos e masculinos, como podemos verifivar nessa passagem, "Deve-se observar que tu-

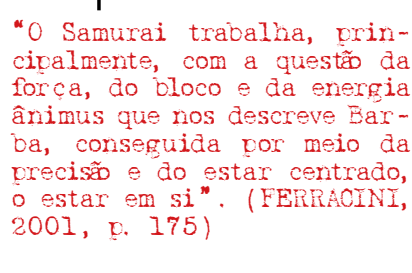
do o que é feminino, o que é abandono, angústia, apelo, invocação, o que tende para alguma coisa num gesto de súplica, baseia-se também nos pontos de esforço, mas como um mergulhador palmilha o fundo do mar para depois voltar à superfície: há como que um jato de vazio no lugar onde estava a tensão. Mas nesse caso o masculino volta para povoar o lugar do feminino como uma sombra; enquanto o estado afetivo é masculino, o corpo interior compõe uma espécie de geometria inversa, uma imagem do estado invertido”. (ARTAUD, 1999, p. 158) As respirações masculinas e femininas se complementam nos seus próprios esforços inversos, e suas combinações são capazes de penetrar nos sentimentos. Assim, ele complementa, “Tomar consciência da obsessão física, dos músculos tocados pela afetividade, equivale, como no jogo das respirações, a desencadear essa afetividade potencial, a lhe dar uma amplitude surda mas profunda, e de uma violência incomum”. (ARTAUD, 1999, p. 158) 


\subsubsection{IMPRESSÕES ENDÓCRINAS}

"Este é o sistema da quietude interna, de ondas ou explosões de caos/equilíbrio, e da cristalização da energia em experiências arquetípicas. As glândulas endócrinas motivam a intuição e a percepção e a compreensão do Pensmento Universal”. (COHEN, B. B., 2008, p. 3)

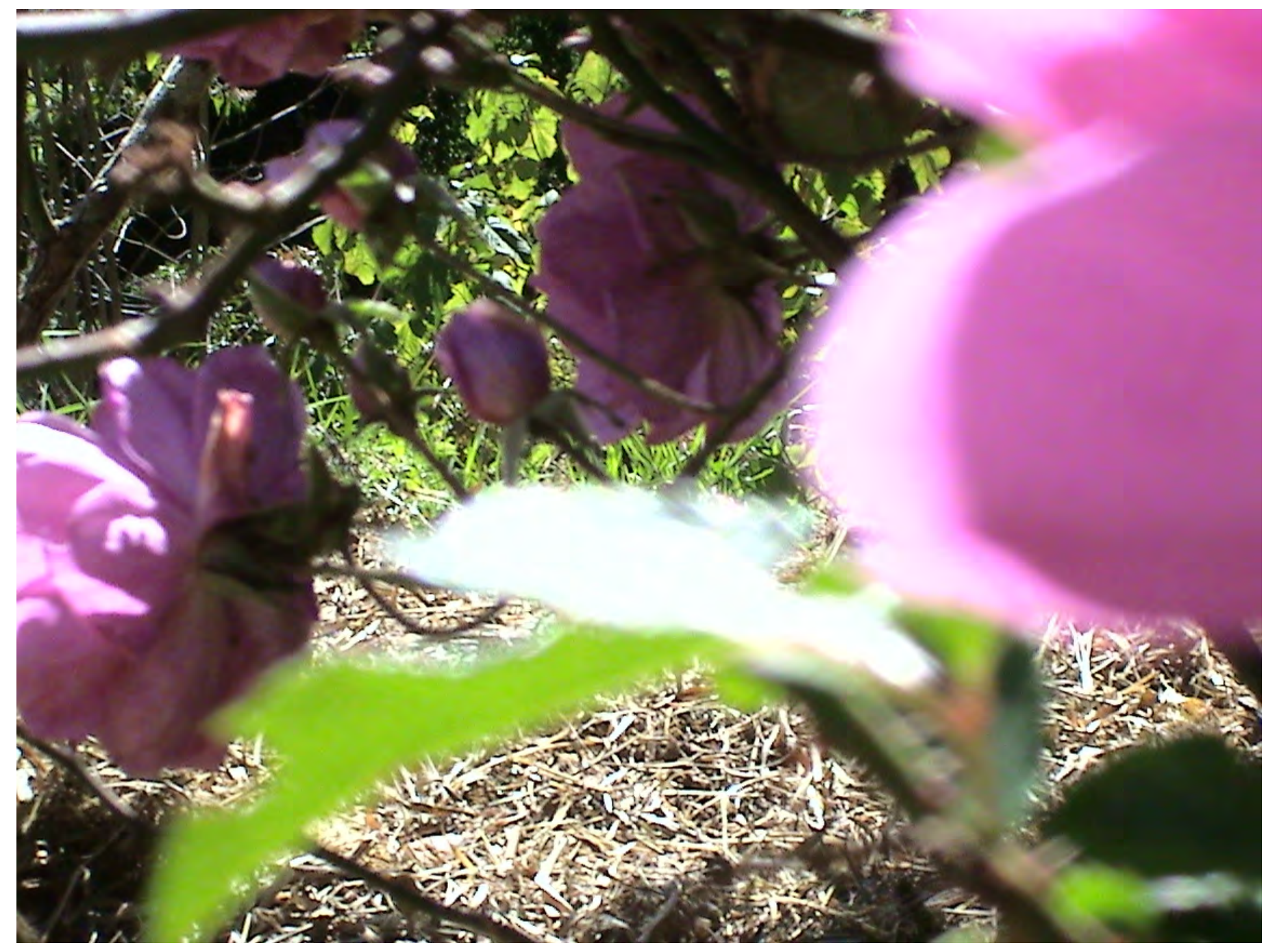




\section{PENSAMENTO ENDÓCRINO}

“O sistema endócrino se relaciona com a intuição, sentimento e equilíbrio ou caos interno. Ele toca profundamente o centro de quem nós somos e como nos percebemos e nos expressamos no mundo. Questões relativas às dimensões pessoais, sociais, criativas e espirituais são expressas através das diferentes glândulas.

O trabalho com as glândulas através do movimento livre e de exercícios especificos nos ajuda equilibrar o sistema endócrino como um todo. (...) As glândulas endócrinas são fonte de energia criativa e, ao nos conectarmos com elas acessamos movimentos e imagens escondidos nas camadas de nosso ser. Enquanto cada glândula expressa seu pensamento, sentimento e movimento, eles parecem arquetípicos e universais, diferentes culturas e indivíduos descobrem imagens e formas únicas que convergem para as mesmas qualidades. Essa tendência que é ao memso tempo profundamente pessoal e universal, significa que o sistema endócrino é um importante veículo para a comunicação das nossas mais profundas intuições pessoais de maneiras criativas que podem ser reconhecidas e compartilhadas com os outros”. (HARTLEY, 1995, p. 212)

Para mim, a experiência endócrina nos leva à dimensão do invisível, das cores e da amplitude. No BMC®, cada glândula se conecta energeticamente a um osso ou articulação específica e dá apoio para a coluna. Elas também governam órgãos particulares expressando diversas qualidades de pensamento e sentimento como os próprio órgãos. Entretanto sua energia é menos densa.

Podemos, também, relacioná-las aos chakras. Elas agem, ligando a energia invisível e a manifestação do corpo físico.

\section{SISTEMA ENDÓCRINO}

O sistema endócrino é formado pelo conjunto de glândulas endócrinas, as quais são responsáveis pela secreção de substância denominadas hormônios. As glândulas endócrinas (do grego endos, dentro, e krynos, secreção) são assim chamadas por que lançam sua secreção (hormônios) diretamente no sangue, por onde 
eles atingem todas as células do corpo. Cada hormônio atua apenas sobre alguns tipos de células, denominadas células-alvo.

As células alvo de determinado hormônio possuem, na membrana ou no citoplasma, proteínas denominadas receptores hormonais, capazes de se combinar especificamente com as moléculas do hormônio. É somente quando a combinação correta ocorre que as células-alvo exibem as respostas características da ação hormonal.

A espécie humana possui diversas glândulas endócrinas, algumas delas responsáveis pela produção de mais de um tipo de hormônio. Entretanto Cohen, B. B. reorganiza a classificação das glândulas endócrinas e adiciona à lista algumas estruturas que possuem atividades de regulação da respiração e circulação, e controle do nível de certos minerais no sangue. Essas estruturas são denominadas "corpos", distinguindo-as das formalmente reconhecidas glândulas. Os “corpos” são incluídos no sistema endócrino, pois se expressam energeticamente como glândulas, formando, juntos, um sistema de canais energéticos onde o movimento flui através da coluna com uma qualidade particular de claridade e prontidão.

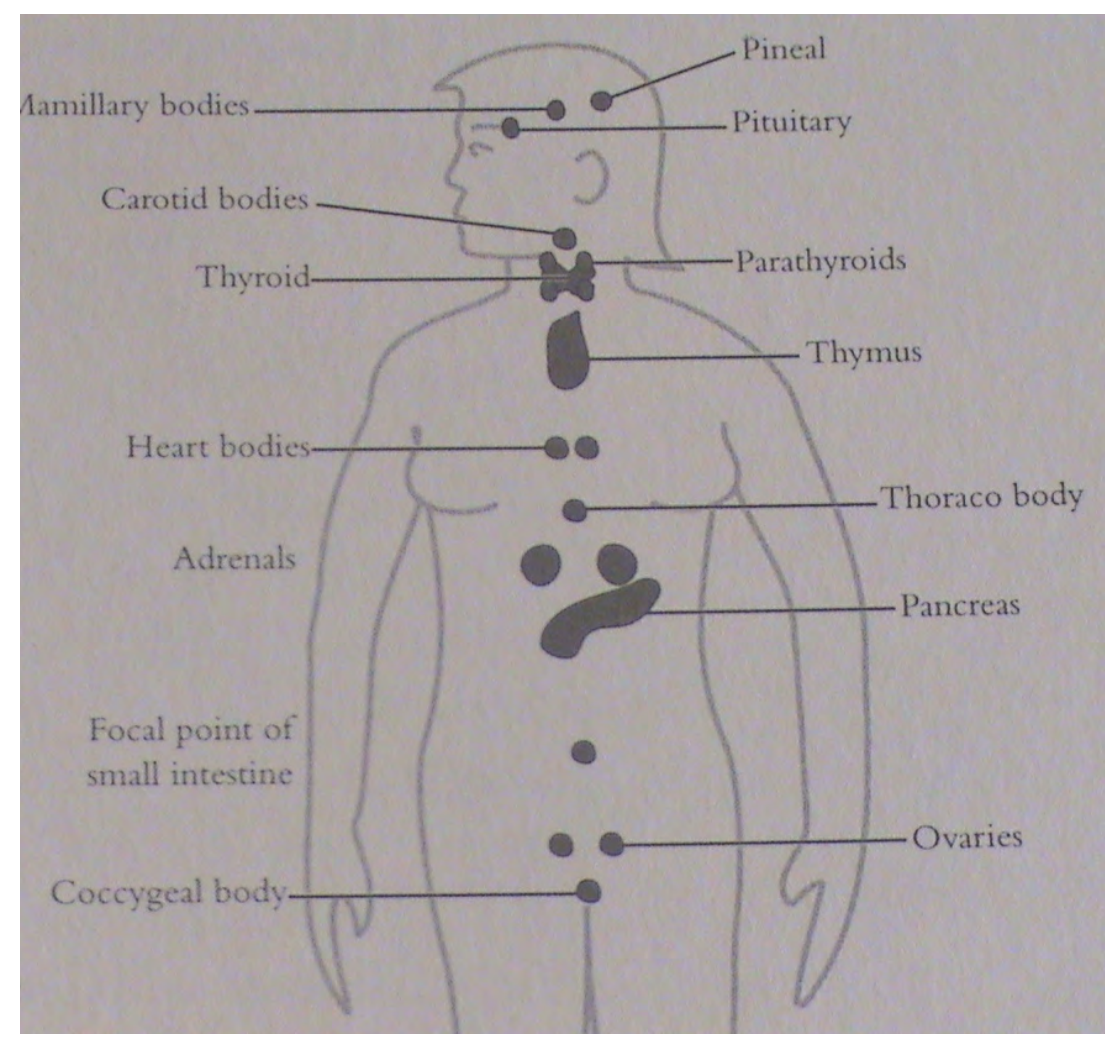




\section{ALGUNS PRINCÍPIOS DO BMC®}

Os mesmos princípios para se trabalhar com os órgãos podem ser aplicados com o trabalho com as glândulas:

- $\quad$ Estudo sobre forma, localização e estrutura;

- Respirar nas glândulas;

- $\quad$ Soar nas glândulas - encontrar o ritmo, tom e vibração de cada uma;

- $\quad$ Expirar em "S" ou sibilar nas glândulas;

- Inicia movimento através das glândulas.

É importante não trabalhar uma glândula isoladamente, pois elas são pontos energéticos extremamente sensíveis, que muito ou pouco estimulados criam instabilidade em todo o organismo. Deve-se trabalhar o sistema como um todo, abrindo seus canais no tempo necessário para cada pessoa.

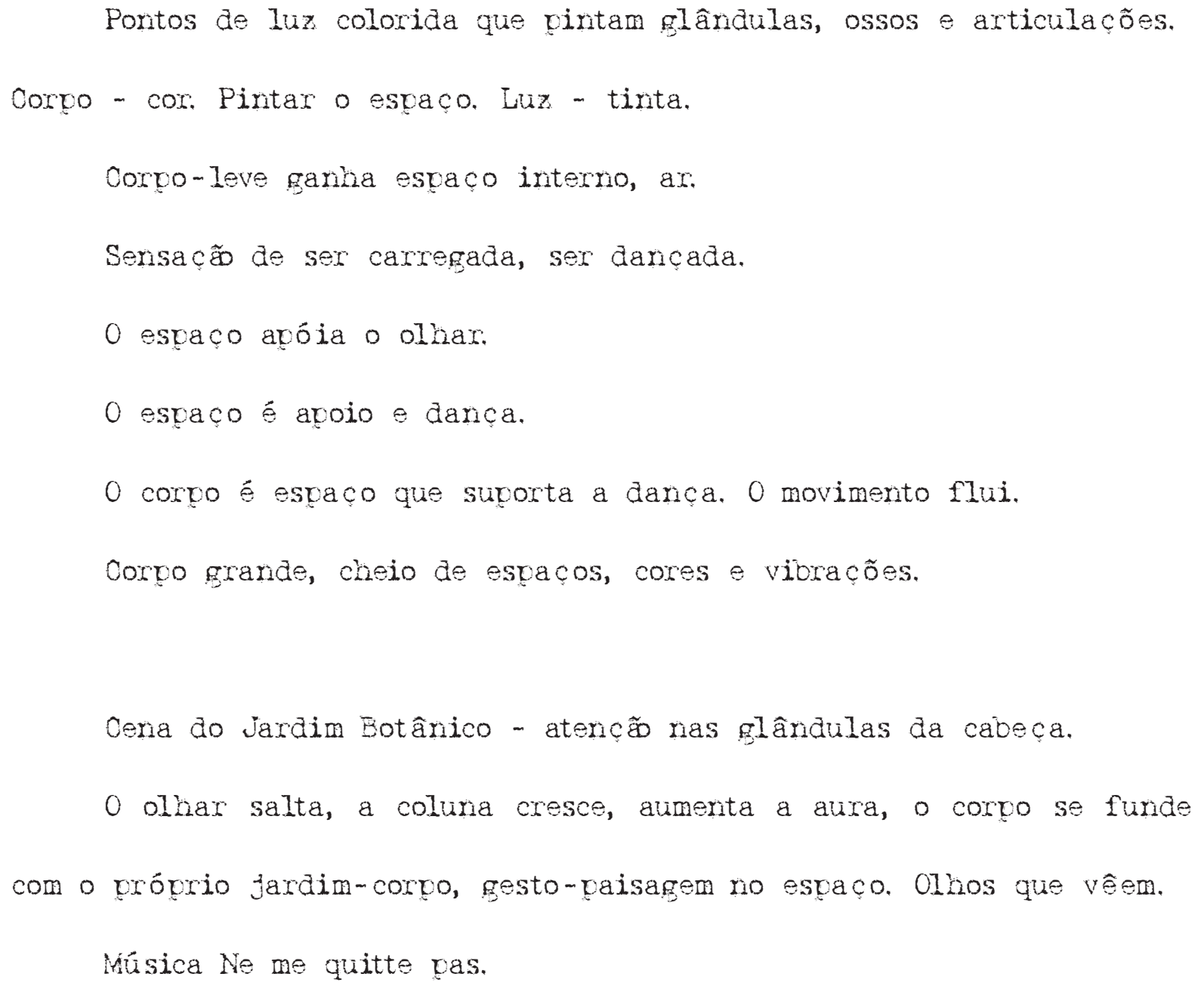




\section{MATRIZES ENDÓCRINAS}

A sensação de amplitude originária do sistema endócrino contaminou todos os sistemas. Acredito que a resultante principal foi o próprio corpo dilatado alinhado energerticamente com o espaço. Energia glandular, cristalina e colorida do espaço do corpo.

Os olhos sofreram, também, grande modificação. Eles foram apoiados pelo espaço e se comportaram como uma extremidade que quer o espaço, que vai até ele e impulsiona o corpo. Punctums cristalinos na cabeça que fazem o olhar saltar, querer, desejar.

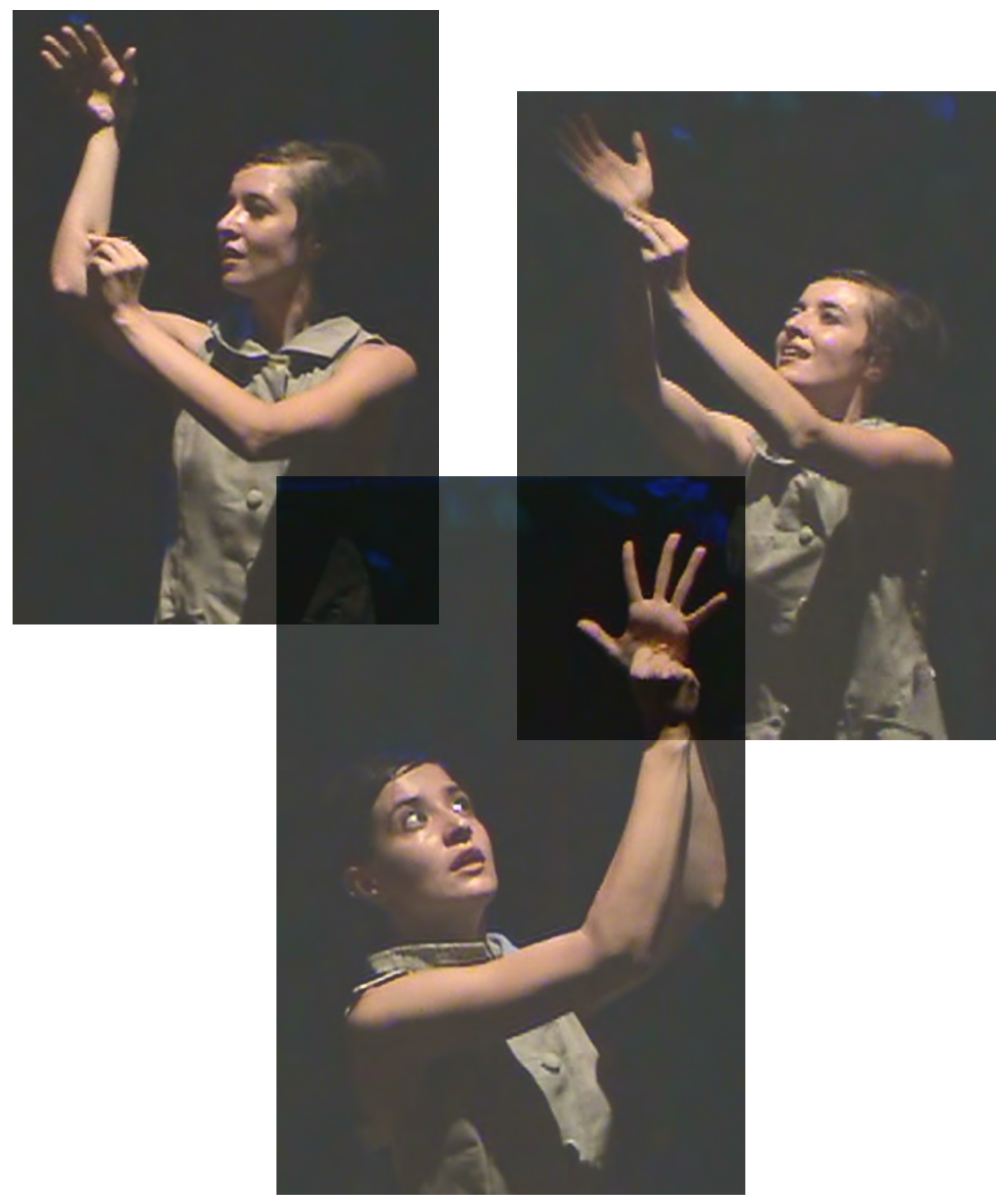




\section{DICIONÁRIO DE POTENCIALIDADES EXPRESSIVAS}

"O atlas corporal do ator é, pois, constituído, fundamentalmente, de energia". (Mariz, 2007, p. 211)

A partir dos jogos entre percepções e ações sistêmicas, músicas, imagens, situações ficcionais e sugestões simbólicas pude extrair matrizes corporais e codificar seus impulsos criadores. Este conjunto de caminhos possibilitadores compõe o que o professor Armando Sérgio da Silva chama de Dicionário de Potencialidades Expressivas; Ou, para dialogar com José Gil, uma espécie de cartografia do espaço do corpo.

Desta forma, a identificação de punctums permitiu a cartografia de espaços, vetores, pontos, volumes e tempos. Ou seja, localizei pontos de energia que fluem e se ligam, desejando-se. Intensifiquei suas qualidades, atualizando memórias ósseas, orgânicas, musculares e endócrinas. Os pontos percebidos e intensificados agenciaram o espaço corpo, prolongando-o.

A organização pessoal desse material carrega, também, em si o tempo, o espaço e o humor de cada improvisação. Portanto ela deve ser percebida como "uma" das infinitas possibilidades que o cruzamento das experiências pode oferecer.

Para facilitar a visualização desse processo, esquematizei as resultantes da seguinte maneira:

\begin{tabular}{|c|c|c|c|}
\hline SISTEMAS & PUNCTUMS & MATRIZES & ESPAÇO / TEMPO \\
\hline Ósseo & $\begin{array}{l}\text { Pontos: Terceiro dedo (mãos e pés); } \\
\text { articulação coxo-femural e escapulo- } \\
\text { umeral; Mãos, escápulas e costelas } \\
\text { Vetores: Todos os pontos apontam para } \\
\text { o centro do corpo, fechando-o. }\end{array}$ & $\begin{array}{c}\text { Postura } \\
\text { Gestos } \\
\text { "Jardim Botânico" }\end{array}$ & $\begin{array}{l}\text { Claridade } \\
\text { Linhas } \\
\text { Estrutura }\end{array}$ \\
\hline Orgânico & $\begin{array}{l}\text { Volumes: Coração, Boca, Pulmões } \\
\text { Vetores: Opostos e espiralados }\end{array}$ & \begin{tabular}{|c|} 
Modulação da postura \\
"Olhar o cego" \\
Boca-desejo \\
Olhar vago (ar)
\end{tabular} & $\begin{array}{c}\text { Espiral } \\
\text { Densidade } \\
\text { Tridimensionalidade } \\
\text { Conflito }\end{array}$ \\
\hline Muscular & $\begin{array}{l}\text { Pontos: Músculos pequenos e perto } \\
\text { dos ossos (A); músculos grandes e su- } \\
\text { perficiais (B) } \\
\text { Vetores: Músculos A das periferias } \\
\text { para o centro; Músculos B do centro } \\
\text { para as periferias. }\end{array}$ & "Limpar a casa" & $\begin{array}{c}\text { Beleza } \\
\text { Suavidade } \\
\text { Força } \\
\text { Precisão } \\
\text { Feminino e Masculino. }\end{array}$ \\
\hline Endócrino & $\begin{array}{l}\text { Pontos: Glândulas da cabeça e Olhos } \\
\text { Vetores: Pequenas flechas para fora e } \\
\text { para dentro da pele }\end{array}$ & $\begin{array}{l}\text { Olhos-desejo } \\
\text { "Jardim Botânico" }\end{array}$ & $\begin{array}{l}\text { Amplitude } \\
\text { Dilatação } \\
\text { Quietude }\end{array}$ \\
\hline
\end{tabular}


Percebi, então, que cada experiência sistêmica gera diferentes estados corporais ou ações físicas no espaço passíveis de serem (re)criados em cena. Para isso, organizei portas de entrada (punctums), simultaneamente fixos - localização concreta no corpo - e maleáveis - pois suas formas de expressão dependem do jogo, muitas vezes inconsciente, de estabilidade/mobilidade com outros sistemas.

Segundo a metodologia da Oficina da Essência do professor Armando Sérgio da Silva, esse "dicionário pessoal” antecede a fase de composição de signos teatrais. E, nesse sentido, mais uma vez percebemos a influencia da performance na preparação cênica, pois tal como o performer, buscamos a criação de um vocabulário e uma linguagem próprios. De acordo com Renato Cohen, “Na passagem para a expressão artística performance, uma modificação importante vai acontecer: o trabalho passa a ser muito mais individual. É a expressão de um artista que verticaliza todo seu processo, dando sua leitura de mundo, e a partir daí criando seu texto (no sentido sígnico), seu roteiro e sua forma de atuação. O performer vai se assemelhar ao artista plástico, que cria sozinho sua obra se arte; ao romancista, que escreve seu romance; ao músico, que compõe sua música.”. (1989, p. 100)

Logo, a partir daqui tinha que criar minha própria dramaturgia, pois verifiquei a possibilidade da (re) criação das matrizes em cena ou ensaio. E, como vimos, a preparação é a fase que antecede o nascimento - a única etapa - a apresentação junto ao público. 


\subsection{COMPOSIÇÃO DE SIGNOS}

"O ator, ao compor seu personagem, constrói, na verdade, um "sistema de símbolos que demonstra o que está por trás da mascara da visão comum: a dialética do comportamento humano”. (MARIZ, 2007, p. 109)

Configurar esteticamente as matrizes anteriormente vivenciadas em laboratório, essa é a ação desta fase. Para realizar esta tarefa contei com a participação das atrizes Isis Madi e Sandra Pestana, além do constante diálogo e observação dos membros do CEPECA, que acompanharam constantemente o processo, desde as primeiras formulações e problematizações.

Dúvidas e insegurança perante tantas possibilidades, esse é o sentimento desta fase. E, juntamente com as atrizes experimentei caminhos diversos a procura de uma linguagem. É muito interessante e curioso pensar sobre os passos dados, os tropeços e tombos levados, as soluções encontradas, esquecidas e relembradas... Como foi difícil caminhar pela trilha mais simples... E como foi incrível nossa capacidade de não seguir o curso natural das coisas...

Naturalmente, estruturarímos as matrizes de acordo com a história, e nosso storyboard ficaria desta maneira:

\begin{tabular}{|c|c|c|c|}
\hline ANA EM CASA & ANA NO BONDE & ANA NO JARDIM & ANA EM CASA \\
\hline \multirow[t]{2}{*}{ S. MUSCULAR } & S. ORGÂNICO & S. ENDÓCRINO E & (?) \\
\hline & & ÓSSEO & \\
\hline LIMPAR A CASA & VER O CEGO & VER E SER O JARDIM & PREPARAR O \\
\hline
\end{tabular}

Mas, assim ficaria muito simples... Então sem nenhum motivo aparente, sem querer, conduzidas por um fluxo livre de idéias passamos por recursos multimídia, projeções no corpo, no espaço e no público; pela história de três Anas vizinhas (Ana-de-casa, Ana-executiva e Ana-artista); pela criação de um gato infame filosófico, um personagem que provocaria os pensamentos de Ana; pela invasão de narradoras de patins; e acredite ou não, pela participação de Roger Rabit e Darth Vader numa cena onde Ana mataria o famigerado gato! 
Felizmente contávamos com os olhares atentos e com os ouvidos generosos dos colegas, que escutavam todas as idéias mirabolantes e os lamentos das incertezas. Até que um amigo perguntou: "Porque duas narradoras não contam a história de uma dona-de-casa que um dia vê um cego?”. E entendemos que menos é mais!

Assim, detalhei as matrizes, dilatando-as ou comprimindo-as, e criei outras como "o jantar". Para visualizar melhor esse processo, descreverei apenas a ampliação e transformação da matriz "ver o cego" e a criação da matriz "o jantar".

Retornei ao conto:

“A rede de tricô era áspera entre os dedos, não íntima como quando a tricotara. A rede perdera o sentido e estar num bonde era um fio partido; não sabia o que fazer com as compras no colo. E como uma estranha música, o mundo recomeçava ao seu redor. O mal estava feito. Por quê? teria esquecido de que havia cegos? A piedade a sufocava, Ana respirava pesadamente. Mesmo as coisas que existiam antes do acontecimento estavam agora de sobreaviso, tinham um ar mais hostil perecível... O mundo se tornara de novo um mal-estar. Vários anos ruíam, as gemas amarelas escorriam. Expulsa de seus próprios dias, parecia-lhe que as pessoas na rua eram periclitantes, que se mantinham por um mínimo equilíbrio à tona da escuridão - e por um momento a falta de sentido deixava-as tão livres que elas não sabiam para onde ir. Perceber uma ausência de lei foi tão súbito que Ana se agarrou ao banco da frente, como se pudesse cair do bonde, como se as coisas pudessem ser revertidas com a mesma calma com que não o eram. (...) Na calçada, uma mulher deu um empurrão no filho! Dois namorados entrelaçavam os dedos sorrindo... E o cego? Ana caíra numa bondade extremamente dolorosa”. (LISPECTOR, 1998, p. 22)

Procurei o pensamento:

Ana está, passivamente, no bonde. E é afetada pelo mascar chicletes de um cego. A partir desse momento, o que era habitual passa a ganhar materialidade. Ana percebe que a sacola de compras é feita de fios. As compras estão em seu colo. Vê o cego e os passantes da cidade. Percebe a periferia, o espaço ao seu redor. Ela é o umbigo da cena, o centro que está inserido num território de atravessamentos. Percebi a mind do texto através da corporificação das relações entre centro e periferia ou umbigo e extremidades. 


\section{Corporifiquei:}

Foi assim que começaram os ensaios que se seguiram, pelo umbigo. De acordo com a visão do BMC®, a irradiação umbilical é o segundo padrão de movimento que se desenvolve, ainda no útero, e subjaz padrões posteriores durante a evolução da criança. Ele é visto, principalmente, em recém nascidos. É quando o movimento é iniciado pelo umbigo. É um padrão circular com simetria radial como uma estrela do mar. Esse padrão percebe a igualdade entre as seis extremidades - cabeça, cóccix, mãos e pés - tirando o controle da cabeça e deslocando-o para o umbigo, o meio do corpo.

Como nos explica Hartley, convidar a expressão da irradiação umbilical, nos permite reorganizar e integrar o corpo como um todo, despertando reflexos primitivos desenvolvidos durante a evolução do sistema nervoso, coordenados pela coluna ou pelo cérebro primitivo (lower brain). Eles estão relacionados com o equilíbrio e modulação do tônus muscular e coordenação para engatinhar, ficar de pé, andar, etc. A conexão entre as extremidades e o umbigo percorre todo o corpo, alastrando-se pelas células de todos os tecidos, integrando ossos, músculos, ligamentos, órgãos, glândulas, nervos, fluídos e outros. Cada parte do corpo se relaciona particularmente com alguma extremidade. Assim, durante a exploração desse padrão, podemos perceber onde bloqueamos a energia, e como a reorganizamos.

Além disso, a irradialção umbilical estimula a percepção da subjetividade do espaço, ou seja, como um feto que, no útero, recebe e compreende sensações de toque, movimento, ritmo, vibrações de luz, sons e pensamentos; compreendemos que o espaço é vivo e vibrátil capaz de afetar, atravessar e apoiar as emoções do corpo.

O pensamento desse padrão permite a experiência da fronteira do corpo e do espaço; da fluidez arrítmica entre extensões, flexões, expansões, contrações dos membros em conjunto ou separados, descobrindo e dissolvendo o senso de limite. “No pensamento desse padrão podemos brincar por algum tempo no limiar da consciência, onde tudo é possível, mas ainda, não está manifestado”. (HARTLEY, 1995, p. 40)

Para facilitar e ativar conscientemente este padrão elaborei e revisitei alguns exercícios . Entretanto, julgo necessária a primeira fase de respirar e convidar essa expressão, de acordo com o tempo de cada pessoa. Essa fase, nos permite, perceber ansiedades, fragilidades, medos e desejos, pois, muitas vezes, é difícil fazer 
um exercício que nos pede para não fazer nada. E, nisso, observei que o sono pode ser um grande aliado. Percebi, durante workshops ministrados, que dormir tem o poder de deslocar a atenção do pensamento habitual e organizá-lo, focalizando-o na respiração celular ou direcionando-o ao exercício.

Improvisei:

Colocando em relação o pensamento da irradiação umbilical, as matrizes ósseas e orgânicas e a situação ficcional, realizamos a seguinte improvisação:

Estipulei, anteriormente, que cotidianamente o olhar de Ana não se fixa em nada, é vago, sem interesse por nada em especial (olhar sustentado pelo ar da matriz peitoral). Sentada numa cadeira, no meio da sala de ensaio (o umbigo), experimentei esse vazio, essa fluidez do olhar. De repente me peguei com sono, com tônus baixo, sem atitude, inerte. Isso me levou à gordura - um fluído semi-viscoso - derretendo-me e escorrendo o pensamento de Ana.

De acordo com o BMC®, a gordura pode ser explorada em conjunto com o sistema dos fluídos. Ela é estimulada e convidada à expressão através de toque, música, vocalização, entre outros. Ela possui peso, mas não é sólida ou forte. A experiência na gordura é um peso flutuante e poderosamente sensual.

"Hoje podemos olhar para outras culturas para re-aprender como corporificar esse sistema. Por exemplo, as Culturas Africanas aprovam a expressão da gordura como sendo o poder que tem uma qualidade terrena e sensual, enquanto que nas culturas das Ilhas do Pacífico vemos uma expressão deste sistema muito mais ritmada, leve e fluida”. (HARTLEY, 1995, 290)

Deixei-me conduzir por esse estado, dilatando-o. A respiração, aos poucos, ganhava espaço. O sono me levou a abrir a boca em grandes e pequenos bocejos. Meus membros expandiam e recolhiam, espreguiçando-se. A moleza me conduziu ao chão. O tédio tomava conta. Ana se imbuia de inação. Fiquei até enjoada e mal consegui continuar o ensaio. Mas respirei fundo e tentei contrair esse estado.

Sentei novamente e o retomei a ação de olhar. Minhas mãos intuitivamente não paravam, fazendo pequenos gestos já explorados anteriormente.

Localizei o cego numa diagonal atrás, o que me forçava a uma rotação do eixo. O retorno à posição inicial já deveria conter uma mudança. Sem que "pensasse", edifiquei o corpo. Montei nos ossos, duros, 
estruturais e protetores. A matriz “ver o cego” seqüênciou organicamente.

Até aqui, corporifiquei a relação entre umbigo (Ana) e periferias (mundo externo), entretanto, a partir desse momento, as periferias (passantes da cidade) atravessam o centro (Ana) e o desorganizam. Ou seja, tinha o desafio de corporificar cada ação dos passantes sobre Ana e suas próprias percepções-ações.

Inspirada na ação de mascar chiclete, escolhi a boca como fio condutor para a improvisação sobre os agentes-passantes. Encontrei, dessa forma, bocas-desejos corporificadas em um cego que masca chiclete, uma prostituta que ri e debocha, uma mulher que grita e xinga o filho, um casal que se beija. Afinal, também estava impregnada dos simbolismos da boca. De acordo com Miranda, “com sua força capaz de animar, criar, organizar e fazer crescer, a boca também é capaz de destruir, matar, confundir, diminuir e ferir. Nada mais apropriado do que dizer: seu símbolo oscila ao sabor das pessoas e de seus personagens”. (MIRANDA, 2000, p. 220)

Assim, percebi, agi e compus a cena de quando Ana vê o cego. Primeiramente, escolhi o trecho do conto e percebi seu pensamento (relação entre centro e periferia). Encontrei um padrão que lhe dá forma (irradiação umbilical). Ele, por sua vez, foi apoio para a manifestação de outros tecidos (gordura, ossos, órgãos, boca) e pensamentos (languidez, segurança, emotividade e desejo). Em sequência, essas percepções e ações modificaram o continente da cena do Jardim Botânico, elaborada a priori com o pensamento das mãos e dilatada com a energia endócrina.

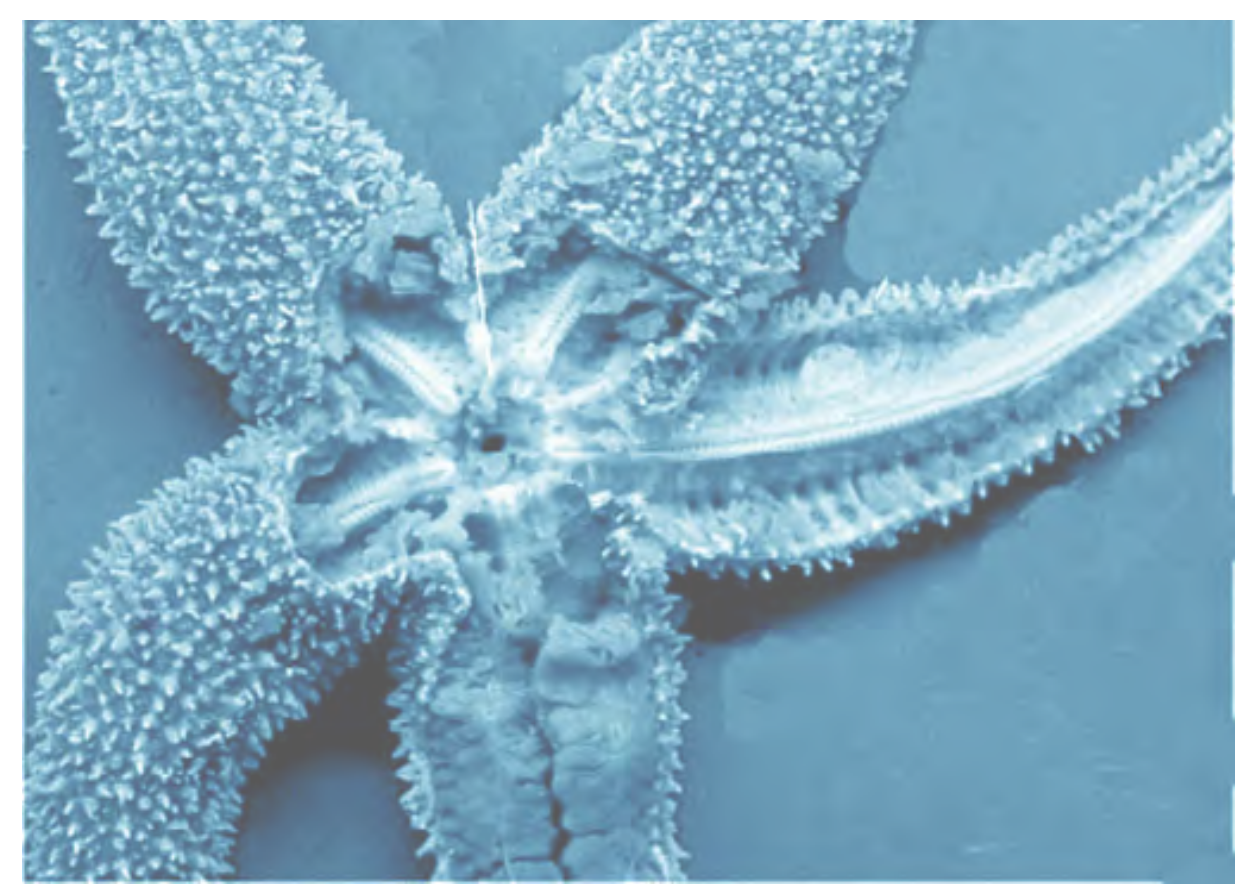


Ao contrário da consciência dessa criação relatada, “o jantar” surgiu de repente, num ensaio desanimado e sem estímulos...

Estava desconcentrada e nada surpreendente acontecia durante as experiências. Queria ir embora antes de pegar trânsito; sair daquele espaço que me obrigava a criar; deixar a angústia de ser expressiva para outro dia! Mas, por algum motivo, insisti, fiquei, coloquei uma música e sentei num banquinho.

Aos poucos a música atravessava minha pele e preenchia o espaço a minha frente e atrás de mim. Era como se eu estivesse entre dois círculos ou duas bolas ou dois sacos. Crescia um espaço uterino, aconchegante, acolhedor... embriológico.

Saco vitelino e saco amniótico, nossos dois suportes embrionários.
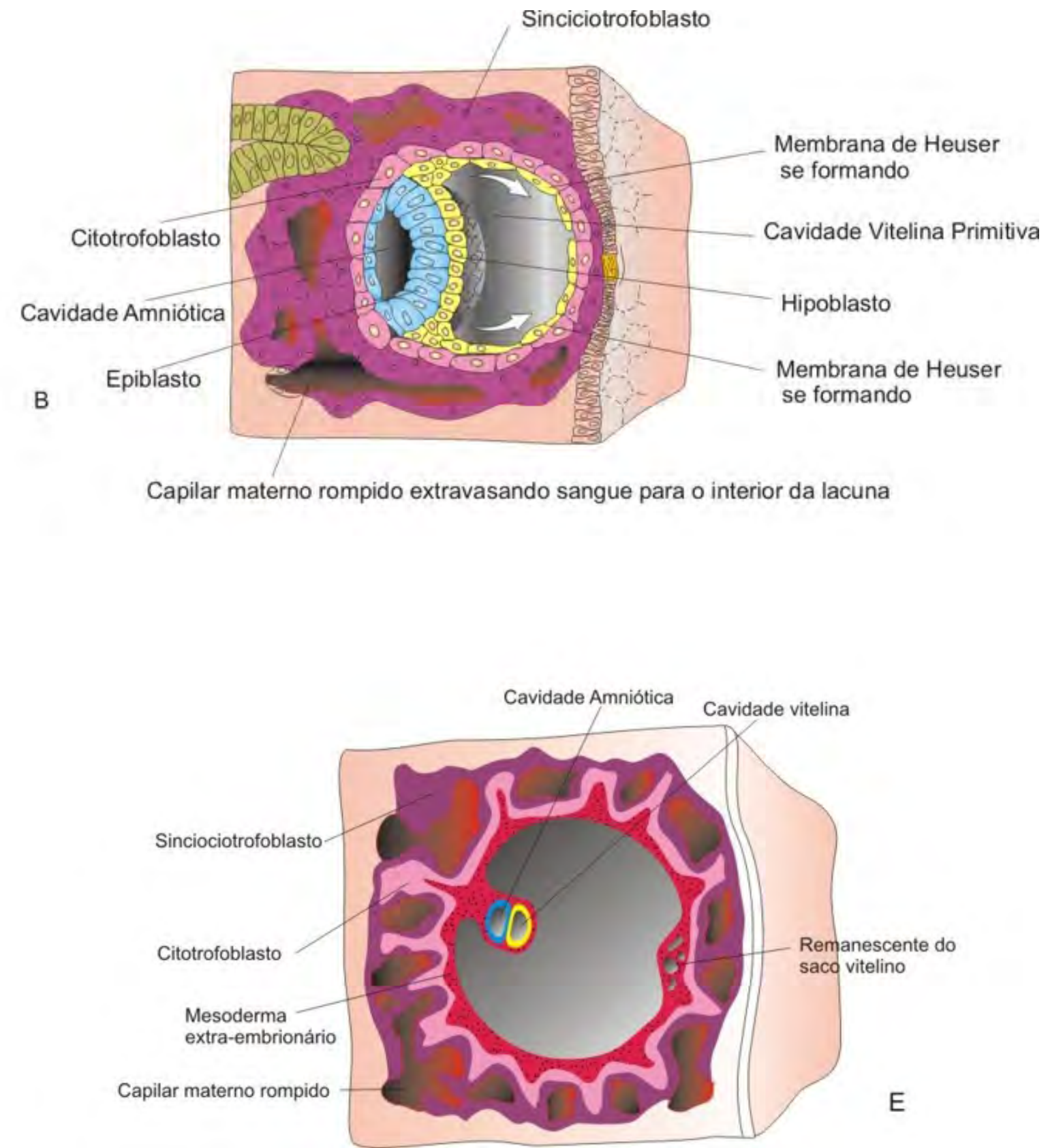

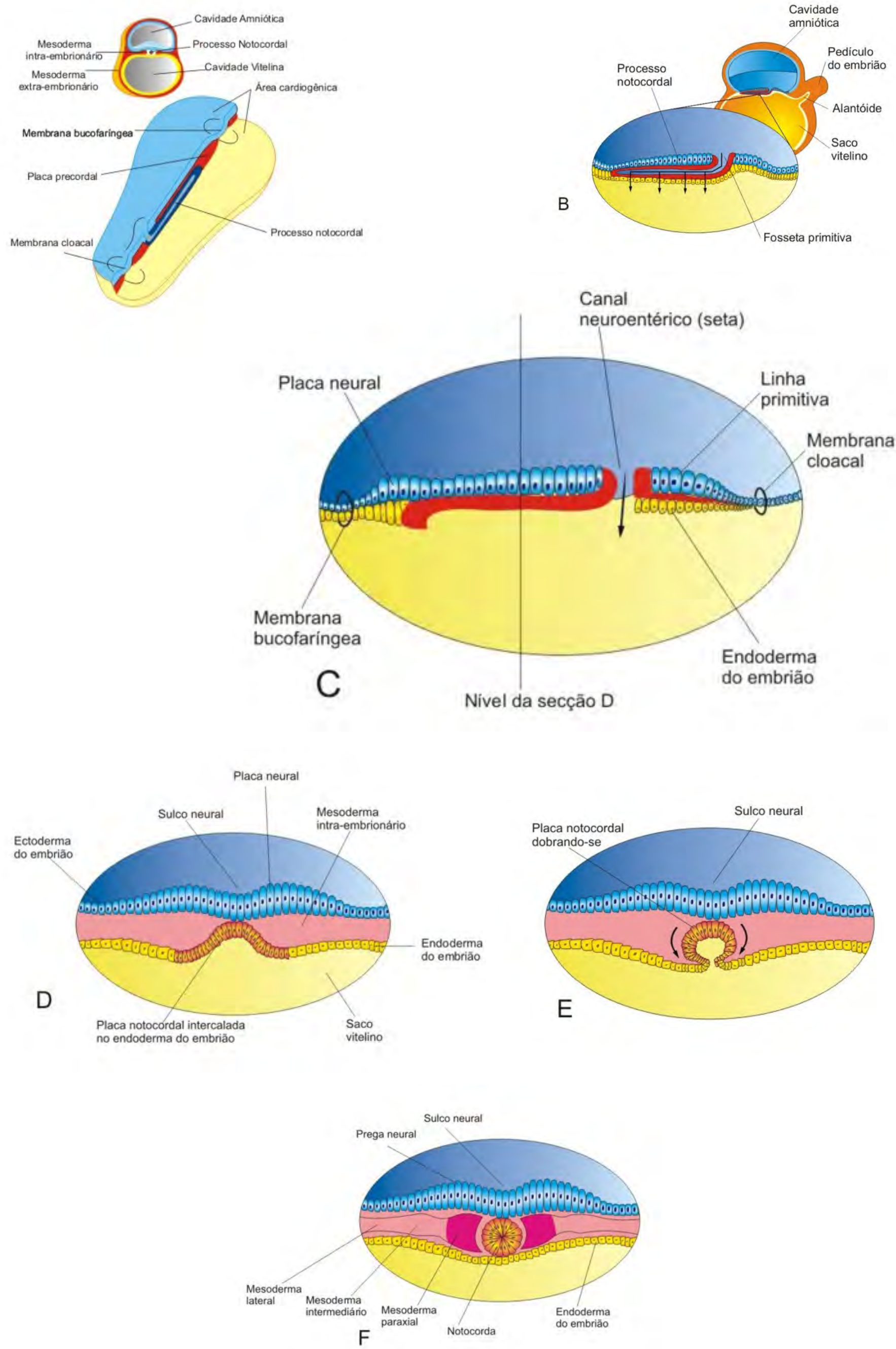


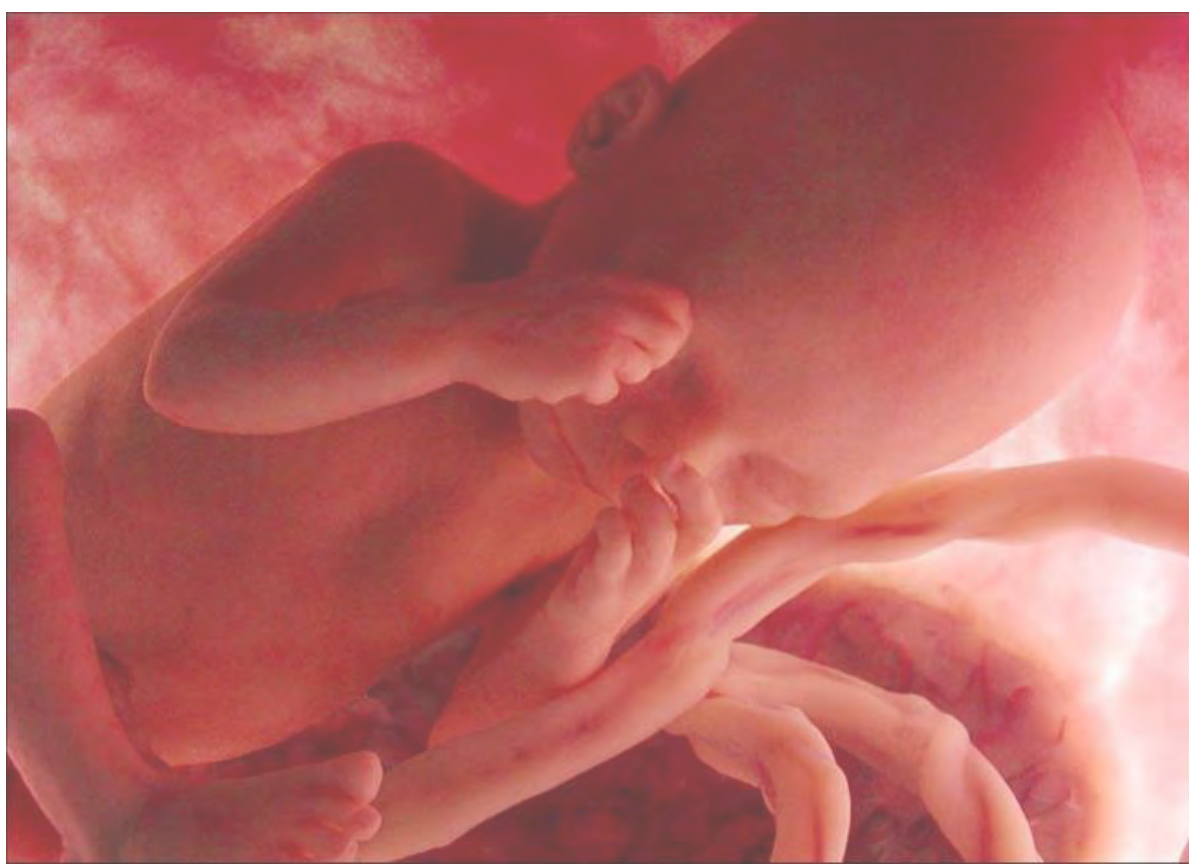

O saco vitelino e a alantóide são estruturas vestigiais, mas sua presença é essencial ao desenvolvimento normal do embrião. Ambos são sítios precoces de formação do sangue, e a parte dorsal do saco vitelino é incorporada ao embrião na forma de intestino primitivo. Células germinativas primordiais também se originam no saco vitelino.

O âmnio forma um saco que contém o líquido amniótico e fornece o revestimento do cordão umbilical. O líquido amniótico possui três funções principais: ele prevê: um anteparo protetor para o embrião ou feto; espaço para os movimentos fetais; e contribui para a manutenção da temperatura corporal do feto.

Segundo Cohen, B. B., algo interessante acontece durante o desenvolvimento do embrião na terceira semana: "enquanto a notocorda se desenvolve, um canal - chamado de canal neuroentérico - se abre através da linha primitiva, entre o saco vitelino e a cavidade amniótica. Temos uma troca de fluidos, passando da frente para trás e de trás para a frente do corpo. Acredito que isso é a base para o ritmo do sistema nervoso autônomo (o SNA governa os órgãos vitais). Ele é similar ao ritmo crânio-sacral. Penso que existe um ritmo básico no corpo, mas - como a música - existem muitas variações. O que acontece nesse ponto é a impressão desse ritmo primordial em todas as células”. (2008, p. 165)

Desta forma, Cohen, B. B. acredita que podemos identificar e convidar esse ritmo fluídico, pois ele ressoa em todas as células. "Ao invocar o canal neuroentérico ao invés do esqueleto axial, há um reconhecimento da conexão frente-trás ao invés das conexões cabeça-cóccix ou coluna/axial”. (2008, p. 166) 
Ao nos movermos por estruturas que não existem mais, segundo Cohen, B. B., movemo-nos através do lugar do espaço (the place of space). Os discos vertebrais e os ligamentos da coluna possuem a notocorda como ancestral, e dessa maneira, informam-nos sua memória e estabilizam o espaço central.

Em uma entrevista sobre o lugar do espaço, Cohen, B. B. mostra que, "estou me movendo através dos ossos da coluna; aqui (movendo-se novamente) estou na medula espinhal; aqui estou no espaço. Eu estabeleci o lugar do espaço, o lugar da notocorda. Quando eu enrolo minha coluna pelo sistema musculo-esquelético, tenho uma sensação de peso. Se vou pela notocorda, que não está mais aqui, mas apenas o seu processo, há uma sensação espacial. (...) Então, sinto que, quando as pessoas entram em estado meditativo ou participam de formas de movimentação mais internas como o Body Mind Centering ${ }^{\circledR}$, Movimento Autêntico (Authentic Movement), Dança Sufi, Contato Improvisação ou Katsugen Undo, existe um ponto em que nos conectamos com esse senso primitivo de espaço - claridade, facilidade e fluidez. Então estamos no lugar do espaço". (2008, p. 166)

Desta forma inconsciente, a música me conduziu ao lugar do espaço e criei a matriz "o jantar" que consistem em fazer nada. Concentro-me na sensação fluídica entre frente e trás do corpo, deixo meu olhar ser apoiado por ela, e, apenas olho para as pessoas na platéia, para os objetos a minha volta, para mim... Acolho o que surge e me sinto presente. 


\section{O ROTEIRO DE ANA-ME}

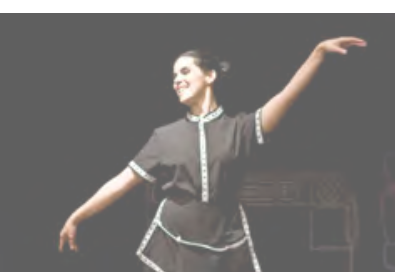

PRÓLOGO

Narradora 1 apresenta a história.

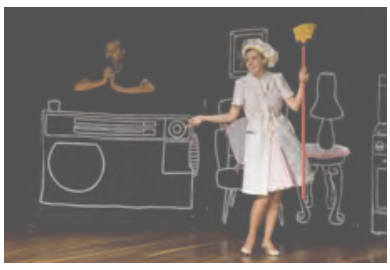

Anteparo sonoro: Cindy Lauper

Matriz: Limpar a casa - sistema muscular

Narração através de um programa de rádio

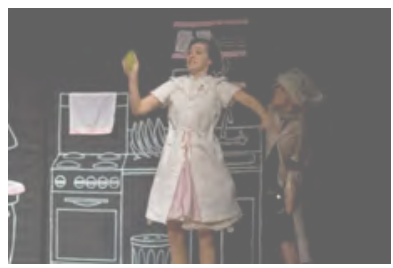

Anteparo sonoro: Música tecno

Matriz: Limpar a casa - sistema muscular B

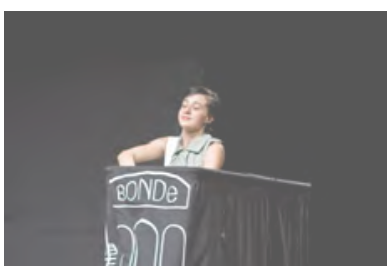

CENA 3

RUA

Matriz: Postura e gestos sistema ósseo

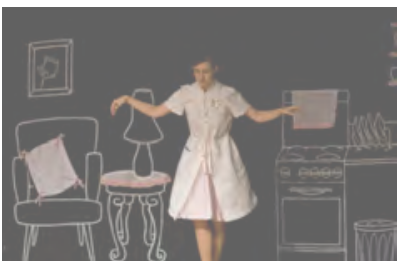

Anteparo sonoro: “A Morte do Cisne".

Matriz: Rápido dentro / Lento fora

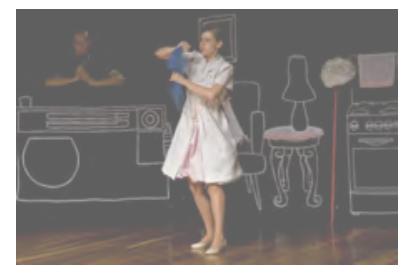

Anteparo sonoro: Cindy Lauper

Matriz: Limpar a casa - sistema muscular

Utilização de objetos

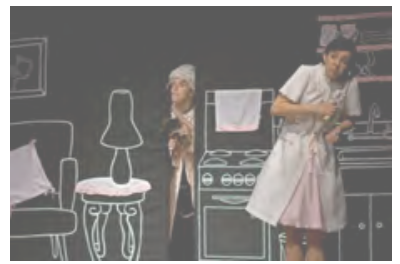

Matriz: Limpar a casa - sistema muscular e gestos sistema ósseo

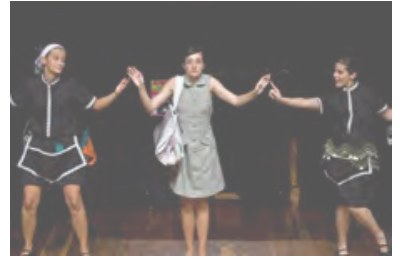

CENA 4

O SUPERMERCADO

Matriz: Sistema muscular A

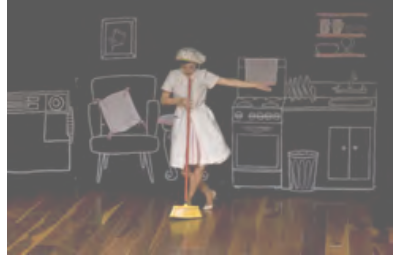

TRANSIÇÃO

Anteparo sonoro: Non Je ne Regrette Rien

Matriz: Edith Piaf e musculatura A

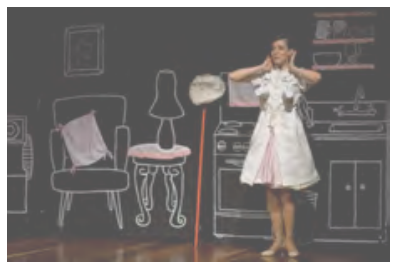

Anteparo sonoro: Cindy Lauper

Matriz: Limpar a casa - sistema muscular

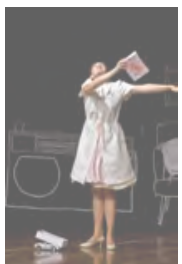

Matriz: Limpar a casa - sistema muscular A

Apresentação do sabão em pó

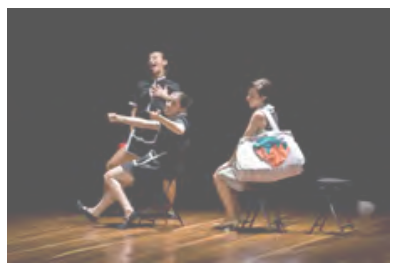

CENA 5

BONDE

Matriz: Ver o cego - sistema orgânico

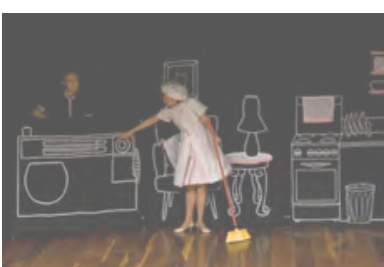

CENA 1

LIMPEZA E BELEZA

Anteparo sonoro: Cindy Lauper

Matriz: Limpar a casa - sistema muscular

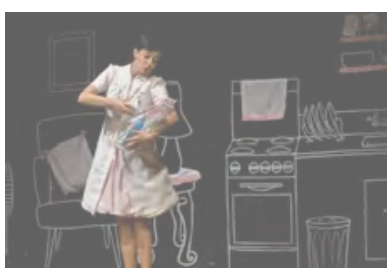

Anteparo sonoro: Cindy Lauper

Matriz: Limpar a casa - sistema muscular

Apresentação do filho

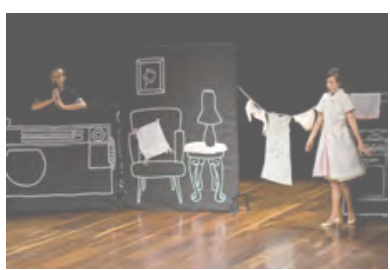

CENA 2

HORA PERIGOSA DA TARDE

Matriz: postura e gestos sistema ósseo

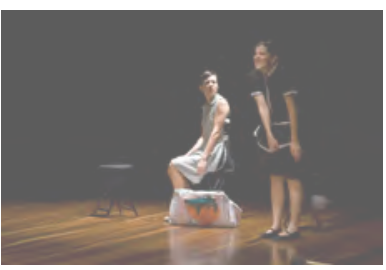

Matriz: Ver o cego - sistema orgânico 


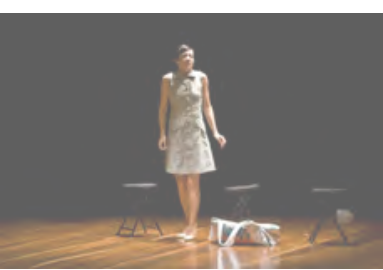

Matriz: Quando Ana vê o cego - Irradiação Umbilical - Boca-desejo que sorri e deixa de sorrir

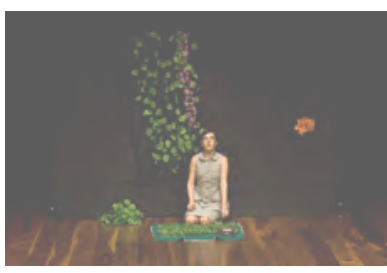

CENA 6

O JARDIM BOTÂNICO Anteparo sonoro: Ne me quitte pas

Matriz: Jardim Botânico sistema endócrino

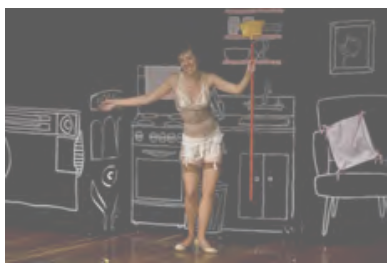

CENA 7

VOLTA PARA CASA

Matriz: sistema muscular e ósseo

Reutilização dos objetos

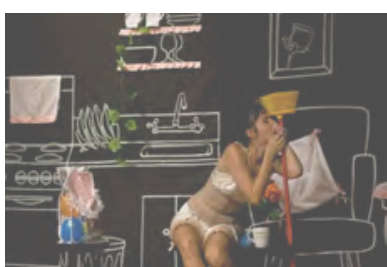

Anteparo sonoro: Adagio de Barber

Matriz: O jantar - consciência embrionária

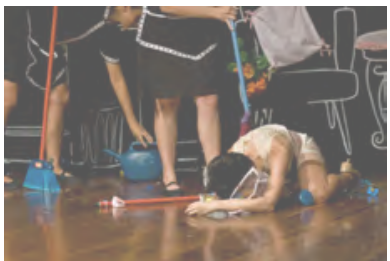

Matriz: sistema orgânico

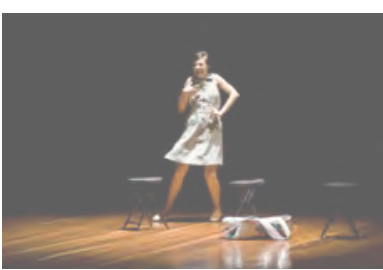

Matriz: Boca-desejo que debocha - sistema orgânico

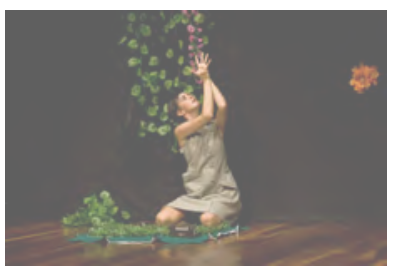

Anteparo sonoro: Ne me quitte pas

Matriz: Jardim Botânico sistema ósseo e endócrino

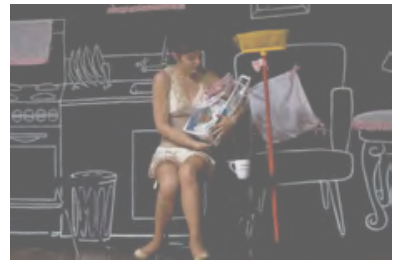

Matriz: sistema muscular e ósseo

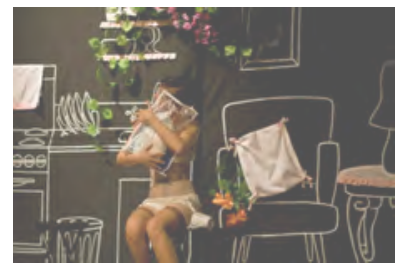

Anteparo sonoro: Adagio de Barber

Matriz: O jantar - consciência embrionária

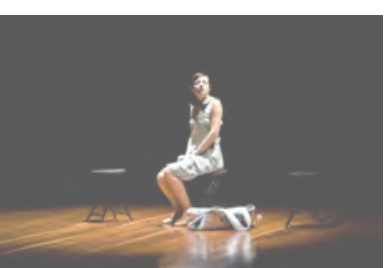

Matriz: Ana-umbigo da cena - Irradiação umbilical

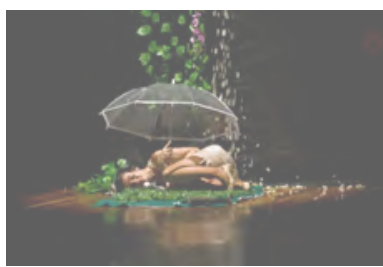

Matriz criada pela atriz Sandra Pestana

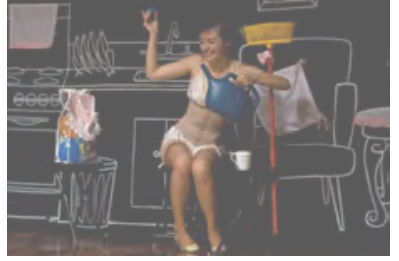

Matriz: sistema muscular e ósseo

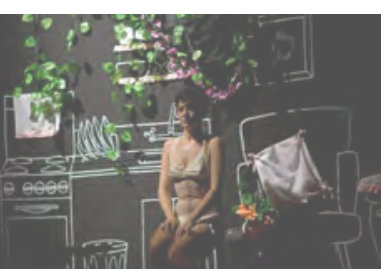

Anteparo sonoro: Adagio de Barber

Matriz: O jantar - consciência embrionária

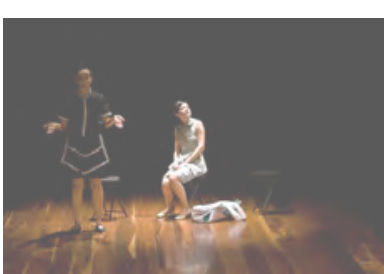

TRANSIÇÃO

Matriz: Ver o cego - sistema orgânico

Narradora 2 conduz Ana para o Jardim Botâico

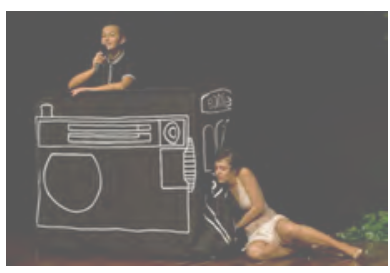

TRANSIÇÃO

Anteparo sonoro: Non je ne regrette rien

Matriz: Sistema muscular A

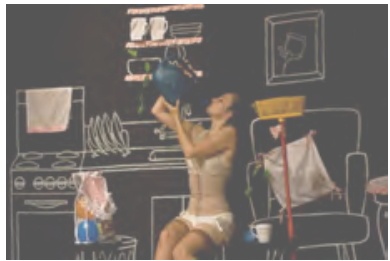

CENA 8

O JANTAR

Anteparo sonoro: Adagio de Barber

Matriz: O jantar - consciência embrionária

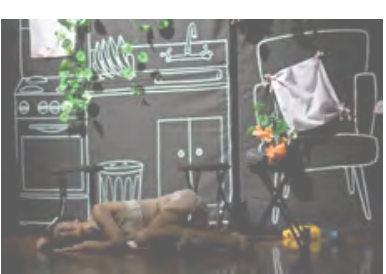

Anteparo sonoro: Adagio de Barber

Matriz: O jantar - consciência embrionária 


\section{CONSIDERAÇÕES FINAIS}

"O corpo-subjétil se autogere e se desvanece em continuum, agencia-se sobre momentos de desterritorialização acionados por punctums em estado virtual no corpo cotidiano, ao mesmo tempo em que esses mesmos continuuns que se desvanecem geram também zona de turbulência, criando um estado de jogo entre o corpo-subjétil em contato com o corpo-subjétil do outro ator, o público e o espaço”.

(FERRACINI, 2006 a, p. 190) 


\section{O PENSAMENTO DO ATOR}

Foram dois anos e meio de pesquisa e documentação que expandiram minha consciência em relação ao pensamento do ofício do ator. Tocada por todas essas experiências, acredito que a capacidade sutil e profunda de convidar a expressividade das células através do processo de corporificação nos conduz, antes de mais nada, à transformação e ao acolhimento.

Ao compreender que existem pensamentos e formas de expressão diferentes em nós mesmos, entendemos que podemos escolher. Olhar por outro ângulo, sentir de outro jeito, tomar outras atitudes. O outro se torna parte de nós mesmos. Vemos que a identidade está na alteridade. Ana se transforma ao ver o outro.

O processo de preparação de Ana-me contaminado pelo BMC®, permitiu a cartografia de meu próprio processo de aprendizagem e de minhas criações. Quais são as minhas tendências expressivas? Por qual caminho crio? Sempre faço a mesma coisa com formas diferentes? Minha visão de mundo está apoiada em que sistema? O que é preciso balancear? Porque eu reagi desta forma a este estímulo?

Acredito que esses questionamentos surgem porque o método pede a percepção ativa e sem julgamento sobre os grãos de areia que se movem ao sabor do vento, do pensamento. Todas as pequenas células têm sua especialidade e sua poesia. Os pensamentos sistêmicos possuem padrões de expressividade singulares e limitados, e essas características não são melhores ou piores, apenas são. Portanto, deve-se escolher.

Antes de ser uma técnica, o BMC® é uma prática que corporifica a observação, a atenção, a intenção e a ação. O conhecimento produzido por essa prática pode ser utilizado em técnicas de interpretação existentes, pois trata-se de alinhar intuição e forma, percepção e ação. Nada é excluído, tudo é observado, acolhido, sentido e "agido".

Desta maneira, exigiu-se de mim uma escolha ética, que tem heranças na fé defendida por Stanislávski; na contaminação e na violência exigida por Artaud; na comunhão ritualizada por Grotowski; na harmonia entre corpo, pensamento e sentimento pedida por Brook; na ação política enfatizada por Brecht; na hibridicidade e abertura praticada por Renato Cohen; na seriedade e constante busca realizada pelo Lume Teatro; na simplicidade e na coragem defendida pelo professor Armando Sérgio da Silva. 
Então, nesse caso, busquei em mim mesma as possibilidades de criação que, junto ao público, sejam contínuas, permeáveis, nômades, mutantes. E, essa dissertação é a sistematização de parte desse processo constante.

Quando Artaud abre o texto "Um Atletismo Afetivo", admitindo que existe, “no ator, uma espécie de musculatura afetiva que corresponde a localizações físicas do sentimentos” (ARTAUD, 1999, p. 151), ouso localizar o pensamento do ator: corporificar o encontro. Ou seja, o ator, na sala de trabalho, capacita-se em suas diferentes potências de sentir e agir, considerando seu corpo um espetáculo em si mesmo. E, sendo um espetáculo é, também, platéia, técnico, luz, som, etc. Ele atua, assiste, ilumina e esconde, escuta e ignora a si mesmo. E essas propriedades não estão, apenas, na musculatura. À luz do BMC®, os sentimentos estão nos ossos, nos órgãos, nas glândulas, no sangue, na linfa... e, inclusive, na memória de estruturas que compuseram o corpo no estágio embrionário como a notocorda.

Assim, no processo cênico em BMC®, o corpo-subjétil se pensa e se lança na corporificação de suas próprias multiplicidades. Cabe ao ator, “tomar consciência dessas localizações do pensamento afetivo” (ARTAUD, 1999, p. 157) e extrair resultantes que funcionam como marcas, materializações, catalizadores, trampolins dos bens imateriais atorais. É através da análise sobre essas resultantes que o ator pode perceber seus limites e suas trajetórias, e traçar novos objetivos com novas escolhas.

Vejo que, neste trabalho, as matrizes resultantes não possuíram palavra articulada. Desta observação, percebo minha deficiência em trabalhar o sistema vocal que, intuitivamente, não foi colocado em foco. A sonorização feita nos outros sistemas não foi explorada em sua potência expressiva, deixando, nesse momento de conclusão, uma lacuna e um novo desafio. Entretanto, ao acolher esse resultado, surgiu a forma de contar o espetáculo Ana-me, pois Ana não fala por si só, ela é narrada por programas de rádio, músicas, objetos e pessoas.

Por não ser excludente, o método se fundiu harmoniosamente com outras fontes criativas como o simbolismo místico, a situação ficcional, os anteparos, os conceitos, e todas as referências que, de alguma forma, fazem parte de mim e me movem. Seus cruzamentos permitiram ressignificâncias e transformações como observamos na transposição das matrizes em signos teatrais. 
Se olharmos com atenção o processo, percebemos que as matrizes não passaram por repetições para se tornarem código, ou a codificação não passou pela repetição - caminho mapeado por Ferracini em sua tese de mestrado: "Repetição e enclausuramento dos micro-elementos e das microtensões de cada ação física orgânica, partindo do pressuposto de que o corpo é memória: essa é a proposta do Lume para a codificação das ações físicas”. (FERRACINI, 2001, p. 125)

Os códigos já estavam contidos nas próprias matrizes. Ao estipular portas de entrada (variáveis e inerentes a cada estado corporal) estabelecia, também, a substância que lhes conferia a forma. Por exemplo, se os gestos resultaram do pensamento das mãos, eles já são codificados, porém abertos. A matriz "gestos" guarda em si o que a motivou, podendo ser formalmente transformada. Ela pode ser apoiada por outro sistema, dependendo do espaço/tempo em que será (re)criada.

As experiências das apresentações do espetáculo Ana-me me mostraram que essas matrizes suficientemente abertas e apropriadas, possibilitam a maleabilidade da escolha durante a cena. Devido à corporificação profunda dessas matrizes pude modificá-las de acordo com minhas sensações presentes, reagindo ao humor do ambiente e do público. Com isso, o roteiro do espetáculo se abriu para novas experimentações estéticas, conservando sua macro-estrutura.

Outro aspecto relevante que permeou esse processo foi a necessidade de percorrer esta jornada com princípios do BMC® dentro de uma pedagogia teatral. E aqui adotei a "Oficina da Essência" que desenhou as margens e conduziu os focos de criação, delimitando as fases da preparação. Pois a prática BMC®, como disse anteriormente, é um método de educação do movimento e pode ser utilizado dentro de diversas áreas do conhecimento.

Retomando os objetivos dessa pesquisa, observo que o método escolhido atendeu minhas expectativas e criou novos estímulos para sua continuidade. Através da aplicação dos princípios nesse processo, corporifiquei as diferentes potencialidades criativas de cada pensamento sistêmico; codifiquei em matrizes as sensações percebidas; preparei a figura de Ana, um amálgama sintético das percepções corpóreas; investiguei formas para o encontro com o público, e sua hibridicidade se deu através do acolhimento inerente ao método;

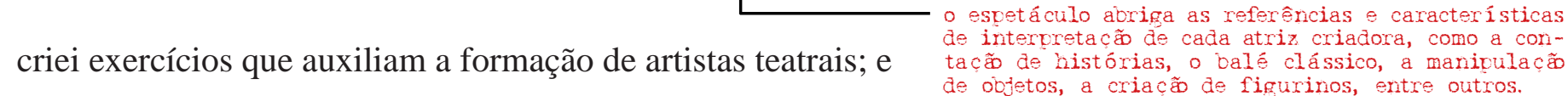


e tudo de forma autônoma e atoral.

O diálogo entre conceitos e prática aconteceu de forma intensa e ingênua. Analiso, aqui, meu encanto e minha fragilidade em relação aos pensamentos filosóficos de Deleuze, José Gil e Derrida. Na tentativa de me apropriar de suas palavras, sentia-me pequena e, contraditoriamente, livre e sufocada. Pois a articulação desses pensamentos impulsionavam minha intuição e minha prática, ao mesmo tempo que, embaralhavam e fragilizavam meu percurso teórico.

As inquietações em relação ao Corpo sem Órgãos (CsO) deleuziano, levaram-me ao entendimento de minha postura ética: perceber minhas estratificações e rompê-las; criar linhas de fuga; ir em direção ao limite; observar organismos sociais, políticos, familiares e religiosos em meu próprio corpo, em minhas próprias percepções e ações. Conduziu-me à consciência de que os princípios do BMC® são meu método e prudência para arrancar, dos órgãos, o organismo, e tentar conporificar o ovo pleno.

Embora, a terminologia $\mathrm{CsO}$ não apareça durante a descrição dessa jornada, ela esteve sujacente e permitiu a cartografia da corporificação do espaço do corpo. Pois, através das manifestações sistêmicas, esquematizei matrizes provenientes de modulações energéticas, que são as diferentes matérias que compõe um CsO, ou seja, qual o desejo que percorre o corpo, fazendo-o desejar; como nos fala, José Gil, “duas condições são necessárias para que o corpo onde fluem intensidades se forme: a) que o espaço interior, esvaziado, se revele sobre a pele, constituindo então a matéria do $\mathrm{CsO}$; b) que a pele, impregnada do espaço interior, se torne a matéria-corpo do corpo pleno (espaço do corpo incluído)”. (2004, p. 63)

Minha escolha recaiu, então, na síntese do emprego dos conceitos. Desta forma, tentei abordá-los como mapas ou guias para a reflexão teórica sobre a práxis cênica. O mesmo se deu com o conceito de subjétil desenvolvido por Derrida: ele se uniu ao corpo-subjétil discorrido por Ferracini.

Assim, as resultantes práticas provenientes dos princípios do BMC ${ }^{\circledR}$ dialogaram com punctums, matrizes e espaços do corpo. É interessante, ainda, notar que cada pensamento sistêmico influenciou na escolha de seu intelocutor teórico, por exemplo, sistema ósseo e punctum, e sistema orgânico e espaço do corpo. Além de contribuirem com a forma textual das descrições.

Por fim, ressalto o caráter preparatório dessa pesquisa, que uniu o trabalho do ator sobre si mesmo e 


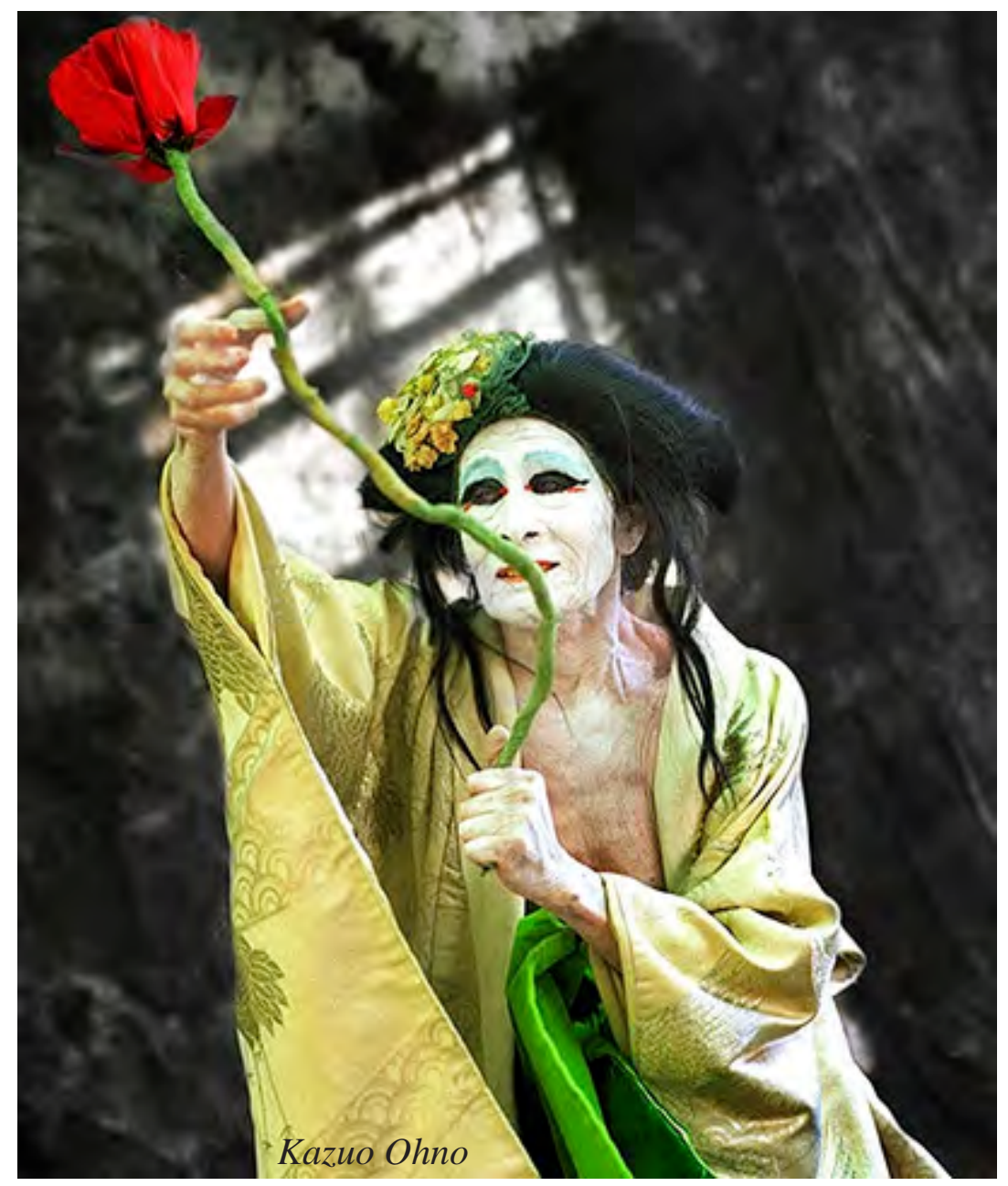


a preparação da personagem. Desta união, o processo de preparação de Ana guiou meu trabalho como atrizpesquisadora-pessoa.

Ana vive em seu cotidiano e, através de um estímulo, ela tem a consciência da vibração do espaço ao seu redor, dilatando seus sentidos, atualizando memórias e se percebendo. Depois disso, Ana pode agir e criar ações no mundo.

Eu vivo meu cotidiano - fecho meu apartamento alugado na cidade de São Paulo; pego ônibus e trânsito; corro e chego ao ensaio. Lá, me preparo, pois diferentemente de Ana, já tenho a intenção da epifania e, através de minha sensibilidade e objetivo no ato da criação, percebo meus próprios estados corporais, minhas dilatações sensíveis. E, a partir daí, as condenso, organizo, registro e escolho. Crio portas de entrada que as ativem. Assim, posso agir, elaborar e estudar ações no espaço, corporificando encontros.

Desta forma, concluo que o processo de corporificação entendido pelo método BMC® potencializa e dinamiza a criação de um corpo-subjétil-poético-cênico.

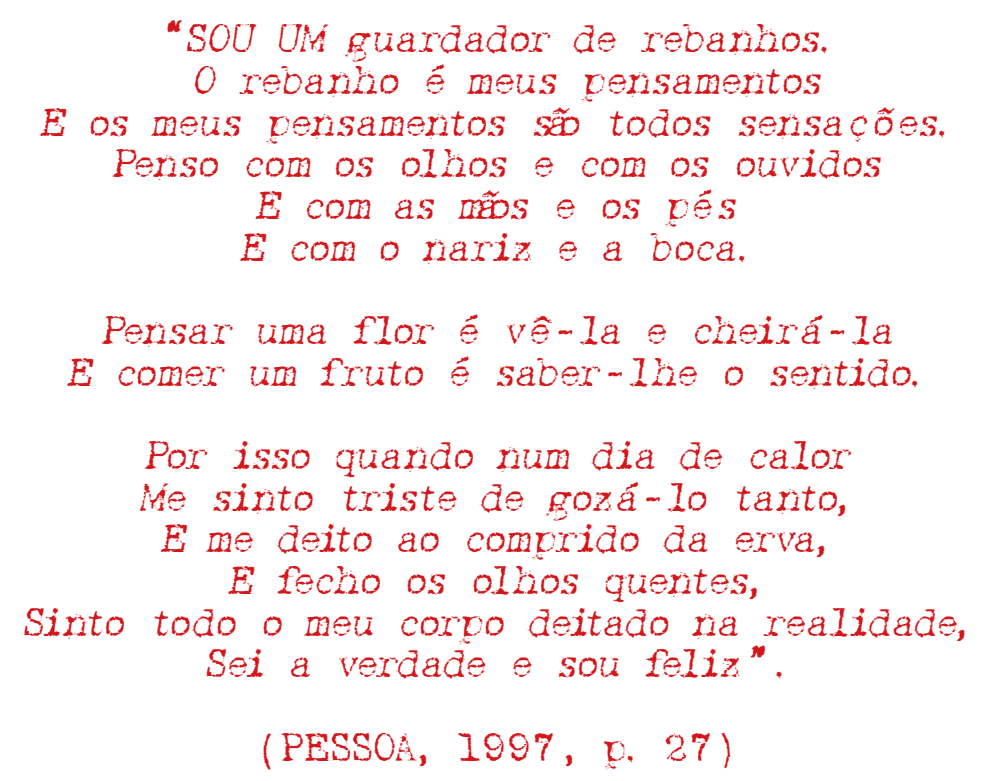


BIBLIOGRAFIA 
ARTAUD, Antonin. Escritos de Antonin Artaud. Seleção e notas de Cláudio Wille; vol.5. São Paulo: L\&PM, 1986. Coleção Rebeldes Malditos. . Linguagem e Vida. São Paulo: Perspectiva, 2004. . O Teatro e seu Duplo. Trad. Teixeira Coelho. São Paulo: Martins Fontes, 1999. Coleção

Tópicos.

AZEVEDO, Sônia Machado de. O Papel do Corpo no Corpo do Ator. São Paulo: Editora Perspectiva, 2002. Coleção Estudos.

BAIOCCHI, Maura. Butoh: Veredas D’Alma. São Paulo: Palas Athenas,1995.

BARBA, Eugenio e SAVARESE, Nicola. A Arte Secreta do Ator: Dicionário de Antropologia Teatral. Trad. Luis Otávio Burnier (supervisão), Carlos Roberto Simioni, Ricardo Puccetti, Hitoshi Nomura, Márcia Strazzacappa, Waleska Silverberg. Campinas: Ed. Hucitec e Ed. Da Unicamp, 1995.

BAUMAN, Zygmunt. Identidade - entrevista a Benedetto Vecchi.Trad. CarlosAlberto Medeiros. Rio de Janeiro: Jorge Zahar Ed., 2005.

. Amor Líquido: Sobre a Fragilidade dos Laços Humanos. Trd. Carlos Alberto Medeiro.

Rio de Janeiro: Jorge Zahar Ed., 2004

. Comunidade: a busca por segurança no mundo atual. Trad. Plínio Dentzien. Rio de Janeiro: Jorge Zahar Ed., 2003.

BERGSON, Henri. Matéria e Memória - Ensaio sobre a Relação do Corpo com o Espírito. São Paulo. Martins Fontes, 1990.

BONFITTO, Matteo. O Ator Compositor. São Paulo: Perspectiva, 2002.

BROOK, Peter. A Porta Aberta: Reflexões sobre a Interpretação e o Teatro. Trad.: Antonio Mercado - $2^{a}$ ed. - Rio de Janeiro: Civilização Brasileira, 2005.

Brasileira, 1994.

. Ponto de Mudança, Trad. Antonio Mercado e Elena Gaidano. Rio de Janeiro: Civilização

BURNIER, Luis. A Arte do Ator: da Técnica à Representação. Campinas. Editora da Unicamp, 2001.

. A arte do Ator. In: Corpos em Fuga, Corpos em Arte. Organizador: Renato Ferracini. São Pau-

lo: Aderaldo \& Rothschild Editores Ed.: Fapesp, 2006. p. 25 a 27.

CHAUÍ, Marilena. Convite à Filosofia. São Paulo: Editora Ática, 1994.

COHEN, Bonnie Bainbridge. Sensing, Feeling and Action: the Experimental Anatomy of Body-Mind Centering. Northampton, Massachusetts: Contact Editions, 2008.

COHEN, Renato. Work in Progess na Cena Contemporânea. São Paulo: Perspectiva, 1998.

. Performance como Linguagem. São Paulo: Perspectiva, $2^{\mathrm{a}}$ ed., 1989.

DAMÁSIO, Antonio. O Erro de Descartes: Emoção, Razão e Cérebro Humano. Trad. Dora Vicente e Georgina Segurado. São Paulo: Companhia das Letras, 1996.

. Em Busca de Espinosa: Prazer e Dor na Ciência dos Sentimentos. Adaptação para o português do Brasil Laura Teixeira Motta. São Paulo: Companhia das letras, 2004.

DANGELO, J. G. e FATTINI, C.A. Anatomia Humana Básica. São Paulo : Atheneu, 1995.

DELEUZE, Gilles. Francis Bacon: Lógica da Sensação. Trad. Roberto Machado (coordenação), Aurélio Guerra Neto, Bruno Lara Resende, Ovídio de Abreu, Paulo Germano de Albuquerque, Tiago Seixas Themudo. Rio de Janeiro: Jorge Zahar Editor, 2007.

DELEUZE, G e GUATTARI, F. O que é Filosofia? Trad. Bento Prado Jr e Alberto Alonso Muñoz. - Rio de Janeiro: Editora 34, 1992.

Célia Pinto Costa - Rio de Janeiro: Editora 34, 1995.

. Mil Platôs: Capitalismo e Esquizofrenia. Vol.1. Trad. Aurélio Guerra Neto, Mil Platôs: Capitalismo e Esquizofrenia. Vol.3. Trad. Aurélio Guerra Neto,

Célia Pinto Costa - Rio de Janeiro: Editora 34, 1995.

Janeiro: Editora 34, 1997. . Mil Platôs: Capitalismo e Esquizofrenia. Vol.4. Trad. Suely Rolnik - Rio de

DELEUZE, G e PARNET, Claire. Diálogos. Trad. Eloísa Araújo Ribeiro - São Paulo: editora escuta, 1998.

DERRIDA, Jacques. Enlouquecer o Subjétil. São Paulo: Unesp, 1998. 
FERNANDES, Ciane. O Corpo em Movimento: o Sistema Laban / Bartenieff na Formação e Pesquisa em Artes Cênicas. São Paulo: Annablume, 2006.

FERRACINI, Renato. A Arte de não Interpretar como Poesia Corpórea do Ator. Campinas: Editora da Unicamp, 2001.

Fapesp, 2006 a. . Café com Queijo: corpos em criação. São Paulo: Aderaldo \& Rothschild Editores, Ed.

Fapesp, 2006 b. Corpos em Fuga. Corpos em Arte. São Paulo: Aderaldo \& Rothschild Editores, Ed.

GADAMER, Hans-Georg. Verdade e Método I: Traços Fundamentais de uma Hermenêutica Filosófica. Trad. Paulo Flávio Meurer. Petrópolis, RJ: Ed. Vozes, 1997.

GARAUDY, Roger. Dançar a Vida. Trad.: Glória mariani e Antônio Guimarães Filho. Rio de Janeiro: Nova Fronteira, 1980.

GIL, José. Movimento Total. São Paulo: Iluminuras, 2004.

GREINER, Christine. Butô: Pensamento em Evolução. São Paulo: Escrituras Editora, 1998. . O Corpo: Pistas para estudos Indisciplinares. São Paulo: Annablume, 2005.

GROTOWSKI, Jerzy. Em Busca de um Teatro Pobre. Trad. Aldomar Conrado. Rio de Janeiro: Civilização Brasileira, $3^{\text {a }}$ ed. 1987.

HARDT, Michael e NEGRI, Antonio. Multidão. Trad. Clóvis Marques. Rio de Janeiro: Record, 2005.

HARTLEY, Linda. Wisdom of the Body Moving: An Introduction to Body-Mind Centering. Berkeley: North Atlantic Books, 1995.

HERRIGEL, Eugen. A Arte Cavalheiresca do Arqueiro Zen. São Paulo: Editora Pensamento, 2001.

KATZ, Helena. Um, Dois, Três: a Dança é o Pensamento do Corpo. Belo Horizonte: Helena Katz, 2005.

KELEMAN, Stanley. Anatomia Emocional. São Paulo: Summus Editorial, 1992.

LEHMAN, Hans Thies. Teatro Pós-Dramático. Trad. Pedro Süssekind. São Paulo: Cosac Naify, 2007

LISPECTOR, Clarice. Laços de Família: Contos. Rio de Janeiro: Rocco, 1998.

MARIZ, Adriana Dantas de. A Ostra e a Pérola: Uma Visão Antropológica do Corpo no Teatro de Pesquisa. São Paulo: Perspectiva, 2007.

MILlMAN, Dan. O Caminho do Guerreiro Pacífico: um livro que modifica vidas. São Paulo: Editora Pensamentos, 2000.

MIRANDA, Evaristo Eduardo de. Corpo: Território do Sagrado. São Paulo: Edições Loyola, 2000.

ORNELLAS. Raquel. Caldeirão de Bruxas: de como Macbeth virou Irmãs do Tempo. São Paulo: Editora da Universidade de São Paulo, 2006.

PESSOA, Fernando. Guardador de Rebanhos. In: Poemas Escolhidos. Seleção e organização: Frederico Barbosa. São Paulo: Klick Editora, 1997. p. 16 a 45.

SILMAN, Naomi. Os Instrumentos do Canto. In: Corpos em Fuga, Corpos em Arte. Organizador: Renato Ferracini. São Paulo: Aderaldo \& Rothschild Editores Ed.: Fapesp, 2006. p. 46 a 49.

SILVA, Armando Sérgio da. Interpretação: uma oficina da essência. São Paulo: Cópia Reprográfica Fêo Copiadora, 2003.

SÓFOCLES. Rei Édipo. In: Teatro Grego. Sel., trad., e org.: Jaime Bruna. São Paulo: Editora Cultrix, 1968.

STANISLAVSKI. Constantin. A Construção da Personagem. Rio de Janeiro: Editora Civilização Brasileira S.A., 1976.

Civilização Brasileira, 1986. . A Preparação do Ator. Trad.: Pontes de Paula Lima. Rio de Janeiro: Editora

Civilização Brasileira, 1999.

A Criação de um Papel. Trad.: Pontes de Paula Lima. Rio de Janeiro: Editora

TSIARAS, Alexander e WERTH, Barry. The Architecture and Design of Man and Woman: the marvel of the human body, revealed. Japão: Doubleday, 2004.

TURNER, Victor W. O Processo Ritual: Estrutura e Anti-Estrutura. Trad. Nancy Campi de Castro. Petrópolis: Vozes, 1974.

VESALIUS, Andreas. De Humani Corporis Fabrica. Epitome. Tabulae Sex. Trad. Pedro Carlos P. lemos e Maria Cristina V. Carnevale. São Paulo: Ateliê Editorial; Editora Unicamp; Imprensa Oficial, 2002. 


\section{Artigos publicados em Jornais, Revistas e Sites}

BONDÍA, Jorge Larrosa. Notas sobre a Experiência e o Saber de Experiência. Revista Brasileira de Educação. Trad.: João Wanderley Geraldi. v. 19. p. 20-28. jan/fev/mar/abr. 2002.

BROOK, Annie. The Artistic Muse of Creation and Supportive Embodied Implementation: Performance Art using principles of Body-Mind Centering ${ }^{\circledR}$ Attention/Intention. Body Mind Centering ${ }^{\circledR}$ and the Arts. Site: http://www.bmcassoc.org/files/AnnieBrook_SacredDance.pdf

CARREIRA, André Luis. O Risco Físico na Performance Teatral. Site: http://www.casthalia.com.br/periscope/andrecarreira/texto1andre.htm

DAWSEY, John C. Turner, Benjamin e Antropologia da Performance: O lugar olhado (e ouvido) das coisas. Site: http://74.125.47.132/search?q=cache:bZ2VfYv4ElEJ:ojs.c3sl.ufpr.br/ojs2/index.php/campos/article/viewPDFInterstitial/7322/5249+dawsey+turner+benjamin+e+performance\&cd=1\&hl=ptBR\&ct $=$ clnk\&gl $=$ br

EDDY, Martha. The Practical Application of Body Mind Centering ${ }^{\circledR}(B M C \circledR)$ in Dance Pedagogy. The Journal of Dance Education. v. 6, n. 3. C.M.A: Ed. D., R.S.M.T. , 2006. Site: http://www.bmcassoc.org/files/ MarthaEddyJODE2006v6n3.pdf

FERRACINI, Renato. Fronteiras, paradoxos e micropercepções. Site: http://www.renatoferracini.com/meuslivros

FRIEDMAN, Susan S. O "falar da fronteira”, o hibridismo e a performatividade: Teoria da cultura e identidade nos espaços intersticiais da diferença. Eurozine. Site: http://www.eurozine.com/articles/2002-06-10friedman-pt.html

SANTIBÁÑEZ, Guy. Dialéctica de los Procesos Subjetivos. Revista de Psicología. Año / vol. XI, n. 001. Universidad de Chile. Ñuñoa Santiago, Chile. p. 65-90. Site: http://redalyc.uaemex.mx/redalyc/pdf/264/26411106. pdf

\section{Monografias, Dissertações e Teses}

BRITO, Giselle R. De Água e Sal: uma abordagem de processo criativo em dança. Dissertação de mestrado. Instituto de Artes. Universidade de Brasília, Brasília, 2006.

NUNES, Sandra Meyer. As Metáforas do Corpomídia em Cena: Repensando as Ações Físicas no Trabalho do Ator. Tese de doutoramento. Programa de estudos pós-graduados em comunicação e semiótica. Pontifícia Universidade Católica de São Paulo, São Paulo, 2006.

OLIVEIRA, Rosa de Souza. Olhares Epifânicos: a Epifania nos Contos "Amor" de Clarice Lispector e " Sexta-feira" de Luandino Vieira. Dissertação de Mestrado. Faculdade de Filosofia e Letras. Universidade de São Paulo, São Paulo, 2000.

QUEIROZ, Clélia F. P. Corpulações: Informação e comunicação. Movimento e contato. Tese de doutoramento. Programa de estudos pós-graduados em comunicação e semiótica. Pontifícia Universidade Católica de São Paulo, São Paulo, 2007.

\section{Apostilas}

PEES, Adriana Almeida. Manual do Sistema Ósseo. Apostila distribuída no curso Formação em Integração do Movimento Somático®, ministrado por Adriana Almeida Pees, em São Paulo, 2006. . Manual do Sistema Orgânico. Apostila distribuída no curso Formação em Integração do Movimento Somático®, ministrado por Adriana Almeida Pees, em São Paulo, 2006. . Manual do Sistema Muscular. Apostila distribuída no curso Formação em Integração do Movimento Somático ${ }^{\circledR}$, ministrado por Adriana Almeida Pees, em São Paulo, 2006. . Manual do Sistema Endócrino. Apostila distribuída no curso Formação em Integração do Movimento Somático®, ministrado por Adriana Almeida Pees, em São Paulo, 2006. . Manual do Sistema Fluído. Apostila distribuída no curso Formação em Integração do Movimento Somático ${ }^{\circledR}$, ministrado por Adriana Almeida Pees, em São Paulo, 2006. 
Manual dos Padrões Neurológicos Básicos (PNB). Apostila distribuída no curso Formação em Integração do Movimento Somático ${ }^{\circledR}$, ministrado por Adriana Almeida Pees, em São Paulo, 2006.

. Manual do Sistema Nervoso. Apostila distribuída no curso Formação em Integração do Movimento Somático®, ministrado por Adriana Almeida Pees, em São Paulo, 2006.

. Manual do Sistema Sensorial e Percepção. Apostila distribuída no curso Formação em Integração do Movimento Somático ${ }^{\circledR}$, ministrado por Adriana Almeida Pees, em São Paulo, 2006.

\section{Sites}

Sobre BMC®:

http://www.bodymindcentering.com/

http://www.bmcassoc.org/

Sobre sistema ósseo:

http://www.afh.bio.br/sustenta/sustenta1.asp. Acesso em: 29 mai. 2009.

http://www.afh.bio.br/sustenta/sustenta2.asp. Acesso em: 29 mai. 2009.

http://auladeanatomia.com/osteologia/generalidades.htm. Acesso em: 29 mai. 2009.

Sobre sistema orgânico:

http://patymari.sites.uol.com.br/digestivo.htm. Acesso em: 01 jun. 2009.

http://www.brasilescola.com/biologia/sistema-digestivo.htm. Acesso em: 01 jun. 2009.

Sobre sistema muscular:

http://www.portalsaofrancisco.com.br/alfa/corpo-humano-sistema-muscular/index.php. Acesso em: 17 jun. 2009

http://www.webciencia.com/11_28musculos.htm. Acesso em: 17 jun. 2009.

http://www.sobiologia.com.br/conteudos/Corpo/sistemamuscular.php. Acesso em 17 jun. 2009.

http://www.auladeanatomia.com/sistemamuscular/gen-musc.htm. Acesso em: 17 jun. 2009.

http://www.csj.g12.br/info/corpohumano/Sistema_Muscular.htm. Acesso em: 17 jun. 2009.

Sobre sistema endócrino:

http://www.webciencia.com/11_23endo.htm. Acesso em: 06 jul. 2009.

Sobre embriologia:

http://www.forp.usp.br/mef/embriologia/geral.htm

Sobre células:

http://www.ufmt.br/bionet/conteudos/15.07.04/morf_org.htm 
ENCARTE 


\section{ANEXO I: RELATOS DAS ATRIZES}

“Ingressei na Faculdade de Artes Cênicas da Unicamp junto com a Débora. Isso podia não significar nada, mas nossos caminhos seguiram bem juntos e se cruzaram em muitos momentos. Assim, esse percurso que ela traça de maneira tão singular e individual faz muito sentido para mim, pois acompanhei parte de sua construção.

Assim, em muitos momentos no meu percurso com atriz, minhas descobertas foram desencadeadas na observação do trabalho dela; e no estímulo de suas palavras conduzindo ensaios, treinamentos, pesquisas.

Meu relato em relação à experiência criativa a partir do BMC® começa no ano de 2004 quando Débora, intuitivamente começou explorar esse universo ainda sem nome, sem "técnica", conduzindo exercícios para preparação corporal da Zero Zero Cia de Teatro. Embora nessa ocasião nem ela nem nós conhecêssemos o BMC®, foi lá que esse trabalho teve seu início, pois em todas as outras vezes que Débora conduziu novamente exercícios conosco, já mais embasados pela técnica, era como se eu continuasse um trabalho iniciado nesses ensaios de 2004, tão forte havia sido essa experiência.

Começamos pelos ossos. Passávamos muito tempo, eu diria horas, mapeando os ossos. Eu mergulhava nesses exercícios com muita concentração. A princípio não compreendia os ossos em sua fisicalidade. Eles eram imagem, eram desenho de esqueletos (como Pedrinho esqueleto de uma história infantil que eu lia). Eu tinha medo de bater meus ossos. Eles não tinham proteção para caminhar. Lembro que no primeiro ensaio eu não podia levantar, caminhar. Os ossos ainda não tinham peso, espessura, mas acredito com a memória embaçada pelo tempo e contaminada por experiências posteriores, que a percepção "fisicalidade" dos ossos, foi minha primeira "descoberta", e como se uma chave fosse virada, percebi uma qualidade de movimento bem diferente das experimentadas até então.

É claro que mesmo assim essa percepção é muito diferente da que tenho hoje, e da percepção adquirida anos depois nos trabalhos feitos posteriormente. Na ocasião ajudavam nessa percepção diferenciada a disposição, concentração e o tempo dilatado para as descobertas.

O trabalho com os órgãos que deu-se na seqüência teve, também, um significado especial, pois na 
tentativa de escapar da imagem, e buscar as dimensões dos órgãos, construí um trabalho profundo e emocionante. Vermelho carne. Eu me sentia viva e expressiva nesses ensaios e era perceptivel o envolvimento das pessoas em volta. A atmosfera construída, e os exercícios que foram criados coletivamente tinham outro peso, outra cor. Eu me sentia descobrindo meu trabalho.

Os ensaios foram interrompidos, e nós só voltamos a ter experiências com o BMC® em 2006. Dessa vez, Débora já havia iniciado um curso sobre o assunto, e os ensaios eram voltados para um tema especifico. Trabalhamos a matriz peitoral (ossos), respiração, sistema circulatório. Em alguns desses ensaios nós escrevíamos cartas, poemas a partir dos exercícios. Os escritos eram ricos de imagens, poemas concretos alimentados pelas experiências físicas. Nesses dias, o jogo entre as propostas físicas e as imagens era constante. Toda proposta fisica, quando executada, virava imagem e isso transformava novamente o movimento. Débora estava contaminada por esse universo e isso era presente em sua condução, em suas ações, em seu discurso. Acolhimento era a palavra forte. Acolher o entendimento sobre aquilo, acolher as imagens suscitadas, acolher o que era desencadeado por aquilo. Era dificil para mim não ser "boa aluna", e acreditar no caminho intuitivo que meu corpo seguia a partir daquela proposta. Eu queria saber o que era o "certo". Acolher era necessário no momento. Me acolher, acolher o grupo em constante desarmonia. Esse trabalho me ensinou, pouco a pouco, a acolher e confiar no caminho que meu próprio corpo escolhia sabiamente para dar seqüencia ao meu processo como atriz.

Esse trabalho, como o outro, foi interrompido e voltamos a ter uma breve experiência com o BMC já no que seria o Teatro de Senhoritas (Companhia formada por mim, Débora e Sandra em 2007). Dessa vez, a intenção era preparação para o espetáculo entre Divas e Senhoritas dirigido pela Débora. Imagino que ela precisasse deixar-nos mais vivas em cena, menos cristalizadas. Mas eu e Sandra estávamos trabalhando com força, com tensão, acho que a cabeça brigava com o corpo e tenho poucas lembranças do meu percurso corporal durante esse tempo.

Depois de estreado esse espetáculo, em 2008, com os corpos levemente viciados nessas personagens, Débora nos convida para participar mais efetivamente de sua pesquisa e da construção do espetáculo até então chamado de "Amor". Sua idéia era que eu cuidasse da dramaturgia do espetáculo e Sandra, do 
figurinos, mas que a gente fizesse isso a partir das experiências com o BMC ${ }^{\circledR}$. Para isso, ela deveria conduzir alguns ensaios preparatórios, mas aos poucos nós deveríamos criar uma forma independente de criação.

Seguiram-se maravilhosas experiências com o BMC®. Nas quais era possivel perceber o corpo já mais maduro do que há dois anos. Foi nessa imersão que iniciei uma real compreensão do trabalho com $B M C \circledR$. Comecei a compreender (e digo comecei, pois ainda sinto que existem milhares de incógnitas) esse diálogo entre o corpo, o pensamento, a experiência. A condução que parte do pensamento, e a compreensão que se dá no corpo e o caminho de volta".

\section{A dramaturgia e o $B M C \circledR$}

"Para desenvolvimento da criação dramatúrgica do espetáculo "Ana-me" consigo distinguir a utilização de três apoios centrais: a experiência prática e fisica despertada a partir do trabalho com o BMC® proposto por Débora Zamarioli; a linha narrativa do texto "Amor", de Clarice Lispector; experiências provindas do trabalho como contadora de histórias. Embora nesse momento seja possível distinguir esses três pontos, durante o processo eles se confundem. Assim será também durante minha descrição do processo.

Alguns anos antes da proposta de construir a dramaturgia do espetáculo "Ana-me" a partir das vivências com o BMC, já havíamos feito uma experiência similar. Eu e Débora fazíamos ainda parte da Zero Zero Cia de Teatro e na busca por uma nova criação, Débora conduziu algumas oficinas de BMC, depois das quais nós realizamos registros escritos, algumas vezes em forma de poesia ou carta. Já nessa ocasião, percebi o que acabou se confirmando durante o processo de "Ana-me”, as imagens suscitadas pelas experiências corpóreas colaboravam para uma escrita bem diferenciada do texto. Ou seja, um texto conduzido a partir desses experimentos tinha qualidade muito diferente de textos escritos sobre a mesma temática em outros contextos.

Porém, para além dessa percepção, o processo de “Ana-me" aprofundou a relação não só dos textos escritos, como também da estrutura dramaturgica e os pontos de tangenciamento entre meu trabalho de contação de histórias, dramaturgia e o BMC.

As experiências iniciais desse processo foram intensivas e bastante contundentes. Eu saia dos 
ensaios contaminada pelos princípios estudados. E entre meus registros muitas vezes eu falo da percepção estudada durante o encontro perdurando ao longo da noite ou do dia.

Essas experiências me sugeriam imagens, e idéias para o espetáculo. As vezes, alguns textos surgiam. Textos que muitas vezes foram aproveitados na montagem final, e outros que serviram como suporte para criação. O texto abaixo pode é um exemplo de um texto não utilizado no espetáculo, criado em um desses momentos pós ensaio.

'E de repente estou...

e estou no banco do cego

e quase posso sentir o chiclete em minha boca.

Minha mala ao lado é o meu cão guia.

E a vista é a melhor do ônibus.

Certamente não para quem conduz.

Mas a melhor vista está em frente à porta.

A rua recortada como num quadro cubista.

Não é curiosa a vista panorâmica de um cego?'

Este trabalho também influenciava minha leitura tanto de crônicas, artigos, contos, quanto de propagandas, estímulos visuais. Um exemplo dessa contaminação foi a descoberta de um texto de Pablo Neruda após um estudo sobre a pele (em meus registros escrevo "pele de dentro").

'Não será a morte afinal

uma cozinha interminável?

Que farão teus ossos desmembrados,

Buscarão outra vez tua forma?

Se fundirá tua destruição

em outra voz e em outra luz?

Teus vermes irão fazer parte

de cachorros ou de mariposas?' (Pablo Neruda - Livro das perguntas) 
As imagens provocadas nessa ocasião foram fortes me sugeriram algumas cenas que eu propus posteriormente. Assim se dava o diálogo. Existia a escuta da proposta fisica, a reverberação disso no corpo, o processamento das imagens provocadas, e a transformação disso em proposta cênica, dramaturgica.

Uniu-se a isso a necessidade de desenvolver um processo próprio de criação do Teatro de Senhoritas. Assim, tentei unir as minhas experiências anteriores a essas experiências com o BMC, dentro do processo de criação dessa peça. Intuitivamente, senti que deveria unir algumas "técnicas" que utilizo no meu trabalho como contadora de histórias a esse processo. Dessa forma, propus uma manipulação de objetos a partir do estudo dos ossos e da pele. Diferentes qualidades, jogos, matrizes, imagens e histórias. E depois de incessantes experimentos (alguns mais certeiros que outros), chegamos à construção da primeira cena da peça.

Tentando ainda estabelecer um diálogo entre essas "técnicas", propus um estudo do conto "Amor" utilizando técnicas de estudo e divisão de texto. Desenvolvemos uma espécie de "storyboard" da peça, no qual a linha narrativa do conto passaria a ser utilizada como esqueleto da criação; o esqueleto seria visto como organizador, elemento de sustentação e articulação do espetáculo; porém, como os alicerces de uma construção, deveria permanecer escondido.

Para isso, seguindo a experiência de estudo de texto desenvolvido no meu trabalho de contação de histórias, inicialmente separarei o texto em partes (oito ou nove, seguindo padrão estudado e desenvolvido por Regina Machado e adaptado por mim) e nomearei as partes afim de iniciar uma compreensão mais profunda do eixo utilizado por Clarice e suas articulações. A partir desse apoio, poderei construir a linha narrativa corroborando, ou transformando à proposta pela autora.

Depois de definido o "esqueleto" e nomeados os "ossos" (subdivisões do texto), foram incluidos nesse "storyboard" todas as referências que já tínhamos em relação a esse processo: cores, objetos, textos, imagens. Numa analogia, diria que colocamos ali, de forma desordenada, os demais sistemas do corpo.

A partir daí, durante a criação, nos afastamos muito desse esqueleto, deixando novas imagens e personagens participarem de uma história inventada, para depois retomar uma forma mais próxima da original". 
“Bem... Acho que o primeiro contato com o BMC eu tive quando todas nós ainda não sabíamos, nem mesmo a Débora, que aquelas experiências que fizemos em Campinas era, essencialmente, BMC.

Desse período, a lembrança mais marcante não é pessoal, mas sim o relato de uma colega, que havia tido problemas psiquiátricos fazia pouco tempo e que não pôde "dançar com seus órgãos", pois lhe remetia aos momentos obscuros que havia vivido. Dentre todos, acho que esse foi o relato mais sincero naquele dia. Bem... Depois a intuição da Débora guiou-a para o BMC e este trouxe pedras mais firmes para o caminho.

Enquanto isso, na 'sala da justiça'eu e Isis gestávamos as Srtas. Miriam e April, personagens do Entre Divas e Senhoritas, patinando em um labirinto, com duas personagens-máscara que queriam fazer Tennessee Williams... Através de treinamentos com o método BMC, conseguimos que as personagens se apropriassem melhor do espaço, dos objetos, e nós, atrizes, nos apropriamos das quebras propostas pela direção, do texto, da encenação... E só então eu consegui definir como seriam os figurinos.

Bem... Enquanto disso, em outra 'sala da justiça', a Débora gestava OféliaAmorAna, quando nós entramos para gestar AnamídiaAna-me.

Dividimos o trabalho em prática com o método BMC, dinâmicas com objetos, experimentos com textos e criação de cenas para o espetáculo. E uma coisa permeava a outra, o BMC permeando tudo.

No princípio eu iria fazer apenas os figurinos, mas fomos entrando no universo, na peça, em cena... Antes que o espetáculo se configurasse com ele é atualmente, eu vi várias vezes à cena do Jardim Botânico, em que Ana fica de roupa intima, muito frágil e bastante exposta. E eu gostava bastante dessa imagem. Então iniciei a criação dos figurinos de Ana-me a partir dessa proposta. E como não fui apenas figurinista do processo, mas fiz parte dele como atriz e como pesquisadora do Método BMC, diversos pontos desses trabalhos foram levados elou influenciaram para a criação da indumentária. Os figurinos foram criados das peças mais intimas para as mais superficiais, foi preciso primeiro o esqueleto, a estrutura de sustentação da personagem, para posteriormente revesti-lo. Denomino este figurino como estrutura de sustentação, pois Ana pareceu-me tão frágil que não se manteria de pé sozinha.

Agregada a essa fragilidade estava a imagem de bonequinha do lar, de mulher perfeitinha, , e Ana foi definindo-se cada vez mais que como tal. Assim, Ana vestida era quase uma bonequinha, Ana semi-nua era 
como uma marionete. Por isso a escolha do espartilho, da cinta liga e da sobreposição de peças, tudo em tom bege clarinho, para dar essa idéia de sustentação (espartilho) e linhas (da cinta, das alças), como se aquelas peças fizessem parte do corpo dela. O espartilho também contribui para o realce da matriz peitoral, um dos pontos de partida da criação da personagem, já que sublinha tanto para o público (visualmente), quando para a atriz (fisicamente), essa região do corpo.

A segunda etapa foi justamente o figurino intermediário entre a Ana bonequinha da casa e a Ana exposta após a experiência no Jardim Botânico: a Ana bonequinha de papel, no estilo recorte e cole, a mulher pronta para todas as ocasiões. A peça escolhida deveria remeter ao universo do conto, do Rio de Janeiro da década de 1950/1960, e também periodo em que as bonecas de papel faziam parte do dia-a-dia das garotas.

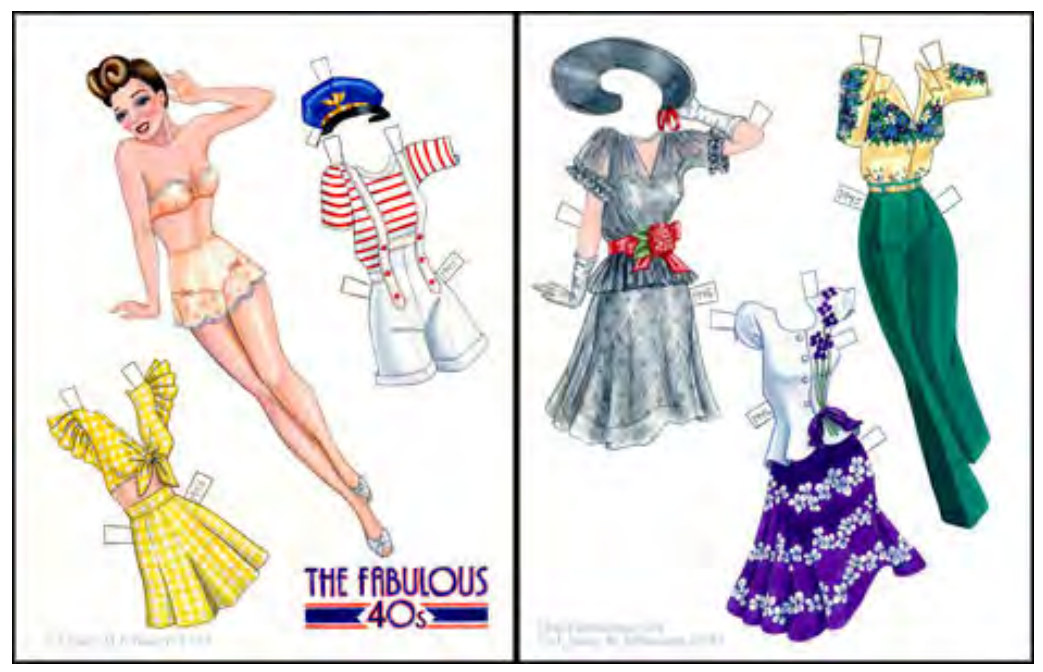

Para a última peça de Ana, usamos um robe com corte evasê, que com a ajuda de uma estrutura metálica enfatizou a matriz dos braços e realçou as linhas dos movimentos".
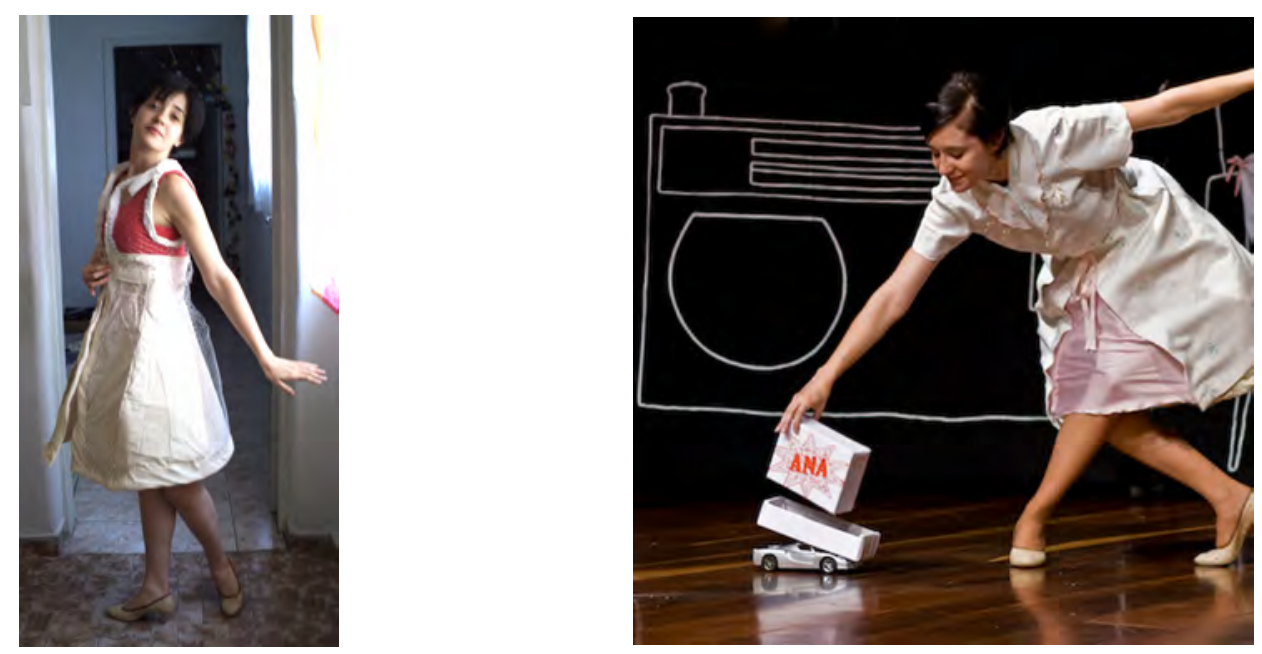


\title{
ANEXO II: ANA-ME
}

\author{
ANA-ME, \\ de Isis Madi e Teatro de Senhoritas
}

Prólogo

NARRADORA I: Ana-me. Feche os olhos e voe. Num tempo em que as crianças nasciam com os olhos abertos, num apartamento entre a estação Liberdade e o Jardim Botânico, vivia Ana. Ana não era igual nem diferente de nenhuma de nós. Como todos em sua época ela também nasceu com os olhos abertos e assim permaneceu. Depois de uma infância feliz com seus pais, Ana saiu de casa em busca do seu próprio núcleo familiar. Casou-se com um marido exemplar, que supria as necessidades da casa. Teve um filho exemplar, que também nasceu com os olhos abertos, para a alegria da família. E, como todos em sua época, ela também tinha sonhos aprisionados, que aparceiam as três horas da tarde para amedrontá-la. Assim, Ana seguiria sua vida, não fosse por um descuido (acidente?). Num piscar de olhos, Ana chegaria de um momento a outro, nova por alguns minutos, distinta, quase estranha. Envolta pela primeira vez pelo ar da rua. Coberta de olhares e ruídos que se separariam lentamente dela, até morrer no chão e tornar-se, outra vez, igual.

(Ana entra no fundo ao centro, entre as araras do cenário. Ela dança a morte do cisne de uma forma bem particular. A perfeição da forma clássica se intercala à beleza da imperfeição de um movimento que possui outra expressividade. Durante toda a encenação Ana não fala por si, mas age normalmente.)

Cena 1

\section{Limpeza e Beleza}

(Ana se relaciona com os objetos na ação de limpar e arrumar a casa. Os objetos acabam determinando algumas personagens da peça. Por exemplo, o marido é a vassoura, seu filho é um saco de guardar travesseiros cheios de objetos que determinam sua idade e caracteristica.)

(Terminada a dança, Ana se coloca parada no palco, as duas atrizes entram trazendo uma touca térmica e uma vassoura. Ana começa a varrer de forma desanimada. Vai até o rádio gigante colocado a esquerda do palco e muda a estação. Dentro do rádio gigante aparece a locutora.)

LOCUTORA: (toca uma música da Cindy Lauper) Boa tarde. São 13 horas. Você está ouvindo o especial Cindy Lauper (Ana se anima e começa uma coreografia com a vassoura. No meio dessa dança ela passa por momentos de extrema animação. As vezes olha para o lado para ver se ninguém está vendo. As vezes varre e as vezes faz malabarismos com a vassoura.)

VIZINHA: Ana, (Ana vai até o rádio e abaixa o volume) Tá tudo bem aí, querida? Parece que eu ouvi um barulho...

(Ana sorri sem graça e continua seu trabalho. Limpa a vassoura. A música muda e inicia-se uma música mais romântica. Aos poucos a vassoura se transforma no marido e Ana começa a dançar com ele)

LOCUTORA: Você está ouvindo o especial Cindi Lauper no "Dicas de beleza" que são Tudo-de-Bom. Hoje, eu, Greice Lima, dou dicas para você que conquistou o seu marido como uma princesa e não pode virar um dragão! Atenção querida ouvinte, todas as nossas armas e segredos de beleza devem ser mesmo nossos segredos. Nada de usar cremes faciais, bobs e toucas térmicas na frente dos nossos tremendões! (Ana se dá conta de que está de toca térmica e se esconde atrás da vassoura). Essas são coisas que devem ser feitas em momentos que ele nunca, nunca verá! (Com a touca, Ana cobre o que seriam os olhos da vassoura/marido). 
(Ana volta a arrumar a casa, pega paninhos de tirar pó, limpa alguns lugares. Surgem duas xícaras de dentro do cenário. Ana vai até elas e as pega)

LOCUTORA - Você deve aparecer para ele sempre pronta, sempre linda, como num passe de mágica, para isso, aproveite os momentos de arrumação da casa para dar um UP no seu visual. (começa a música que lembra um mambo) (Ana, que estava de costas no fundo do palco, se vira com duas xícaras no peito. Ela inicia uma dança sensual para a vassoura/marido. No ápice da empolgação, o filho mais novo-representado por um saco de guardar travesseiros recheado de fraudas e coisas de bebê- surge chorando de dentro do cenário. Ana acode, muda de estação. Uma narração de história infaltil começa).

LOCUTORA: (vinheta para inicio de história infantil) Minu o cabritinho. Minu era um cabritinho muito especial, ele não enxergava nada e por isso nunca saia de perto da mãe, tanto que ele conseguia sentir o cheiro dela e de seus irmaozinhos. Um dia, Minu sentiu o cheiro de um trevo muito especial e foi seguindo o seu faro. Quando se deu conta, não mais escutou o sino de sua mãe e nem dos outros que aparentemente tinham seguido em frente. Minu correu desesperado pra lá e pra cá e cheirava e cheirava e tudo parecia estranho ao redor. Ele andou e andou, até que se perdeu! (Enquanto ouve a história, Ana acalenta o filho, tirando as xícaras do peito e dando-lhe de mamar. Ele dorme. Ana devolve o filho para o cenário)

LOCUTORA - Atenção querida ouvinte! Olhe para a sua casa, ela está um lixo e você também? Não perca tempo! Declare guerra contra a sujeira e a gordura localizada! (uma corneta toca e Ana se prepara para a guerra. Ela recebe como arma uma escovinha de limpeza, e começa a limpar a casa e fazer ginastica ao mesmo tempo. Música tecno. Percebe-se a vizinha limpando a casa atrás do cenário). Mulher, mulher, na escola que vc foi ensinada eu jamais tirei um 10, sou forte, mas não chego aos seus pés. É o nosso tremendão incentivando a nossa malhação. Vamos lá é você quem carrega esse país nos braços, mais uma série. E 1 e 2 e 3 e 4. E atenção para essa dica: Quando passar a escovinha no ladrilho da cozinha, aproveite para passar nas unhas. (Música aumenta) Essa dica é um oferecimento de Candidarina. Você deixa de fazer carinho no rosto de seu marido por causa do cheiro da cândida que gruda nas mãos, então experimente a nova "candidarina”, a única cândida com glicerina, suas mãos ficam suaves e cheirosas e seu pano de chão continua alvejado e branco e pode ser asteado como uma flâmula do seu aceio doméstico diante das suas vizinhas!

(Ana e a Vizinha que ouviu todas as dicas, se irritam com a radialista e jogam suas escovinhas no rádio. A locutora tenta falar e Ana desliga o rádio. Logo depois a Locutora através de um controle remoto faz entrar um carrinho com o Sabão em Pó Ana. Ana sede e a Locutora volta a falar.)

LOCUTORA - Esse programa tem um oferecimento do sabão em pó ANA, a Limpeza que não engana. (Jingle)

(Ana transforma-se na máquina de lavar roupa. Lava, centrifuga e estende as roupas no varal. Som de tiquetaque.. O primeiro vazio aparece. Ana começa a se agitar)

\section{Cena 2}

Hora perigosa da tarde

LOCUTORA - 14h58minutos. Calma querida ouvinte, estamos quase na hora perigosa da tarde, quando a casa já está arrumada e limpa, as crianças estão no colégio e o tremendão ainda demora para chegar. Mas fique tranquila, nós vamos atravessar juntas esse vazio. E você ainda tem que recolher a roupa. (Ana percebe que as roupas estão secas e as recolhe. Quando volta, vê-se que está vestida com a roupa que estava pendurada) (Tique-taque seguido de três badaladas)

LOCUTORA: Agora sim, 15h começamos a nossa "Hora Perigosa da Tarde”. Hoje lerei a carta de uma ouvinte que editará um livro com textos inspirados nesse momento. Vamos à ela: "Eu vivo um eu descolado de 
mim. Há lugar para mim nesse universo acolchoado que me cerca? Eu abro os olhos e vejo minha cortina rosa de vincos bem passados. Meus pés tocam um carpete limpo e quente. Meus móveis não tem quinas. Mas eu fecho os olhos e existe um abismo de ardósia. As vezes eu me vejo pequena no fundo do abismo. As vezes eu caio nele sem parar... Por isso, decidi manter os olhos abertos.”. Obrigada pela sua participação. Experimente você também, querida ouvinte, papel e caneta na mão. (música adágio. Ana não consegue se mover.)

LOCUTORA: Participe do nosso programa: mande para gente o que você escreveu! E se não foi hoje que você descobriu a sua veia literária, não tem problema. Verifique a dispensa. Essa também é uma boa hora para ir às compras. (Surge uma sacola de compras e Ana sai de casa)

\section{Cena 3}

\section{Rua}

(Ana abre a porta de casa com um gesto. Ouve-se o barulho da rua. Ana volta, pega o rádio gigante, coloca fones de ouvido e sai caminhando com ele. Uma música se inicia e o cenário de araras começa e se movimentar. Ana entra dentro do rádio gigante e vira-o, nesse momento percebemos que a outra face desse rádio é a frente de um bonde. Aparecem personagens da cidade: um cego, uma prostituta, um vendedores ambulantes no semáforo...)

\section{Cena 4}

Supermercado

(Inicia-se uma música árabe. Uma das atrizes, a gerente, coloca um lenço com medalhas e a outra, a funcionária, uma touca, enquanto montam o supermercado.)

GERENTE: (Som abaixa) Olá Dona de Casa, seja bem vinda ao SuperCadão. Não deixe de comprar refirgerantes (a funcionária vira os produtos pendurados conforme a gerente anucia), produtos de limpeza, e papinhas de nenê pela metade do preço! (Música volta. Ana entra no mercado)

GERENTE: Pare! (música pára) olhe! Compare! E para olhar é preciso ter olhos sadios. A vitamina A é a vitamina da boa visão. Ela é encontrada nos legumes principalmente nas cenouras. Cenouras, cenouras, cenouras! Eis a salada para os seus olhos! E com os olhos sadios você pode ver até os nossos precinhos! (Música).

(Ana pega as cenouras e coloca em sua bolsa. Depois pega o sabão em pó, mas ele não é da marca certa! Então, a gerente dá sinal e entra o carrinho de controle remoto com o sabão em pó Ana - a Limpeza que não engana. Inicia-se o Gingle do sabão. Ana o pega e, satisfeita, passa no "caixa” com seus produtos. Sai do mercado.)

GERENTE: Obrigada e volte sempre! E para vc que acabou de chegar, não perca o nosso show de ofertas. Hoje aqui vamos cometer um atentado contra os preços baixos!! Vá até o nosso açougue e compre maminhas, fraldinhas e filé mingon pela medate do preço. (A funcionária se coloca na frente das araras. Surge uma bexiga em cima de sua cabeça. A gerente tem uma faca nas mãos.) Que rufem os tambores! (som de tambores rufando. A gerente atira a faca contra a bexiga). (Som de aplausos).(Inicia-se som de um bonde enquanto as atrizes movem o cenário.)

\section{Cena 5}

Bonde

(Barulho de rua, pessoas falando, vendedores. Três banquinhos são colocados em cena, eles representam o bonde. Ana senta-se. Ela tem o olhar perdido e desinteressado. Novas e anteriores personagens da cidade 
surgem: um motorista, um vendedor ambulante no semáforo, uma prostituta, uma mãe agressiva. Um cego retira um chiclete do bolso e se aproxima. Ele masca o chicletes e seu rosto se move, sorrindo e deixando de sorrir) (Ana vê o cego)

NARRADORA I - Assim, Ana seguia sua vida, sem desviar um passo do caminho destinado. Mas um dia, não se sabe por quê. ..Ela não se atrasou, ela não se adiantou. O bonde era o mesmo de sempre. Talvez por isso, por tudo parecer como sempre. Ana se distraiu e sem querer piscou, encostou a cabeça sobre a janela. Reconfortou-se no sol que alcançava os seus olhos e... a verdadeira loucura da vida permanece acima de qualquer descrição.

(Ana vê o cego mascando chiclete. A partir disso, ela começa a observar as pessoas na rua e cada uma desperta uma emoção em Ana. Ela vê uma puta dando risada e mexendo nos seios; um jovem casal de namorados prestes a se beijar; uma mulher brigando com o filho; e o cego. Ana vê e se transforma nessas "personagens", passando por emoções despertadas até que tudo se mistura. No final vemos apenas o cego e Ana, como se ela o observasse e tivesse o desejo de beijá-lo.)

NARRADORA II - Ela fizera tanto, tudo e tão direitinho para que um dia se seguisse ao outro, para que nada se quebrasse e de repente um cego mascando chicletes. Era só um cego mascando chicletes. Numa súbita brecada, Ana desperta com a sacola espatifada no chão, tudo esparramado, os ovos se quebraram. Tudo se quebrou. A pele craquelada. Ana sentia a náusea doce de quando a alma vem até a boca. Levanta-se cambaleante, percebe que há muito passara de seu ponto e salta do bonde. Sentia-se perdida. Sentia-se com a alma nas mãos. Como se pela primeira vez aquelas mãos pequenas e fortes que cosiam seu destino a pontos apertados pudessem ser usadas para destruir. Sentia nas mãos um muro áspero, um muro alto, conhecido: o Jardim Botânico. (A narradora abre a sacola de compras que por dentro é revestida de grama artificial)

\section{Cena 6}

\section{Jardim Botânico}

(Ana senta num banco no Jardim Botânico e começa a olhar ao seu redor. Ela vê e se transforma na paisagem. (música Ne Me Quitte Pas) Ana olha as árvores; uma aranha; frutos; frutas em decomposição. Aos poucos, percebemos que o Jardim desperta em Ana as emoções de medo, raiva, erotismo, alegria e tristeza. Lá ela tem seu momento de epifania. Seu cotidiano, agora, parece um "modo moralmente louco de viver".)

(Ana chora no chão em cima do carpete de grama. A narradora I entra e lhe entrega um guarda chuva. Começa a chover folhas secas, depois cai água de um regador. Depois inicia-se uma chuva de pedras. Enquanto isso, a narradora I fala)

NARRADORA I - Cada encontro é diferente. Cada um reage de um jeito. Uns querem ajudar, muitos sentem pena. Outros a gente não encontra, por que para eles é horrível demais. Muitos são gentis, outros acham interessante, muitos desandam a falar de seus avôs e avós que eram cegos ou que a pior coisa que poderia acontecer a eles seria ficarem cegos. A rotina é prestar atenção e isso enche o saco. Ser observado também é rotineiro. Quando eu ando, as vozes se calam pelo caminho por onde eu passo e voltam a falar depois que eu passei. Pena, pena sentir pena da minha deficiência explícita. É difícil de aturar por que eu mesma acabo ficando sentimental. (No fim da chuva de pedras, a narradora I pega o rádio pequeno na frente de Ana. Inicia-se a música "Je ne regret rien")

\section{Cena 7}

Volta para casa

LOCUTORA: (entra com o rádio gigante, ela traduz a música Je ne regret rien) Boa noite! Pra vc que ligou e pediu: Eu não me arrependo de nada" com Edith Piaf (Durante a cena, o Jardim Botânico é desmontado e 
a casa de Ana é montada.)

Non, rien de rien - não, nada de nada

Non, je ne regrette rien - não, eu não me arrependo de nada

Ni le bien qu'on m'a fait - nem o bem que me fez

Ni le mal, tout ça m’est égal - nem o mal, tudo isso me é igual

Non, rien de rien - não, nada de nada

Non, je ne regrette rien - não, eu não me arrependo de nada

C’est payé, balayé, oublié - nem o bem que está acabado e esquecido

Je me fout du passé - eu tiro sarro do passado

Avec mes souvenirs - com minhas recordações

J'ai allumé le feu - eu acendi o fogo

Mes chagrins, mes plaisirs - minhas aflições, meus prazeres

Je n’ai plus besoin d'eux - eu não os preciso mais

Balayés mes amours - meus amores idos

Avec leurs trémolos - com seus tremores

Balayés pour toujours - sempre esquecidos

Je repars a zéro - Eu recomeço do zero

Non, rien de rien - não, nada de nada

Non, je ne regrette rien - não, eu não me arrependo de nada

Ni le bien qu'on m’a fait - nem o bem que me fez

Ni le mal, tout ça m’est bien egál - nem o mal, tudo isso me é igual

Non, rien de rien - não, nada de nada

Non, je ne regrette rien - não, eu não lamento nada

Car ma vie, car mes joies - porque minha vida, minhas alegrias

Pour aujourd'hui - para hoje

Ça commence avec toi - começam com você"

Love Nights” pra você que é sentimental.

\section{Cena 8}

Jantar

(Ana retoma a posição inicial em casa. Ouve-se os passos do marido, chegando) ( A vassoura entra em cena. Ana se relaciona com o marido. Mas alguma coisa está diferente. Eles se abraçam, ela o afasta e ele vai tomar banho. Ela tenta falar alguma coisa. Não consegue. Liga o rádio.)

LOCUTORA - (Enquanto a locutora fala, Ana prepara a "mesa do jantar", colocando três banquinhos em cena) Muito boa noite, querida ouvinte! Hoje o Love Nights é pra você que teve imprevistos e não conseguiu preparar o jantar. Não tem problema. Não fale nada para o tremendão! Enquanto ele toma banho prepare um super hiper prático suflê de cenouras! As cenouras são ricas em vitamina A, aquela que combate a chamada cegueira noturna, o que a gente sente quando entra no escuro do cinema e fica aflito por não conseguir distiguir coisa alguma. Abuse da cenoura nos momentos em que a vida te surpreende e... bom apetite!

(O marido entra. A locutora coloca uma música para o drinque. Surge do cenário o regador e uma xícara. Ela prepara a bebida para o marido. Senta-se no colo dele, os dois se abraçam. A campainha toca e as atrizes copeiras servem chicletes e bebidas para as pessoas da platéia. Ana tenta falar novamente, mas não consegue)

LOCUTORA - Sejam bem vindos. Que bom que vocês chegaram. O programa coma com Jazz começa agora. Fiquem à vontade. Sirvam-se dos aperitivos, enquanto o jantar não fica pronto, e relaxem!

(O bebê chora. Ele aparece do cenário novamente. Ana o coloca em um dos banquinhos. O jantar fica pronto. Surge do cenário uma travessa com cenouras. Ela "estoura" o champanhe abrindo o regador, bebe o conteúdo. Começa uma música adágio. Ana olha a sua volta, faz como se estivesse conversando com o público 
e sua família. Aos poucos sua movimentação a remete ao Jardim Botânico e à cidade. Isso a faz, lentamente, devorar seu marido e seu filho. Tudo fica despedaçado. As flores e folhas que compunham o Jardim Botãnico entram na casa. Ana, calmamente, olha diretamente para a platéia. Depois deita-se ao lado dos restos do filho e do marido)

ANA - Querido, é difícil para mim imaginar fugir do dia a dia. O que você faz quando as xícaras estão todas no lugar? Ou as suas nunca estão no lugar. Eu estou tentado fazer o melhor que posso. Se soubesse voar... Eu fecharia os olhos e faria isso muitas vezes. (Ana dorme)

(As narradoras surgem, varrendo todo o cenário, inclusive Ana. Limpam todo o palco)

NARRADORA I - (Ao terminar) Acabou?

NARRADORA II - Acabou. 